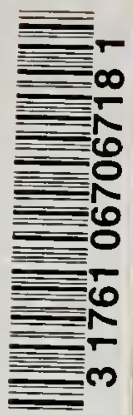

Godwin-Austin

Land and Freshwater Mollusca of India. Vol. 3 part I (text and plates) 


\title{
LAND AND RRESHWATER MOLLUSCA
}

\author{
OF \\ I N D I A,
}

INCLUDING

SOUTH ARABIA, BALUCHISTAN, AFGHANISTAN, KASHMIR, NEPAL, BURMAH; PEGU, TENASSERIM, MALAY PENINSULA, CEYLON, AND OTHER ISLANDS OF THE INDIAN OCEAN.

$-$

SUPPLEMENTARY TO MESSRS. THEOBALD AND HANLEY'S

CONCHOL,OGIA INDICA.

$\mathrm{BY}$

Lieut.-Colonel H. H. GODWIN-AUSTEN,

F.R.S., F.R.G.S., F.Z.S., \&c,

LATE DTPUTY SUPERINTENDENT TOPOCRAPHCAL SURVEY OF INDIA, IN CHARGE OF THẼ KHAST, GARO, AND NAGA-HILLS SURVEY PARTY.

VOL. III.

Fart I.-NOVEMBER 1920.

L O N D O N :

TAYIOR AND FRANCIS, RED LION COURT, FLEET STREET. 1920. 
Digitized by the Internet Archive in 2008 with funding from Microsoft Cốrporation 


\title{
LAND AND FRESHWATR MOLLUSCA
}

\author{
OF \\ I N D I A,
}

INCLUDING

SOUTH ARABIA, BALUCHISTAN, AFGHANISTAN, KASHMIR, NEPAL, BURMAH, PEGU, TENASSERIM, MALAY PENINSULA, CEYLON, AND OTHER ISLANDS OF THE INDIAN OCEAN.

\author{
SUPPLEMENTARY TO MESSRS. THEOBALD AND HANLEY'S \\ CONCHOLOGIA I NDICA.
}

BY

Lieut.-Colonel H. II. GODWIN-AUS'TEN, F.R.S., F.R.G.S., F.Z.S., \&c.,

LATE DEPUTY SUPERINTENDEN TOPOGRAPIICAL SURVEY OF INDIA, IN CHARGE QF TIL KIIASI, GARO, AYN NAGA-IHLLS SURVEY PARTY,

VOL. III.

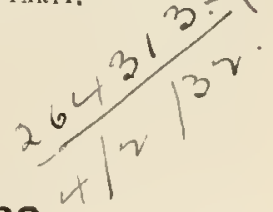

Part I.-NOVEMBER 1920.

LONDON:

TAYLOR AND FRANCLS, RED JION COUIT, FLEET STREET. 
5 


\title{
LAND AND FRESIIIATER IIOLLUSCA
}

\author{
वF \\ I $\mathrm{N} \mathrm{D} \mathrm{I} \mathrm{A.}$ \\ VOL. III.
}

Part I.-NOVEMBER 1920.

(Plites CLIX.-CLIT.)

\section{INTRODUETION.}

In spite of the rery limited interest which is taken in the aumals of the land mollusca, I am induced to comnence Volume IIl. of this work; for until the species in the many Uriental genera are collected, their anatomy made known, and thcir true habitat recurded, any attempt to use them for classification or any deuper research is not possible. The work of the Conchologist is simply useless unless this is done and the physical features of India are taken into account. During the war I have not been able to carry on this publication, begun 37 jears ago and ended in two volumes in 1914. On the other hand, I hare had leisure to do much with tho material in my hauds, and to add to it, aspecially specimens preserred in spirit, and have deseribed tho animals of mans Indian Genera previously unknown. I have had much support-mole than I had hoped to receire-and from many quarters : for this I cannot express roy thanks too strongly. I must esperially notice Dr. N. Anuandale, with Messrs. S. WV. Kemp and F. H. Grareley of the Indian Miseum. I feel it a duty to those who have supplied material, to put what I hare brutight to light on record, as a starting-point fur thuse who will follow me in this wide and difficult field of research, so full of deep interest to anjune who euters it.

PAlir I. 
I am most fortunate in having as a neiglihour Mr. J.S. Gladstone, an excellent and skilful photograplier. Without his ralued aid I could not gire the fignres of types and shells from trpical foralities, which show far better than any description the dircetion their suble differences take. For instance, liow distinctly photography whows the difference between $G$. trumispirm of Teria Ghat (I'lute ('LIX. fin. 33) and the species for long regarded as the same from Sikhiu (Flate (I,IS. ligs. 1 \& ״). Mr. (ilarlstone made fitotographs of 60 shells, which fill three l'lates. I may say liere, but for this gererous assistance, the pullication of this Honograju would not have been jossible. As an example of Zoologicial Iiesearch it las been met, and ly prirate means alone.

\section{Genus Gresscla.}

Wrule I hare been studying this genus, particularly the animal, as specimens were slowly obtained in spirit, knowledge of its taxonomy has increased. This has led me to look at many species very closely, for much had been left incomplete by Colonel Beddowe, jarticularly the species from the North-Eust Frontier of India, of which I possessed a rery fine series.

Some of this work on the genus Glrsulı might hare been pulished long agn in the second rolume of the "Fauna of British ludia'-some of it, anatomical, har been done ready for it: but I found 1 conld not, under the conditions in which I was expected to work, complete it in time. I had reached an age when extra correspondence was to he aroided, when independent tonchological work was pleasanter to do. It was nut to he expected I could place my collection at the serrice of others, neither could $I$ hasd over original work on the animals of the genus on which I had spent so much time and expense during many years. I could not grive the public the run of collections I liad deposited in the Natural History Museum under certain well-defined and rery reasonable conditions, reserring to myself the right to work on then during my lifetime.

At the end of Tol. II. (]. 435) I mentioned the genera I was engaged upon and trusted to deal with. Of there cilessula has been completed and is now presented in Part I. of this now rolume. 'The anatomy of sereral species has been made linown, and, when working out the collections madc when the pmitive expedition entered the Ahor conntry and the T'sanspu Valley (19) 1-12), I took the olylortunity of publishing the anatomy of a new species from Sikliim to elucidate that of the geims, as I dir not see at the time, with the war going on, any chance of publishing it at all. The animals of ofher genera have come to hand and hare becn rlescribed aud figured in the following 
order:- Imentmas and Opers (hoth rery well represented in ny collection), Sivellu, Harpalus, Mlunisprire, and Plectotropis (many species liave been worked out in these four genera).

Among the earlier writers on Glessela-l'feifter, Benson, and hoth Henry and William Blanford -Geoffrey Nesill undoubtedly has the hichest claim to notice; ho had made a special study ot the senus, and knew it better thin anyone I have come in contact with. Mnch of Beddome's knowledge was obtained from him in correspondence and exchange of specimens trom Southern India. This is well shown in his cops of the 'Hand-Lint,' being a cat alugue of all the Gasteropodit in the Indian JIuseum when lis health compelled him to retire. This is not a mere reprint: of the first original edition of 1878 containing 338 pages, lut there is added to every species the work in which it was uriginally published; all additional species (in this genus 2S) are giren with descriptions of those Nerill considered new, while in hundreds of cases throughout the book the dimensions of type shells are giren. Une point which nust not be forgotten is Nevill's great accuracy in the records of habitat and the collectors through whom the species were ohtained. The title-page is headed "I'roof for new Edition," "For the Trustees Indian Museur-G. Nevill, 1-11-81." On anotler page, "To bo offered to Trustces Indian Musenm if they consider it may be of any practical value to them; it not, to lie given to Col. Godwin-dusten. - Sigued, G. Nerill, Loudnn, July 5tl, 15.9." Shortly after Nerill's death at Daros in Switzerlam,, I received the copy with other books and raluable notes, and did all I could to get it published.

On $23 r d$ December, 1855, 1 first approached the Trustees of the lndian Muscum, strougly adrising the publication of a Second Fdition; in February 1586 I received a reply from the Henorary Secretary. Mr. H. B. Medlicott, ot which this is the conchuding paragraph: "The Trustees consent to your keeping present custody of and using the valuable copy of the Hand-list of Mollusca containing Mr. Nevill's notes and additions. There is no immediate prospect of special work in that branch of the collections." In fact, the post which Nevill held has never been filled up to this day: for to years the collections of Mollusca hare been in mauy liands, and in the course of many moves some species catalogued hy Nerill could not be found when I have applied for them. It says mucl for those who have had charge that the collection is not in a worse state.

I next took the book to Dr. John Anderson, the retired Superintendent of the India Museum, under whom Nevill had served. He conld effect nothing, although, if I remember right, ho went to the India Office: it was the old stery-no funds!

In Isss, in a tinal attempt to see it through the press mysclf, I obtained from Messrs. Taylor of Francis an estimate for 672 pages, 5 (n) cepies unhound, $\mathcal{L}_{22} \mathrm{I}$ 10s. 6 . This sum was not to he got-I had it not to gire, but would hare giren what knowledge I had towirds publication. 
Iluch has lately nppeared in the public press on "licsearch." If is of interest ti" put a case like this on record (if only to show how raluablo scientific work and linnwledge is lost for erer for want of (Govemment support.) To show how rescarch is ralued and rewarded, Ifuscums are built at an enormous known cost and filled with specimens at an onormous unknown cost; then a proper scientific Statf to deal with them is grudger, cxpenses are cut down, and the record is nerer utilized. In this instance Nerill lost the crelit which many years of closo study should have brought himnot among those he had worked with, hut among the general pullic. I an glat I have the opportunity ol hringing his labours to notice.

The liest account of the renus is to be tound in the "Manual of Concholngy, ser. 2, xx. 190s, commencing p. 50-the cxcelleut work of Di: Henry A. Pilslıry, with copious good illustritions, not only of the shells, but of the sculpture and of the embrymic apex. IIe sare (p. 52):- "From the purely conchological standpoint wo may be sain to have an extensive knorrledge of Glessula, yet various cluaracter's of the first importance have been neglected. The emlurymic whorts of the tipres must be all re-eramined, and their sculputue elescriberl. Our ignoranco of the embryonic seuphure of many forms prerents any natural classification of the succies. 'The surface of the later whorls in all the species should be examined under high power. since somo species have a minute sculpture not risible with an ordinary lens." Further on, lic ardes: "No matural classification of the spocies of Glessutu can be atterupted until the sculpture of the apices of the shells and the unatomy of a number of representative species are studichl." liearing this truly excellent advice in mind, I hare "ndearoured to follow it when describing the many species of the geuss now linown lrom the Eastern Frontior of [udia and Burma.

l'ilsbry* has given a good résumé of what has been done ir this genus and all that was known of tho anitomy at that tiue. For this last we are indebted to the rescarcl of I'rofessor C. Semper, who published, in his "lioisen iu Arehipel der Philippinen." 1s-3, p. 13:3, pl. xii. fige. 14-16 to pl. xvi. fig. 19, an anatomical descrijtion of Glessula aroplitu, Renson, said to hare come l'rom Madras, but it might have been collected in any part of Peninsular India.

It is unfortunate Semper's determination is open to doubt: we shall nerer know whether the shell of the animal he dissected was cosupared with the type of 13enson's oropluila, or what has become ol' that type deseribed by Recre. 'Ihe species is nut recorded in the 'Conchologia Indica, so Hanley nerer could bave suen it. There

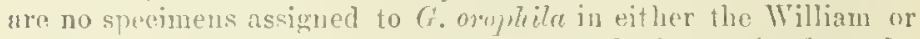
ILenry litanford collections. Beddome records the squeies from the Anammllay Ifils: Fouth C'mara: Golconda Ilills, east side of thu: Marlis l'resideney, and says, "My trolonda speeimens wero labeiled by II. Nevill (r. sublirezis, lut I canuot sec how they 
difler." Nevill, I think, only saw young oxamples ; Reere's figuro copiod by Sevill (i.e. G. Nevill), is good.

Geoftrey Nevill, in a paper on new or little-known Mollusea of the Indo-Malayan Fauna*, gives a description of the shell. He Irrites, under Stenogyra (Glessula) orophila, Benson MS.:"Reere, Concb. Icon. I850, fig. 105, antr. 7, long. 14 mill., as Acluatime oropteita, Nilgiris and Colombo; file Pfr., = his A. ceylanica. I give a copy of Roeve's original magnified figure of his $A$. oroptila, as I am by no means conrinced Dr. Pfeiffer is right in uniting it to his A.ceylanica; to judge from the figures, I shonld say they wero quite distinct species. It may bo that Reeve confused two distinct forms-the one figured (prolsably from the Nilgiris) a good and distinet specics, the other from Ceylon a nere variets of St. ceylunice which may have been sent or shown to Dr. Pfeiffer as A. orophile and caused him to unite the two species. I hare not myself seen any species of the gruml, St. nitens, cenlanice, menctogallane, etc., from Continental India."

Semper shows all the interesting details of the genitalia of his $G$. orophili, especially what he terms the flagellum, which is of very peculiar torm, elongate and comb-like, a character thus typical of the genus. It is, I consider, the sac in which the spermatophore is developer. In the teeth of the radula the shane of the marginals is not giren.

The genus, as recently as 1914, has been treated by Wr. G. K. Gude in the 'Fauna of British India.' He approached it with a great knomledge of conchology, bilnliography, and especially synonymy-the last most useful to workers, but nnattractive. Ther hare to thank Mr. Gude for mulertaking such labour. It shows, like so much work of its kind and of the series to which it belengs, that he had never been a collector in India and knew little of its physical features and all that that comprises. There is an absence of original matter, such as Dr. Jerdon, the Blanfords, Lydekker, Oites, Day, and others brought to hear on and emlellished the history of the Mammals, Birds, and Fishes of India which they had collected and which luad passed through their hands.

It is easy to find funlt, and it may appear I do so with Gude's work. I am only animated by the desire and stricing to make the record of Ceographical Distribution as correct as possible: thus under $G$. tenuispire, 1.379 . I notice all the errors of determination which lilanford, Theobald, Nevill, Bedıome, and mysulf hare perpetuated. I hare to point ont that theso determinations were made 40 to 60 years ago, much too long ago for such data to be reliable. I am able to say they were often marle mithout sufficient material at hand, or on shells erroneously ramerl in the first instance. I take, for eximple, G. baculinu, p. 37?, Khasi Hills (Goduin-Austen), evidently on the authority of Nevill in the "Hand-list, p. 170. It is a distinct species, which he did not notico; I have named 
it subluaculina, for 1 cunnot tind in uny collection from the Kilasi Hills any Gilessule that matehes the type in the Henry blanford collection.

\section{Classifuation and, Distritution.}

Mr. G. K. Gude, in the 'Fauma of British India,' puts Glessula into the family lertussacidie ( 1 . 373), immediately following the genera Cacelioules, type acicula, Miill., Geostillia, 1ỵo rmlelonica, Crosse, and balanus, Reove, together with a new sjucies, (1. bensoni (p). 375$)$.

With these gencra I camnot agree that Glessulu has affinity; the aniuals are nuknown, the shells rery different, the conditions of life and extent of range very distinct. Range is an important tictor in questions of this kind. C. acicula is l'alearclic, spreading to the far south. Glessula is Orientil and in comparison limited in its area of distribution. Commencing with southern India, it is ahsent from the $\mathrm{X}$. W. Himala!t, hordering on the eastern maruin of the Palenretic, cuming in (in Tepal?) in Sikhim and extending throngh the North-liast llimalaya, Assam with the Assim Range, and thence to Buma, Chinil, and sumatri. All theso are torest-clad countries with considerable rainfall, or country which was once much more torest-clad than at present, before man arriced to destroy the ancient forests. The Khasia Halls, with the Jijntia on the Fast. were once much more wooded than they are at present and formed a truct of country of great extent. Genst lhiu bulams, on the other hanl, may be callexl a desert species. standing great heat and great dryness fur nontlis. I knowledge of the animal wonlel be of cxtreme ralue in overy way. I camot find that it has evor been sien alise.

1 prefer to place Glessula and its suhgenera in a family of its owu, the Glessulidx.

Conchologically Glessulu posesses manr rery distinct characters. It eomprises shells which have the columellar margin abmotly trunciate at the base. Which in the majority of the species forms a short ratiter and holds a part of the mantle near the right dorsal margin. A well-lefinul disision wilh shells of all sizes is found liaviugr elongate, turreted, and Hat-sided shells, the major diameter dilleritg little from that of the small aperture. Typical Bucillun mesiuce tills under the above shell description. and i shall hise to rofor to this subgenus-it is much more solin and opapue, with stronger regular sculpture and larirer apex; the animal (1)ecomber $1919)$ still romains to he deseribel.

A departure from the Bucillum type of shell character is met with in Glessula temispira (Plate CLIX. fig. 3); the shell is thin, transparent, more or less finely striate, the aperture larger, and that and the body-whorl together are much larger than the shorter spire above.

This proportion of parts is intensified in species like Plate CLI. fig. 1 burrallensis, fig. 2 do.. fig. 3 do., fie. 4 do. fig. 5 sar. maxuelli : still more in fig. butlri, fig. 11 crassilatris, or what may be 
accepted as true Glessula. The animal of Glessula ochracea, G.-A., of silihirn, has been rissectel and puolished in "Records Indian ILusenu,' rol. viii. pt. xil. p. bil. It was found to agree with $G$. orophila as described by semper. Until maus of the smaller species are anatomically examined, thoy must all be placerl in Glessulic; the smallest species, such at $G$. gemma. maty possibly have characters of subgeneric value.

'The classification as giren in - Fanna British India,' vol. ii. (ville Systematic Index, p. x) requires moditication. Bacillum is placed in the Achatinide subtanily Stenoy!rince, whereas Glessulu is put in the Family Ferrusacida Genus 3. I can find rery litto ditierence between the animals of Glessula and Bucillum (January 1920), and consider the tirst should come next the other in the Stcnog!rinet.

Conch. Ind. p. 17, "the subgenus Bacillum is proposed by Mr. Theobald for this (A. obtusa, Btt.), the preceding (A. cussiaca, Bi.), and other allied forms."

It was lelt to Ur. Henry A. Pilsbry to describe the Genus conchologically, which he dues in Man. Conch. S.r. 22, xviii. 1906 , p. 1 , as follows. Ha mentious $t$ spocies and 1 sulsper.ies.

Bucillum.-." shell ratler large, solid, impertorate, turreted, many-whorled, a little contracted near the obtise, rounded summit; the enbryonic shell eylindric; sculpure of vertical rub-strice beginning somewhere upon the first whorl (l'i. fig. 12) : the postenbryonic whorls being oblipuely, regularly rub-striate. Aperture oblicue, Achatinoid, the eulumellar concave, truncate at the base, onter lip simple. Internal axis slender, strongly sigmoid within each whorl. Sott anatony unlsown.

"Tspe, B. cussincum. Distribution, Eastern India."

The very reent and extended knowledge of the animals of Buillum and Glessulu shows that the two genera come next each other: furlher, that the animals of tho latter present two rerp distinct divisions. This was first seen on dissecting a well-known species from Darjiling and Sikhim long knowu is G. tennispire in early Catalogues, such as Terill's 'Hand-list.' The specinens disscoted came from the lishetchu, a tributars of the Teesta, aud the anatomy is figured on Plate CIXT. figs. 1-1 c. On this 1 found a new Subrenus, with the following characters:-

Suligenus Rishetia, nov.

Shell large, thin, transparent, imperforate, turreted, manywhorled, tapering gradually to a rather aente embrjonic anes, first 2 whorls smooth; sculpture regular, rather coarse striation. Apertiro oblique, culumellar concare, truncate at base.

Animal. Urotestis tightly couruluted, close to the albumen gland. Prostate and oriduct compact cylindrict, with closelypacked fullicles. Spermatheca large on long duct. Penis with a distinct simple gland or fligellum retractor unscle on side.

It is also apparent, with the gradually accumulating knomledge of the animal combined with form of the shell, the genus Glessula adnits of subdivision-Glessula as a subgenus to include all those 
species possessing the enmb-like nprendage to the penis (flagellum). Infortunately, up to date 19I9 the anima! of a true Bacillum has nerer heen obtained, never eren scen alive. Still I am inchined to think this genus comes in close to Glessuhe, in faet far eloser than does Curvellu or Ilarpulus. The comb-like flagelhum (P'. CLAXV. fig. $2 c$ ) is replaced hy at short, pointed, simple one (Pl. CLXV. tin. 1 a), while in a (eylon species it is massive, with an indistinetly tripartite outliue (I'. CLXV. tig. $7 a, f$.).

Distribution.--The absence of Glessula in the North-llest Flimalaya and the Punjab is rory remarkable, riz. from all the old ralleys of the Punjab Rivers and the Ganges. Whether this featuro extends to the Kali liver and through Nepal to its easteru boundary, the ralley of the Tambur, which Nir Joseph Hooker w:ts the first to explore and describe, has to be diseorered when that country becomes better kwown and is collected in.

The only exception to the abore distribution is the reported oceurrence of one species, $G$. huyti l'lir. in Kashmir. I harenerer seen or heard of its being foum there; I was always collecting, and $n \mathrm{n}$ man in my time saw so much of Kashmir Territory than I did. I am inchued to be sceptical, for Kashmir has hecu fairly collected in by zoologists such as Noliczka and Thenbald, who were not likely to miss finding so large and conspicnons a shell, $37 \mathrm{~mm}$. in length.

Yr. Gude says (p. 357):-- "When first deserihed, its origin was unknown. Kaslimir was lirst given as its habitat by Ilanley. and Theobald. The speeies is allied to Glessula chessoni, but more solid in texture. The Cuming Collection contains threw speeimens from kashmir, with a label in l'feiffer's hand-writing."

It is, malcorer, on the authority of Hanley and Theoball, Conch. Indiea, p. 33; this means "Hanley," who had little regarl for Geographicil distribution. I saw a good deal of IIanley" about 1869. He never grasped the enormous size of India: how different is tho elimate on its nurth and south, its rast jlains and mountains. Consequently I am led to think. "u learning that ron II iigel had risited Kashmir, any shell connected with him Hanley assumed from that part of India.

With Eastern Nepal a great ehange talies place in the orograjhy of the Himalays; the nost elerated jeaks, Mt. Ererest among thom, lie parallel to the plains at abont so miles distant, and a chain glaciated and corcred with snow is contimons for 500 mill.' as far as the Kali Ricer. This must affect, cren at the prestnt da!, the temperatue of the ralleys draining to the phains, and surely would hare sufficed during the flacial period to limit the Innil Vollusea to the base of the hills, from which many species would nerer hare returned or surrived the change. It produced conditions thus far to the liast similnr, but on a small scale, to the disturhance of the fanua and flora in Europe caused by intense cold. Procerding to the N.W. to the latitude of Kashmir, these conditions wonld hare been intensified, for enormous glaciers 40 miles long nnee filled the main valley's.

The genus ranges all orer l'uinsular India, is more abundant 
in the South, extending to ('eylon, a fur speries being fonmi common on both sides. It has been studied by H. A. Pilslury, who cites 58 species; G. K. Gude, in Faun. I3rit. India, raised tho number to 80 ; Colonel Ii. H. lierldome (1906) gives 5:3; while Nerill in his Proot Copy 'Hand-list' (1881) records 15.

The species are very distinet; none are found outside the Peninsula, as fur as $\mathrm{my}$ in restigations go, and $\mathrm{l}$ hare been able to correct several incorrect determinations.

The sulgrenus lismptia dous not extend to South India, apparently. Beddome has recorled $h$. timmisprire from North Canara, bised ouly on a single specimen withont any history : sec what I say of this uuder the title of Tongisprira No. 2, Silihim and the 'Teesta valley.

Going back in time, it has not been recorded from tho Intertrappean beds of the Peninsula-tlose of Nagpur, for instance; but I see no reason why it should not be fonnd in them, esprecially the smaller species, and it should be looked for. We do not half know the genera presorved in this old formation*. The lier. Stephen Hislop, in the 'l'roccedings' of the Geological Society, 1559, p. 154, deseribes the "Tertiary Dejosits associated with Trap-liock in the East Indies," and the fossil shells are described and figured liy him. Having rery recently received througb Ir. N. Annandale a collection of these fossils from Nagpur, I have been led to read the paper. An interesting paragriph I quote from is on p. 164:- - I have shawn my freehwater sholls to Mr. Renson, the highest anthority on the Mlolluses of our Indian lakes, and he gires it as his opinion that not one of the specimens subritted to him exactly corresponds to any thing he has scen." 'This was written 60 Jears ago; it is in accordanco with my conclusions expressed in a letter to Dr. Annandale dated 3ist March, 1920: "I have had an hour's look at them, and can saj they are all unknown forms to me." 'This rich funna of [pper Cretaceous age should no longer lie thos neglecterl, for since Hislop wrote an enornous adrance has been made in our knowledge and treatment of the Land and Freshwiter Mollusea.

"l'he Zoological Results of the Abor Expedition, 19I1-12." published in the "Records Indian Museum,' rol. viii., have considerably modified our idens of distrihution and terl to the records of the pisst (nearly forgotten) being looked up. It points to a migration of mollusan life from the far South. Perhaps no more interesting history can he recalled than my finding on Shengorh l'cak, To00 feet. in the Ditfa IIills, a species I named and deserihed as Stafforlin daflaensis, Moll. Ind. pt. x. April 1907, 1. 184, pl. exiii. In expectition of receiving other material, I did not refor to $m y$ rescription of Diakice striate, var., from Sian, in Proc. Malacolog. Societ5, rol. rii. pt. "2. p. 93, pl. x. June 1906. There is no doulit.

* In a paper on some Freshirater Fossils from Central South Africa (Annals \& Mag. Nat. Hist.. vol. v. Mareh 1920) Mr. R. Bullen Newton on p. 246 refers to certain species in the Nagpur beds. N/so my contribution in "Records of two Indian Museums" 1919, Oct. vol. xvi. pt. vi. on the genus Mysorellu of Sunthern Indir, pointing out the necessuty for their generic revision. 
as to the close relitionship, especially shown in the genitalia. Dickia did not oceur among the Abor eollections, unless it shall evontually turn out that Bensonia (?) aborensis, Ree. Ind. Itus. rol. viii. p. 596 (text-fig. 1), has similar anatomy. In shell eharacter it is mulike that of any Indian Genus 1 haro seen; but 1 har ouly one spucimen to deal with.

For a knowlerlge of the peenliar anatomy of Dialia, we have to go to Semper, where he deals with what was then known as

Ariveluanta rmmphii in lieisen, pl. iii. tig. 18.

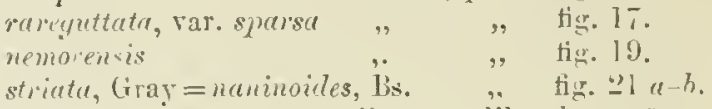

He gires heautiml tigures of the genitalia, so unlike thuse of any strictly Indian Genus.

Gur knowlodge of the Assam Land Mollusea is rery imperfect; much has still to be done, with smiall chance of our linowing more nuder present. eonditions. In fact, discovery of specjes of great interest is sheer luck; unless 1 he conditions are exceedingly good, perfect $\mathrm{i}: \mathrm{l}$ l'act, nothing is found. To exemplify this, 1 will gire an experience of $m y$ own when in the Ditta IIills.

shengorh Peak was one of my Trignnometrieal Stations, and I had to clcar the forest before I could eommence obscrvations. liain set in soon after piteling camp; so l had plenty of leisure to eullect in Natural Ifistory. The wet bronght out the shells and slug-like forms, and 1 had a busr time making drawings and takiner motes of colour and size. I secrired what in drier weather I shonld nerer have got, certainly not alive; anong them was this unique Gienus Staffurdin, whose mearest relatire linown to us is found at Chantaboou in Niam. It doubtless occurs at many intermediate places which have yet to be discorered, wheld its possible ancient conuection with Assim may be explained.

This is the histnry of a visit to une high point, one which orerlonked the great hroad ralley of the subasiri, extending fir basck to the tase of the snowy range, away to hundreds of peals corcred with primeral torest. The imagination fuils to picturo what the result of exploration would be, combined with knowledge of how :m wl wat to eullect. In these solitudes Xature reigns supreme: onc dues not viten find such a spot-seldom risited hy man, never lised in by lim.

The birds on this Peak were fearless. I was yuite struck by the lehaviour of a bealutiful little suthora. Which kept horering about my lead and woukl perch on a twicr a yard from my face.

Ftarting with silihim and the valley of the leesta, where speeics are numerons, I trike in succession going castward the great ralleys of the Fastern Himalaya to the Brahmajutra, they go tar back in geological time-are older, in fact, than the siraliks, lor down their courses all the waste of the Ifimalnya has passed either to the sea, as in the case of the Teesta, or to huilil ap the aboretomation. 'The rast thickness of these 'ertiary rorks, originally deposited not fur ahre sea-lerul, the basement beils leing even marine. as near Sumaguting, is well seen on the Assam liange south of the Brahwa- 
jutra, where they are clevated to 10,0100 feet in the Patkai and Naga Hills. In the Garo Hills this dimishes to 3000 feet, lut they are there in force with a thickuess of some $5000-6000$ feet: vide 'Jourual Asiatic Society of Bengal,' vol. xxxriii. pt. 2, no. 1, 1869, with a Goological Nap of a portion of the Khasi Hills near longitude $9 \mathrm{~J}^{\circ} \mathrm{F}$.

Connected with this range of the genus, two facts stand out:(1) The extreme age of the great valleys; (2) the great difference between the Jlolluscan fauna of Sikhim and that of the Datla Hills, still more when it is compared with that of the Arbor country. 'luere are rery few species common to hoth. Few sikhim species are found in either: all is new, even new gelera come in. 'The reason for this is no doubt due to the physical features of the great valleys: some, sueh as the Monass and Snbansiri, are rery lroad; they go back far into the lange; their sources glacial, they are separated one from the other by lufty snow-covered longitudinal ranges, which continue high to the plains. They are thus completely isolited onc from the other, allowing evolution to go on independently within them and folm "specific centres."

The rich flora and filuna of Sikhim is in direct relationship to its position at the lead of the bia of Bengill, and for ages has received accessions from that, the Suuthcru side; so with species of Glessula, when those at present living between the l'eesta and the Monass are comprared with those of the Khasi and Garo Hills, 100 miles to the south, how small and yet how defined is the difference.

Himalaya area :
longispina.
hastulu.
baculiua.
tenuispira.
sublectustule.
sub-baculina.

Represeuted in the Klısi-Garo area:

Between these two areas there is an indication of a once more continnons land-surface higher that at present. All this delta area has gone through consideralle depression with denudation. This is so well exemplified by the isolated, weathered masses of intrusive granite rising abruptly ont of the allurium by which they are surounded at Chanda Dinga, opposite Gwalpara and Doobri. II furvey work took me to the top of sereral such hills. Granite intrusion is frequently seen; it is to be noted at 'Tura aud Riwuk on the Assam liange, and similar intrusions oecur further east and north intimately connected with the forces of uphearal. Those near Gralpara, on the north side of the lirahmaputra, no doubt originally jassed up and through stratified rocks long since denuded (jerhajs of Cretaceous age) which cover so large an area in the Garo Hills, where they have also suffered great deundation.

Tumbers, followed by the letters B.MI., refer to specimens catalngued in three collectiona presenter to the Britisls JJuseun, viz. thase of 1. W. T. Blaufned and H. F. Blantord combined, 2. Colonel H. Beddome. :3. (fodwin-Ansten; they cannot fail to assist those who mily study this group or liare to name specimens from India. 
1. North-TJest Ifimulu!u, (No spreies as get found).

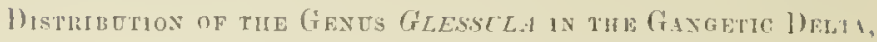
Nortil Eist Frontrer of livia, axo lierma.

2. Silhim and the Teesta Falley, with Western Bhutan, including the Delta.

$$
\text { Long. } \$ 3^{\circ} \text { to } \$ 9^{\circ} \text { East. }
$$

\begin{tabular}{|c|c|c|}
\hline eserte, hishetine be & 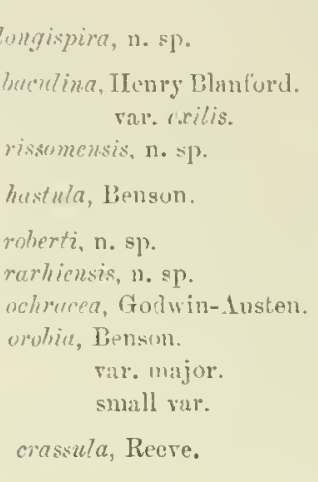 & 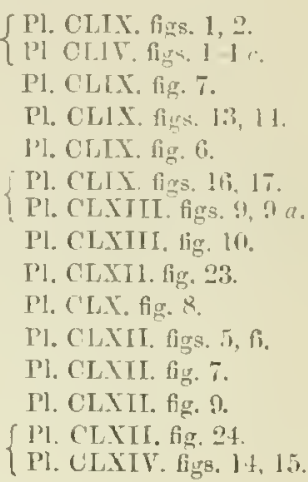 \\
\hline
\end{tabular}

From the Delta.

Glessula sarrissa, Bs.

Pl. CLXII. fig. 10.

genma, Bs.

P1. CLX1. figs. 2h, 27, 28, 29.

var. minuta, G.-A.

Glessula (Rishetia) loxgrspiri, n. sp. (Plate CIIX. figs. 1, 2 , shells: Plate CLXV. figs. 1- I c, anatomy.) No. 5.5z L.Al.

Locality. Risett Chu, Sikhim (Wm. Robert).

Shell elongately turreted; sculpture: line, regular and rather coarse striation; colour rudily uchraceons; spire very lone, sides straight, apex attenuate: suture shallow; whorls $1: 3$, siles that, juropurtion of length to last whorl ]uU: :34; aperture small, oral; jeristome thin; columellar marrin slightly couvex.

Nize: maj. liam. 95: lengtl $44 \mathrm{~mm}$.

In the blanford collection ( $\mathrm{T} 0$ 2.35.06.2.2) one specimen measured $47.5 \mathrm{~mm}$. in length, and is the largest 1 have seen.

Shell of animal dissected $40 \times 9 \frac{1}{2} \mathrm{~mm}$. ; whorls 13 (No. 5.5.) B. II.).

The generative organs (Pl. CLNV. figs. $1 a, 17$ ).-These are naturally rery elongate and twisted: the hermajhrodite duct is long and closely eoiled. 'The albumen gland clongately oval, uterus and oriduct very long, compact, cylindrical, the oviduct showing broad, elose eouvolutions (tollicles). The penis is a simple slieath, 
with the ras deferens given ofl' at the extreme distal end, close to the sland $(f)$ which represents the flagellum. In the second specimen dissected this is well shown (fig. 1 b); it is small, short, slight]! hooked, not that and notehed as in $G$. ochraceu. Further on, in a species from ('achar: a small rariety of $G$. yoroense (turreted and elongate) a similar short flagellum was found (Plate CIXY. tig. (i). The spermatheca (sp.) is an elongate sac on a long stalk. The retractor nusele is giren oft about halt-way down the side of the sheath.

The anima] (fig. 1) can witlıdraw into the shell as far back as the three last whorls. The sole of the font is widely segmented fiom side to sile. Contracted in spirits the animal has abont s whorls (fig. 1 c). There are nurrow right and left dorsal lobes, and on the columellar side a muscular cylindrical mass fills tho characteristic groore.

\section{Glessora losgispirs, 11. sp. (Plate CLIX. fig. 2.)}

Locality. Rartichu, Sikhim (IT. Rubert). No. 3593 R.M.

Animal. Foot short, rich grey black, surface minutely papi]late, in strong cuntrast with the sole, which is pale ocbraceous, warrowly serrinented transrersely.

length to last whord 100 : 39.

The jaw is slightly conrex, very thin and transparent, and under ligh power is seen to be made up of rery uuncrous narrow elongate plates.

Nize : length 37 ; m:1j. diam. $8.75 \mathrm{~mm}$.

From the licchila Peik on Sikhim border and Testern Bhutan. Mr. Wm. Kobert sent me fire specimens (Nu. 28 I.MI.), sepialrown in colour, and with far stronger seulpture, which may he ronsidered a local variety. The largest has 12 whoris, aud ineasures $37.75 \times 9.65 \mathrm{~mm}$.

Anatomical inrestigation shows that there are two rery distinct sections of Glessulu, and so fur they conform to shell character-for how great conchologically is the difference between the turreted very long species and the glossy, oblong-conoid forms? The short oflong species, such as $G$. gemma, have yet to be examined-they mal bave some character of their own, viewed anatomically.

In this genus and this particular species it may le said I am laying considerable, eren undue stress, on rariation in a single organ-the jenis - anl of that only a purt. This will be noted and felt eren more by conchologists, some explanation therefore seems necessary for entering into physiological details. The flagellum is a very small organ. but one of great importance; in the derelopmental life of the animal it has a most important part to play. Within it is formed the spermatophore, which is flled with spermatozoon, and eventually, in the act of copulation, is transferced to the spermatheea of the other indirilual-its spines kep it in position on its passinge and retain it there. In clifle'ent gentra, it takes on more or less very complicated toms am bromes a very important character. 
oftcu far morc easily described than the shell itself. In the Sonth Atrican genera, Peliatus and Kerlophorus, it is a beautiful onject in the micrnseope.

['nder Gilessula tenuispira, Benson, Co]onel Beddome in his notes on Indian ard Ceylonese species of Cilessul" in the "J'rocecdings of the Italacological Society of London,' rol. rii., Sept. 1sur, p. Ifio, says: "Tull grown oncs collecterl in the Teesta Valley near J)irjiling and in Forth Canara measuro $44 \mathrm{~mm}$. in lengrti (virle Phate (hIX. fig. I) and have funrteen whorls." The single example recorded from N. Canara is now in the Nitural Hixtory Iluseum and is hefore me. This is a prart of India which was well known to Colonel Berldome-in fact, where lis work as head of the Forest Department lay. It is noticmale there sliould be no listory, mo remark on tho very remarkable occurrence of this species in Southern India, and that only a single specimen was seevred. Until it is rediscovered vers considerable doubt must attach to the accuracy of the habitat. The specimen may even have beeu purchased.

Guessola canaraensis, 11. sp. (Plate Clix. fig. 8.) No. 681 Bedd. Coll B.Mr.

Lnculity. N. Canara, collector unknown. (A single speeimen, if found again.)

Shell elongatels turreted; sculpture: irregular fine striation; eolour pale ochraceous; spire long, apex rather blunt, romderl: suture impressed, very slinhtly uotched on lower margin by the striation; whorls 14, flatly convex; npertire ublique, ovate; columellar margin slightly concare, truncate below.

Nize: maj. diam. 8.5 ; longth $41.25 \mathrm{~mm}$.

Atter very careful comparison with all the specimens in the Blanford and my own collection, I believe this to be a fine, more attenuate example of G. longispira, and that it really cante from the neighbourhood of Darjiling. It is a single specinen, and its jresence in Southern India has to be confirmed and the animal examined.

Glessela mactuma, H. F. Blanford, No. 9-9.iii.15 B.M. (Plato (LIX. fig. 7.)

J. А. ร. B. xl. $18 \pi 1$, p. 43, pl. ii. fig. 6.

Oririnal description:- Testa elougato-turita, gracilis, tenuiscula. oblique striatu, fusco vel fulvo cornea, epidermide witescure imluta. Sjpira turrita, apice abtusult. Antoactus 13, parum comereri inferiores subaruales; sutwa impressa, minute denticulatu. Aproture blliqua, outo-triangularis; peristoma simplex, actum. ('olumella abripte areuata, oblique producta, ad basin verticalite. truncuta.

"Alt. $35 \mathrm{~mm}$; diam. $\{5-57 \cdot 5 \mathrm{~mm}$. : aperture alt. 7. lat. $4 \mathrm{~mm}$. "Copit Dr. F. Stoliczla ajul Kliersong Ilinalaye Silkimensis. 
"This species appcars to lave escaped the notice of all previons collectors in rikim; it was found in assoeiation witl its near ally G. tenuisprira, Bens., by Dr. Stoliczka during a receut visit. It is easily dosinguislued from the latter species by its slenderness (the diameter beiug $\frac{2}{6}$ of the length), and the complarative narrowness of its whorls ; moreover, by the form of the columella, the low er pirt of which is bent abruptly almost at right andoles with the slope of the inner lip : while in $G$. temusprim, $G$. erosu, and other allied forms, the curvature is at the utmust ubtuse. Specimens, the shell of which had been slightly weathered, slow fint spiral markings, but these are not risible unless the shell has become somewhat opratue. 'The animal is dark leaden grey', somewhat paler at the sides ol the foot.

"The fullowing is a list of the species now known from Sikhim :G. temisprive, Bens., G. crassula, Bens., G. hustula, Bens., G. orobiu, Bens., G'. erosa, nob., G. baculina, noh."

When goiner through Hewry Blanford's collection, bequeathed to the British Musenn by his brother, I came on the type specimens of the abore species: these $I$ had not seen for 46 jears. At the time I was staying with bim in Calcutta, he placed them in my hands to figure for a priper he was preparing for the Asiatic Society of Bengal, vol. xl. pt. 2, $1871, p .34 \%$ It is a rery distinct species. I hare quite a large series obtained since from different localities in Siklin and Western bhutan. Buddome (Pro. Malacol. Soe. $19(16)$, in his paper on the crenus, conmilers it only a more slender form of tr. truispira, Is., a ricw most diflieult to fall in with and support. There is a rery considerable difference in general formthat is. when compared with the so-called tenuispira of Sililim. Mr. Gude eredits me with hasing fomd it in the Khasi Hills (F. B. Ind. ii. p. 379), probah? on the authority of Geoffrey Terill, in his Haud-list, p. FT0. The Kllasi form is quite distinct and deseribed further on.

in the Beddome collection put up in the same box are fonr shells under this name, with two labels in Beddome's landwriting. One luas on it (three in pencil) "Darjiling, H. F. B1.," the otluer (one in pencil) "Thret Mro." It is easy to see the difference in this last from the others, the apex is much more attenuate, the aperture larger and broader. The Darjiling sbells are quite typical, and I bavo compred them with Henry lilanford's types.

$G$. bacelina was found by Mr. Wm. Robert at Zemo Samdong in Sikhim, some 60 miles up the Silinim Talley-there smaller, $2 s \times 6.25 \mathrm{~mm}$. (No. 553 B.II.)

Glessola (lishetia) Bacolina, H. Blf. rar. exilis. (Plate CLIX. tigs. I3, 14.)

Locality. Rissom Peak, Sikhim (3595 b.M.)-Type. Damsang, Sikhim (35y4) (II. lobert).

Shell elongately turreted; sculpture: rather close rilised striation, oblique; colour umber-brown; spire long, apex fine, 
first three whorls nearly same diameter; sut ure impressed : wherls 12. flatly convex, body whorl and aperture $\frac{1}{3}$ of total length: aphrture ovate, small; peristome thin; columella sharply curred, truncate.

Size (Damsang) : maj. diam. 5.5; length $24.75 \mathrm{~mm}$.
(Ristom):
$5 \cdot 7$
$36 \cdot 00$,

This is close to $G$. baculina, but the whorls are not so flat as in thit species, and it is rery much smaller.

(ilgseda (Rrsiletra) rissnumsis, n. sp. (J'late CLIX. fig. 6 of a Damsang shell.) No.35\% B.M.

Lacality. Rissom Peak and Damsang, east of the T'eesta Valley (11. Robert).

Shell elongately turreted; seulpture: close irregular striation IW.1! marked; eolour dull white with a pale ochre tint; spire: apex blunt and rounded, sides nearly straight : suture impressed; whorls 10, the embryonie linge and ronmenl smooth, sides tlatly monvex; aperture evate; outer lip with a good deal of conrexity; (w) mellar margin very silghtly eonvex.

size (Rissom Peak): maj. diam. 6.25 ; alt. axis 24.5 mm.

I liaro this preserved in spirit; the animal is pale colonred throughout. The specimens are not fully grown, the larger ipex distinguishes it at once from $G$. laculina. It approarhes (r. humuttiensis of the l)afla 11 ills, but the apex of that shell is finer, the embryonie whorls being closer together. Specimens were also obtained on Rissom reak.

Glessula (Rismetia) hastela, Benson. (\$SO.06.1.1.) (Plate CI.XI. fir. 16); (No. 16.9.iii.15 13.M.) (Plate CLXI. fig. 17); (for apex enlarged, Plate CLXIII. figs. 9, $9 a, 10$.

Achatina hastula, Benson, A. M. N. H. sor. 3, vol. 5 (I860) p. 461.

Original description:- "Testa turrito-subulate, temu, oblipue crepilluceo-striata, fusco-cornea, niivlula; spiru subulreta, apice obtuso, snture profundiuscule; anfractibus 9, primis converis, postremis rosvexinsculis, zultimo $\frac{2}{7}$ teste atlingente; apertura vix oblique, orato-elliptica, peristomatis marginibus callo, temi junctis, deatrati recto acuto columellari arcuato calloso albido, basi oblique truneata.

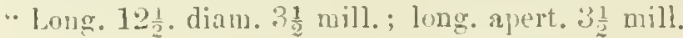
likant.

"Habitat ad Paukabari, prope Darjiling, raro. T'este W. T.

"()f a more slender form than the large Ach, temispira, B., the whorls increasing very gradually, and not attenuate towards the uper part of the spire as in that speeies."

This spreeies was oriciually found by $\mathbb{W}$. T. Blanford at Punkabari at tho foot of the Darjiling IIills.

1t has been recorted hy Theohald and Stuliezla als oeeurring in Burna, Kumah Hill and Maii, Sandway District, Arakan (repeated 
by Gude in Fauna B. India, rol. ii. p. 41t). In a paper hy them in the Journal of the Asiatic Society of Bengal (rol. xli. Is:-2, p. 341 ) they say: "somewhat larger than the sikhintype shell." 'This record is of little rilue, when one considers how cursorily some sliells, particularly of cilessulu, hare becn looked at aud how little time is often bestowed upon tlem. Terill in lis Hancl-list, p. 169, only gives the Darjiling locality. 'Theobald, it would nppear, nerer gave specimens to the Calentfi IInseum, and it inpossible to say where tlese shells of his went to.

In IV. 'T. Blantord's collection is a single typieal specimen (No.880.06.J.1), and on a label in IIanley's handwriting a noto "Identical with the large one figured in the Conch. Indica" (Plate XYIII. fig. 4). Tro specimens were in the Henry Blanford collection which nay be considered also typical, as the two brothers were constantly exchanging specinens.

I find Glessula hastula, Bs., does not extend to the Garo and Khasi Hill ranges, its place being taken by a shell at first sight rery similar to it, but which on close examination is found to differ sufficiently to describe, maling it all the more improbable that $G$. hastulu exteuds to Arikan. G'. lustulu of Darjiling is more attenuate with more costuliate sculpture than in the Khas form.

Apex enlarged of (\$80.06.1.1 13.M.) Plate CLA111. tigs. y, 9 ", Darjiling, and of (55- B.Ml.) tig. 10. Ricliila.

It may be noted that the ales ol the last differs rely much from that of a typical lecestulu, a grood character and sufficiont to create a species which I name aftel. Mr. W. Iiobert, late of the Indian Furver, who marle for me such a splendid collection when he wis worling in sikdim. There are only two speeimens and one other from libsom Peak (No. 2t83 B.M.). It is rery possible uther examples will be tound among my spirit-speeimens.

Glesstla (Tishetia) roberti, n. sp.

Locality. Richila Peals, Testern Bhntan (No. 557 B.М.)-Ty]e. lissom l'eak, Sililim (No. 2483 B. I.) ( J]'. Robert).

Shell subulately turreted; sculpturo: very regular, close wellraised striation, commencing on apex (Plate CLXIII. fig. 10); colour ehestnut-brown; spire elongate, side flattened, ajex blunt, rounded; suture slightly impressed; whorls $8 \frac{1}{2}$, very regularly increasing, sides flatly conrex; aperture small, orate; columellar nuargin concare.

Size: maj. diam. 3.5 ; alt. axis $11 \mathrm{~mm}$.

\section{('Lesstla rarmiexsis, n. s]). (Plate CLǎli. fig. 23.)}

Locality. Jarhiclu Valley, Sikhim (10 specimens) (No. 33:35 B.ML.) ( $\dot{t} \dot{r}$. Rubut).

Slucll elongately conical, sling; sculpture: distant irregular strice: coluur dark nmber-hrown; spire higl, sides Hattish, apex blunt; suture impressed; whorls $s$, Hatly convex, rather regular

PATIT I. 
in size, i.e., increasing rery gradually; aperture narrowly oral; columellar margin very slightly convex.

Nize: maj. diam. $4 \cdot 0$; alt, axis $11.20 \mathrm{~mm}$.

This is more elongate than $G$. crassula, but similar in coloration and seulpture. It is certainly more than a variety of the Darjiling shell.

In Wm. Blanford's collection is a single specimen, which I refer to this species, found by him on the Chola range at $11,000 \mathrm{ft}$.

\section{Glessula ochrace., Godwin-1usten. (Plate CLI. fig. 8.)}

liecords Indian Museum, rol. riii. pt. xii. p. 617, 1918, fig. ix. A.B.C. (genitalia).

Locality. Rarhichu, Sikhin. T⿰̣pe. (No. 3592 B.II.) Richila Peak, rar. (No. 555 B.Mr.) (II'. Robert).

Shell conically turreted and tongate, solid, smooth, and slining: sculjture: very regular sharp striation: colour dark rich ochre, a paler margin to the peristone; spire high, sides slightly conrex, apex blunt: suture impressed: whorls $7 \frac{1}{2}$, flatly eonrex, the last tumid; aperture oral; peristome $\pi \mathrm{cll}$ thickened; columellar margin strong, eurved, noteh at base deep.

Size: maj. diam. 9.25; length $21 \cdot 25 \mathrm{~mm}$.

Animal (Plate CLIV. fig. '2A). With short fout, the sole of which has a central groore cach side closely segmented.

The buccal mass (Plate CLXY. fig. 2 B) is globose and small with a very strong retractor muscle; the salicary gland is in a single bilobed mass, one side long and pointed.

In the generatire organs (1'late CLXT. tig. 2c) the hermajhrodite duct is conspicuous by its size, is very long and strongly and closely conroluted. 'The albumen gland is rerr globose. The uterus and closely consoluted oriduct slort. The penis is a folder sheatl, and what I take to represent the flagellum is a flattened mass, straight on one side, luaring a serrate elge on the otluer, consisting of a short terninal and ten longer notches, very characteristic and umusual in form. A similar flagellum is met with in orophitu, Bs, as tigured by Professor semper (Reis. Archipel. $187: 3$, p. 133, Taf. xil. figs. 14-16, under Cionellu) there is one terminal and 30 notehes, ciring it a feather-like form. The ras deferens joins the penis close to this at the distal end. base.

The spermatheca is oblong, rather short, ou a short thicks

Glesscla ochracea, G.-A, rar.

Locatity. Rielila Peak ( 11 . liobert).

Is larger and a much darker ochre than the tỵe.

Iaj. diam. 10 ; lewgth $24.05 \mathrm{~mm}$. 
Glassul orobia, Iis. (No, 17.9.iii.1, li.M.) (Plate CT.TII. figs, 5, 6; Plate CLIIII. fig. t, apex of No. 17; Plate CLXI. figs. $4-4 b$, genitalia).

Achatina orobin, B. A. M. N. H. ser. 3, r. p. 461 (ISSO).

Locrlity. Senchal and Darjiling.

Oriminal description:- "Testu ouate-oblonga, solielinsenla. leergata, leviter striata, strie non-nullis remotiuscnlis profunde impress is

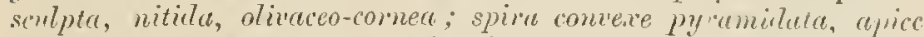
obtuso, suture impressa; anfiractihus $6 \frac{1}{2}-7 \frac{1}{2}$ covererinsculis, ad lume:um angulatis, crenulatis, ultimo $\frac{1}{3}$ testep superunte; aproture

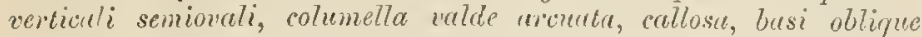
trimcatu, peristomate recto, crassiusculo, obtuso.

"long. I1, diam. 5 mill.; apert. 4 mill. Jonga, 3 lata.

"Habitat ad Sinchul et 1)arjiling (alt. ped, 8500 et 7000 ). Teste W. T. Blanford.

"Distinguished from the larger Khasia species, A. crassilulwis. B., by its peculiar sculpture, and by the formation of the whorls below the suture."

'The specimen figures is from IIy. Mlanfort's eollection No. 17, 9.iii. I5, and measures $11.05 \times 5$ mm. There are tiro othel examples, and in another box (No. 243, 06.2.2 3..1l.) are four others all alike and from llarjiling.

Mr. Gude, in 'Fauna British Indin, Mollusen,' ii, InIt, says: "Some specinens in the Beddome collection from the Naga Hills, composed of $6 \frac{1}{2}$ whorls, measure $8 \times 3 \%$ um., and refers to another shell also from the same lecality, possessing only six whorls, with rather eonxex sides. measuring $6.5 \times 3 \mathrm{~mm}$." I have now seen these (No. Tthe of iny cattilogue of the shells selected out of tho Buddome eollection). They are Glessulu prowiensis, mihi, and very dilferent in every way. 'The apex of one is given on Plate CLXIII. fig. 1 ; also that of $G$. orotia from the IIenry blanford collection, Ni. 17, fig. 8.

Glessula ozomia, 13s, rar, MaJor. (Plate CLXJI. fig. T.)

lichila Peak, Sikhim. Trpe. (No. 556 D M.)

Damsang, Nikhim. (No, Mi33ti.)

This is a much largor shell, yet has all the characters of the Darjiling examples in its general form and increase of the whorls. It is, however, a dark umber-lorown, and in this resnoct is like cressule from the same peak. which is a much smaller shelf.

Var. majur measures: maj. diam. 5.2, length 130 mm.

Gressti orobil, var. M.AJor. (To, 5;6 B.AI.) Dimsang, Silihim. (Plate CLXV. lig. t.)

The generative organs were seen complete and proved of great interest. The anpendace giren oft "nwr the junction of the vas defereus at head of the penis is small and land-shaped; it consists 
of finger-like lobes, one short, and three united together longer (figs. $t a$ an $]+b)$. It represents iu a shorter form the sume appendage in $G$. ochura, in which there is one short and ten comb-like notclues, unt the still longer one as renresented by Semper in (i. orophilu. which has led to its being described as a fcather-like gland and tyiseal of the genus; a better linowledge of the animals shows it will only apply to a section of the genus. The elongate forms cerfainly form another, and may possibly hare to be included in Bacillum.

The prostate (lig. 1 ) is round, short, and solid; the hermaplyodite duct, much convoluted and thickened, loming a mass close to the albumen gland. The tecth of the radula do not differ from those ot other species dissected. The formula is

$$
\text { or } \quad 16.4 \div 1 \cdot 9.16
$$

firkssuld oromia, lis., smull rar. (Plate CLXII. dig. 9.)

Locality. lichila leak, Western District. (No. 559 13.1l.) (II. Robert).

Shell elongately conical, shining, somewhat tumid; sculpture: irreuglar distant striation; colonr umber-brown with a greenish tint; spire rather short; suture impressed; whorls $6 \frac{1}{2}$; columellar maryin slightly curved, truncate at base.

Size: figured shell, maj. diam. 3.75 ; alt. axis $5 \cdot 0 \mathrm{~mm}$.

$$
\text { largest } \quad, \quad 40 \quad, 0.0,
$$

(ilessola crassula, Reeve, Bs. MS. (Plate CLIII. fig. 24.)

Locality. Darjiling To. 18.9.iii.1., B.M. Typical from Ir. likanford's collection.

thell elongately conical, smooth and shining, slender; sculpture: -ery few and distant stria ; colour nmber-brown; whorls $6 \frac{1}{2}$.

Nize : mat. diam. $3 \cdot 0$ : alt. axis. $7 \cdot 5 \mathrm{~mm}$.

$$
\text { largest ", } S \cdot(),
$$

These are all small and shorter than dimonsions giren in the original description, viz., $9 \mathrm{~mm}$.

In tho Jieddome collection are three specimens (No. 75:3) from the Naga Hills which bear a label in Col. Teddome's handwriting. G. crassula. I hase eompured them earefully and dramn the ajex (Plate CLAIV. fig. 18) mueh enlarged; it differs altogether in the sculpture from tyjical Darjiling examples of crassulu (Plate (LAIT. fig. 1.1) in the liknford collection (No.15) (Plate CLXIV. fig. 15$)$. No. 753 is G. baraliensis.

From the liarhichn in Mikhim J bave 7 examples (No. 2491). which 1 consider a rariety of the Darjiling form. The whorls have Hatter sides, and the apex is much more blunt (Plate CLIIT. tig. 15). The largest measures a little orer $y$ mm. in length.

In the 'Tauna of liritish India, Mollusca,' vol. ii. 1) 4.e?, under 
this species, "Khasi, Dafla and Naga Hills" is given as the range of this species and as collected by me. I bope sonn to sce these examples, not having found them in my own collection. The identification is Geoffrey Nevill's. I do not think he looked sufficiently closcly at them. Mr. Gude has simply copied from Nerill's 'Hand-list,' p. 169, "30 specimens." These I trust aro not now all mixed together. Jaintia Hills (Beddome) is also giren on 1. 429. These I hare seen, they are No.75l of my catalogue (5 examples). They are not crassula, but a small var. of cressilabris.

\section{Gerssula subjerdoni, Beddome, Nevill Mis.}

Under this title the species is recorded by Genfrey Nerill in his amended cojy' of the 'Hand-list' facing page 167. Four specimens from the Jeypur Hills, Madras, received from Col. R. H. Beddome. Nerill gires the measurement as: long. 9, diam. $3 \frac{3}{4} \mathrm{~mm}$; anfr. 7 . 'This would be the rar. minor of Beddome.

In the 'Fanna British India, Mollusea,' 1914 , p. 434, Mr. Gude gires Darjiling as a habitat of this species from specimens he had found in the Beddome collection. These are No.'814 of my catalogue of that collection: the name suljerdoni had been written by Beddome in pencil, a sign he had not determined it to his satisfaction; nor had I, when I came across it first in 1912, when under the divection of the British Musenm authorities I commenced working at the shells in the Bedlome collection aud making a catalogue of them. In August 1914. when duty in the country prevented my soing as usmal to fown, Mr. Gude obtained access to the Beddome collection of Glessula through those who had charge of it-very improperly, I consider, when it had been placed in my charge and a catalogue was in progress. Thus Mr. Gude was morking at this collection, quite nuknown to me, for a considerable time-some three months, - and when seen again by me was in a new state of arrangement, as put on record in my catalogue.

I $u$ the interents of the distribution of Indian species it would not be fair treistment to overlook such record. I have, therefore, gone carelully orer all the specimens of subjertoni in the Beddome collection, so as to arrire at some better knowledge of them. I have had photographs made of the shells aud mado myself enlarged drawings with camera lucida of the apical whorls of the following three specimens, a better means of showing differences than any description :-

No. 812. Bedl. coll. G. subjerdoni, Bedd., Golconda Hills. (Plate CLXIV. apex fig. 7.)

No. S09. Bedrl. coll. G. subjerdoni, Bedd., Teunerelly Valley. (Plate CLXIT. aper fig. 6.)

No. S11. Bedd.coll. G. subjeriloni, var. minor. Tyjical Jespur Hills. (Plate CLXIV. apex fig. 5.)

By this test the so-called G. subjerdoni of Darjiling (No. 814 of 
the lieddome collection) (l'late (LXIV. fig. 13) does not agree with the sucies from the typical locality, the (iolcond: Hills. It is, in uy opinion, a large viricty of Cilessula crassula, 13s.

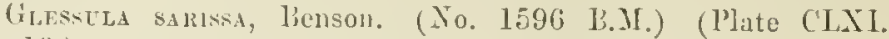
fig. 10.)

Faguirabanda, Jessore, Lower Bengal (Goduin-Austen)

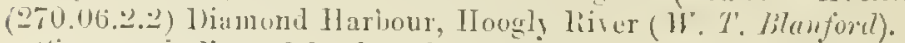

Size: maj. dian. 6.5; lengtl 15.5 nim.

This is a tiner specimen than the type described hy lienson hy marly $3 \mathrm{~mm}$. I givo enlarged figure ut the apex (l'ate CLXili. fig.. 1S).

Achatina sarissa, B. A. .I. N. II. ser. 3, rol. r. p. 4633 (is60).

()riginal deseription:- "Tistu domyuto-ronica, temui, laviyata, striatula, antractibus nltimis sublentr confertim obsentete denessatis,

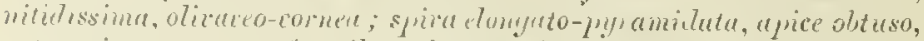
situra impressa; unfinctilnes $\frac{1}{2}$ conceriuscritis, ultimo $\frac{2}{7}$ testce super-

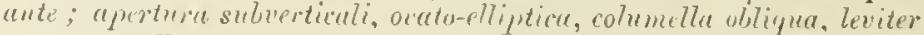
cremutu, albido-callosa, busi wblipue truncatu, peristomute recto, temi.

"Long. 16, diam. $5 \frac{1}{2}$ mill.; apert. 5 mill. longa, $2 \frac{1}{3}$ lita.

"Habitat prope Cumercolly, Bengulia, ad ripas flaminis Gangis-

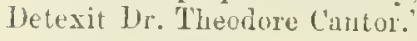

Glesscla gemas, Bs.; Reere, Conch. Icon. Achatina, pl. 22. f. 122.

Original description :- "Testa ou'uto-oblongu, solirliusculu, leri-

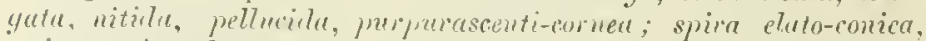

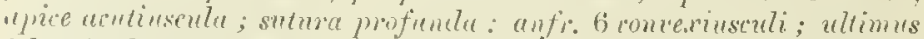

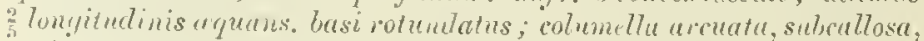

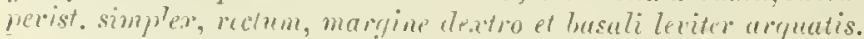

"Long. 8-8 $\frac{1}{2}$, dian. 4 mill., ap. :3 mill. longa 2 lata."

As a suhgenus of Cimplla it was uade the trpe lyy Ton Martens.

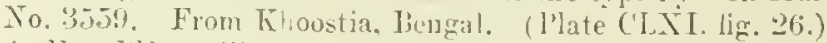

4. Hly. lilf. (3.iii.15). Frou Bengal; autlentic sp. (Plato CLII. tig. "-.)

No. 3342. From Chandanagore. (l'late CLXT. fig. 28.) liereive] from Terill.

万. Ily. Blf. (乌.iii.15). From Clittagoug, far. (Plate Clasl. tig. -29 .)

Jo. 3391 . From Garo Hills. I hare two speeimons. much smaller aud less tumid than the typieal shell. measuring $6 \times 3 \mathrm{~mm}$. Six whorls. This I distinguish as vir. minenta. It is darti umber in eclour.

This species is thus spread over the mlole front of the lyelta of the (ianges and liahnaputra. 


\title{
3. The Daflu II ills,
}

with the Plain of the Brahmaputra on seuth.

Glessulu (Tishetia) harmuttiensis, n. sp. sitrissa, Bs., val.

sarissa, Lis., val.

sulhebis, Nevill MS., n. sp.

nevilliana, n. sp.

dilirangense, n, sp.

(Dikranyia) nevilli, G.-A.

Glessula crussilubris, Bs. var".

see on, under this species-Khasi Hits.

\author{
Pl. CLXX. fig. 5. \\ Pl. CLII. fig. 8. \\ Pl. CIXIII. ligs. $16,17,19$. \\ Pl. CLXI. fio. 6. \\ l'l. CI.JIV. fig. 1. \\ ( Pl. CLXI. fig. Il. \\ Pl. CLXI, figs. 12, 13. \\ Pl. CLXIV fig. 3. \\ Pl. CLX. figs, $7,7 a$. \\ Pl. CLXIV. fig. 17.
}

Glesscli (lishetia) harudttifisis, n. sp. (Plate Clix. fig. 5.)

Locality.-ILarmutti, base of Dafla Hills, No. 14i B.M. (GodwinAlusten).

Shell elongately turreted; sculpture quite smooth to the naked eve, but under magnification distant obscure striation is seen; colour pale ochre to dull umber-brown; spire very long, sides flat, apex blunt; suture impressed; whorls 12, sides flat: aperture oral; peristome antor lip thin; columellar margin curving evenly.

Size: 1uaj. diam. $7 \cdot 9$; alt. axis $31.9 \mathrm{~mm}$.

This takes the place in the Dafla Hills of $G$. baculina of Sikhim. It is rery similar in all respects, but the apex is more obtuse and the sculpture is very different: there are four specimens.

Twa joung specimens, unnamed, were found in Henry Blanford's collection, giren to him by me.

Glessuli (Rishetia ?) sirissa, Bs. var. No. 445 B.M.

Loculity. Burrei Gorge, Dafla Hills, four specimens (GodwinAusten).

Shell elongately conical, smooth, and glossy; sculpture rariable, rather regular fine striation, in some it is less and more distant; colour very pale ochraccous; spires elongate, sides slightly convox, apex fner than in the type (Pl. CLIILI. fig. 16); suture impressed; whorls $9 \frac{1}{2}$, sides Hatly conrex; aperturo ovate; peristome thin; columellar margin sharply concare.

Size: maj. diam. $7 \cdot 0$; length $20.0 \mathrm{~mm}$.

$\left.\begin{array}{l}\text { Fakirabanda, Jessore } \\ \text { (typical spec.) }\end{array}\right\}$ maj. diam. 6.8; length $18.5 \mathrm{~mm}$.

Moisraka Gihat, Bengal, do. , , 75 ; , , 21.5 ,

The figure in the "Couchologia "Indica,' pl. xxxrii. fig. 2, is a rery good one, and undoubtedly of Bensen's species.

The Blanford collection (No. $\left.8 \frac{4}{4} 4,06.1 .1, B . M.\right)$ contained 3 specimens from the Dafla Hills, sent to him by me, but probably 
not the same locality. They are about the same size, and had been lihelled $G$. temispore? ly Blanford, hut thry are not like the 'leria Ghat examples with" which I lare eompared them.

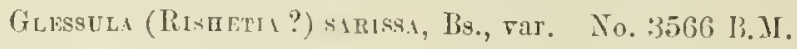

Loculity. Barowli Gorge, Durrang Distriet, Assam (GodurinAusten).

Sholl as in lisst: sculpture indistinct, fine longiturlinal rils follow bolow the sutise; colour pale dull ochraceons, two closely litrallel whitish bunds below the suture; suture impressed; whorls $\therefore$ regularly jnerensing: "olumellar margin concare.

Nize: maj. diam. $6 \cdot 0$ : length $16 \cdot 25 \mathrm{~mm}$.

Only a single specimen.

(ilessuli (Rishetia ?) sirissa. Bs., rar.

From Koliaghur, Granito Tila, near Texpur, on the left hank of the l3ralumaputra, a singlo speeinen very close to this species wats found by me; smooth, with little sculpture. No. 3568 B.M. ('late CLXI. fig. 8.)

Apex (PI. CLXIII. fig. I9).

From Gowhathi (No.33S3 B.M.), two specimens, the ipex is ret. more acuminate (vile Pl. CIXII1. fig. 17), but there is littl. difference to be noted in the gencral shape.

Glessclu suminges, Nevill MS., n. sp. (Plate CLXl. fig. (; ; Plate (LAIT. apex, tig. I.)

Locality. Pichola nulla, Datla Hills. No. 16is B.M. 'Type. Fire examples (Goctwin-Austen). No. $33+1$ B.M., Datla, typical.

Shell oblong turreted, thin, smooth, glassy ; seulpturr: rather distant and fine striation. slight tendency to crenulation at suture: culour very pale ochrnceous; spire long, sides slimhtly conrex, apex blunt, 3 first whorls nearly equal: suture impressed : whorls lu. with well-marked Hat couvexity; aperture narrowly orate: columella with a very slight eurve downward.

size: maj. diam. 50 : length $15 \cdot 75 \mathrm{~mm}$.

From the eggs in tube containing shells it is oriparous.

This species is entered by Nerill in the interleared copy (facing 1. I(iT) he lett to me shortly before his deatl, from the abure locality. He gives the dimensions of a specimen in the lndian Ilusenm which lie received from me: " $15 \frac{1}{2} \times 5 \mathrm{~mm}$., anfr. "1."

It is the Achatina ( $G$ lessula) heles in my paper on the IIclicido of the 1)afla Hills (Jour. Asiat. Soc. Bengal, vol. silv. 1t. "2, 1ST6, p. .315), and was a common shell.

Very formately I have receired from the Indian Museum, for whicli I hare to thank Dr. N. Annandale, the specimens of Cilpssulu included under Nu. 80 of Nerill's . Hand-list,' i. p. 170. 'Tlicy comprise ten glass-tubes, numbercd :- 
3031 and 3633, from Chittagong, both labelled "naja," a name I retain.

3632, from Cachar.

$3636,1)$ ikrang, ¿2000 ft., Dafla IIills: true subliebes, G.-A.

3i34, no locality : "macera" lilf., Issam; name retaiued and described. (Type.)

3338, Naga, Assan : is mastersi, G.-A.

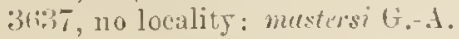

33:30), Assam. WT. Blf. "mucere" : is mestersi, (7.-A.

36:35, no loeality : naju, (i.-A.

$36+1$, Naga Hills : is mastersi, G.-- .

When Nerill wrote he considered them all the same and a new species; but it must be remembered that wlien Tevill was worling at this genus the same critical examination was not made of the shells, such as Pilshy adrised and adopted. The apex and sculpture was nerer looked at except with a lrand-lens; a microscope was nerer in use. 1 was employed for six months in 1570-15.7 in the Indian Museum, and saw Tevill constantly at work and oceasionally worlied with him.

'L"his has eaused much confusion, for he also appears to liare distributed them under the name of " naja." Inder this title he sent a specimen to Ir. Pilsbry, who deseribes ant figures it in "Manual of Conchology,' 2nd Sieries. Pulmonati, p. 90, pl. 12. f. 10, as "naja" from "Assanı." This turns ont to be the Chittagong species. I'ilstry's slell is undoubtedly from Assam; his descrijrtion as well as the figure is so good, it verifies the locality. He says, as to the seulpiture:- "Glimplses of excessirely weak close spiral granule-lines may be seen in jlaces." I hal not noted this mrself, but I now ste the character in my type-specimen of a Dafla Hill Glessula sulheles, an IIS. name of $\dot{\mathrm{i}}$. Nerill's wheh I harl alopted.

On the other hand, the rereipt of these shells in exactly the state Nevill left them (and he did a great deal of work on the genus, before lie had to retire from the Serrice, esprecially on species from Southern India sent to him ly (olonel Beddome) has aleared $n p$ the history and brought to linht another species. In Augnst 1880, Nerill, writing to me, said, No. $4(1)$ of his "Hand-list" was $G$. mrecera, and 1 took this to be his $11 \%$. namo for the lot montil he slould describe it. I hare not come across the name in the Blanford collection nor in Blanford's nriginal eatalogne. It is interesting to record that $\mathrm{Nos}$. 31334 and 3339 both bear this nalue on the labels in the glass tubes. and on tluat in 3634 Nevill bas written "A. macera, blf.," so we know the author. It turns ont that the two tubes contain different sjecies, and 3634 is a mixed lot of two species; for the rery elongate, fiat-sider form of one ot these the name masera is most alplicable, while it is not so for the more tumid shape of the other, which is mastersi. This fixes the habitat as Assam, aur ou looking through the Jlanford colleetion I find two unnamed Gilessula (No. St2.06.1.1 B.M.), the liabitat Assam, agreeing well in size anl form with "mecera." 


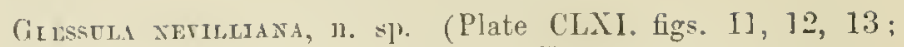
J'late (I.XIV. fig. 3, apex.) Xo. 449. 'Yype.

Lucality. Torputu Peak, Data Hills (t spocimens) (GodwinAusten).

Shell elongately conical; sculpture, coarse somewhat irregular striation; colour: two ruddy, two dull echriceous: spire high, apex blunt; suture impressed; whorls 9 , sides tlatly convex; a pert ure narrowly ovate; peristome thin ; colnmella rather straight, curred, short.

Sizc: Type ....... maj.diam. 5.0 length $17.0 \mathrm{~mm}$. whorls 9.

Nerill gives for specimens in Indian Inseum:maj. diam. 1.0 length $38.0 \mathrm{~mm}$. whorls $S$.

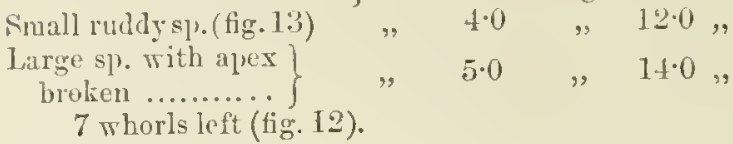

In this last, from last suture to baso of aperture $7 \mathrm{~mm}$., as against $5 . \frac{1}{2}$ in the Type.

This species is recorded by Nerill in his rerised copy of the - Hand-list, opposite prage 170, as "Stcnogyra (Glessula) arsteviena, Tevill-whorls 8, length 33, diam. $0 \mathrm{~mm}$., one Toruputu, Daflia Hills (Type), coll. Godriu-Austen." The specimen thus named is mrobably in the Indian Museum. I cannot find that it was erer jullished: therefore it is now named alter my old friend. His early death was a great loss, for he possessed a great knowledge of Indiau Mollusca, and liad made a close study of the genus Gilessula.

Glessola dikrazgexse, n. sp. No. 448 B.M. (Plate CLA. fig. T.)

Locality. Toruputu Peak, Dafla Hills-iu primeral forest. T! pe. (Golwin-Austen.)

Shell elougately turreted; sculpture very fue and close recular striation; colour oshraceons $\pi$ ith a strong green tinge; spire loug, sides very flatly convex, apex blunt: suture inplessed; whorls 9. envexity of sido rery slight; aperture oral, vertical; peristome strong; columellar margin curring.

Nize: maj. diam. $7 \cdot 75$; length $19 \cdot 0 \mathrm{~mm}$.

In a paper on "lhe Helicida of the Dafla Hills" (Jour. Asiat. Soc. Bengal, rol. xls. pt. ii. 1576, p. 315) 1 included Glessula illustris, the type of which was found on Hengdan 1'eak in the Tagat Hills. This was a hasty determination; alter a far more critical one, and a complarison of the photograjhs of both. it shows considerable difference, sufficient to constitnte a new species. The jroportion of the last whorl to the length of the axis is rery different to that of typical $G$. illustris-taking the axis as 100 , it is $100: 52$. 
Gresstla dikingense, n. sp. No. 3404 li.M. (Plite CL.X. fig. 7 a.)

Locrluty. Tormputu Peak, Ditla Hills (Gorlwin-Austen).

Shell oblongly turreted; sculpture rather strong striation, close and regular: colour dull umber-brown; spire higli, apex lilunt, side straight; suture impressed; whorls $s$, sile nearly Hat, spire to last whorl 100 : $52 \cdot 2$; aperture oral; eolumellar margin slightly convex.

Nize : maj. diam. $7 \cdot 0$; length $17 \cdot 25 \mathrm{~mm}$.

\section{"Dikpangia," gemus nof.}

Shell very elougate, small, truusparent, delicate, tmreted rith many whorls closely wound and nearly eymal in diameter, aperturo rerj small, orate; auinal not known.

\section{Glestura ("Dikraygia") yevilli, G.-A.}

When describing the Helicidre of the Mafla Hills (J. A. S. I. 1576, vol. x]r. pt. 2, pl, viii. f. 12, p. 315) I put this species into the genus Opeus. This determination has been followed by Il:. G. K. Gude in the 'Funna Iritish India, Mollusea,' rol. ii. 19] 4, p. 360. Closer attention shows the aperture to he decidedly that of a Glessula, but the general form departs mueh from that genus-so much so, it might well be placed in a distinct subsection. This would be better left to be done when the anatomy of the animal is known to $17 \mathrm{~s}$. I think it better to consider it a new subgenus. and name it "Dilwanju," comiug after Gr. buculina and $G$. yutopuse.

l'he original description, which is as follows, was short and requires amendment - it was not drawn up on one-type shells, but on a set-often done in those early days.

Orifimal deseription:- "Whell turreted, rery elongate, pale, silky with a yrren timge, older specimens of a pale straw-colour, corered with a thin equlurmis, becutifully strate unde 7 ens. Whorls 11-12, moderitely romded and very gradually diminishing in size to the apex, which is bluish; suture impressed; aperture angular above, outer lip tlin.

"Alt. $(1 \cdot 55) "$; major dian. $0 \cdot 10 "$. Largest specimens $0 \cdot 90 "$.

"Halitat. This rery delicate elongate shell was common on Toruputu Peak, but far finer specimens, equal in size to the figure, were obtained on the lanks of the Pichola Nulla ont in the plains. I am not satisfied with this figure, the whorls being rather too flat and the apex too sharp.

"I have nimed this sliell after my friend Mr. G. Norill, with whom I have $110 \mathrm{w}$ so long heen associated in the study and collection of Indian land-shells." 
Amended description.

Giessula xevilet, G.-A. No. 447 B.M.

Loiculity. Turuputu Peak, J)afla Hills (Goilwin-Austen).

Whell fnely elongate, turreted; sculpture, well-marked close irregular striation: colour white; spiro very slender and lengthened, apex blunt; suture impressed; whoris 12, the six list almost equal in diameter; aperture small, uarrowly and rertically orate; colninellar margin convex.

Size: maj. diam. 2.25; length $1+\mathrm{mm}$.

Var. majur, (i.-A., Pichola Xulla, Durrang District. This has a rery smooth surface with rery indistiuct striation, and has a green tinge. The largest specimen measures $17 \cdot 75 \mathrm{~mm}$. in length by $3 \cdot 5$, and has 12 whoris.

Although I refer to the Toruputu habitat of the Granite Peak on the main mountain mass 7322 f'et abore sea-lerel, and the Pichola Nulla low duwn and quite out in the plains, I now note, 40 years later, there is a difference something more than "far finer specimens," and that those from the Granite l'eak are very ditferent, particularly in size, proportion, and sculpture. Many conchologists would consider them distinct species-lowever, it is sufficient that G. nevilli stands for the momntain furm, the one first found by me, and that of the plains be considered a rariety mujor.

3 a. The Miri Hills.

From the great Talley of the Subansiri no species of Glessula hare becu receired; it is a large unworked area of 2.500 sq. nuiles.

4. Fastern Assam with the Singyho Hills and Pathoi Ranye.

Glessula mainensis, n. sp. 1'. CLX. figs. 10-11. dikingensis, n. sp.

Pl. CLAIV. fig. 4 (apex).

Glussula andarsis, n. sp. Fo. 1737. (Plate CLI. fig. 10.) Type.

Loculit!. Maiam Peak, Ningpho Hills; a single specimen (11. Ogle).

Shell oblongly turreted, rather tumin: sculpture: strong, rather distant, pugrared striation, showing strong near suture; colonr ocluaceons with a greenish tint; spire elongatels conoid, 
apex very blunt and rounded, sides flatly consex; suturo morlerately impressed ; whorls 7 , sides rery flatly convex; aperture oval; paristome unter tip thickened; columellar margin shghtly conrex, nealy straight.

Size: maj. dian. 15 ; length $2.2 \mathrm{~mm}$.

'The abure peak, a trigononetrieal station, is situated on the watcrshed of the Pitkai liange and is 6900 feet in allitule. It was first visited in the cold season of $1584-55$ by Colonel Woodthorpe, R.E., with his assistant Mrr. Ogle, and they were accompanied by Mr. Tom D. La Toueho of the Geolomical Surver, who published an excellent account of Geology of the Upjer Dihing Basin, Singpho Hills.

Glessula malanensis, n. sp. (Plate CLX. fig. 11.) No. 29 B.M. Lacalit!. Digung Talley, Singpho Hills; two specimens (M. T'. Ogle).

Shell is more elongate than the type: colour is greener: side of spire ruther Hatter; aperture ronuder, from the outer lip having more envexity. All the lind of lirersity the shells of this genus present, particularly when a large series is obtainable.

Size: maj. dian. 5.5 ; alt. axis $20.5 \mathrm{~mm}$.

\section{Glessula dihingensts, n. sp.}

Locality. Dihing Valles, Assam (type No. 3251 13.MI.); some ten specimens ( $I . T$. Oyle). No. 1600 B.M. from Sonari 'Tea Garden, near Saliya. (Plate CLXIY. fig. 4, apex.)

Shell elongate, turreted : seulpture: rery smooth generally, fine, close, rather strong ribling near and below the suture; colur umber-brown; spire loug and fine: snture implressed; whorls 11 , the last short; aperture orate, small; columellar margin well curred.

Size : maj. diam. $5 \cdot 0$; length $15.0 \mathrm{~mm}$.

This is not unlike $G$. macera, but the whorls arc not so close and the last is longer in roportion to those above, i.e., a more tumid basal one. Nyeeimens from Sadiya (No.3151 B.M., 10 in number, collected by my old assistant Mr. Ogle) differ in colour, being a rery pale ash, the largest of 9 whorls measures $21 \times 5.25 \mathrm{~mm}$. I hare also tro examples from Sonari Tea Garden, $15.5 \mathrm{~mm}$. in length, sent me by Mr. S. E. Peale, rery tinely and closcly striated.

4a. Abor Hills and Tsanspu Falley.

Gilessula oakesi, n. sp.

Pl. CLX. fig. 15.

aborensis, n. sp.

Pl. CLIII. fig. 4 . 
Glessula odkesi, G.-A.

Records of the Indian Museum, rol. viii. jt. xii. No.49, p.617, figs. $\mathrm{SA}, \mathrm{B}, \mathrm{C}, \mathrm{l}$.

Locality. Abor IIIl]s (Captain G. F. T. Oakies, IR.E.) No. 3600 B.11. Type. (Plate CLX. fig. 15x 1.56.)

Orifinal Descriplion:- "Shell oblong turreted, shining surface; sculpture : regular somewhat distant incised lines; colour ochraceous one umber brown; spire high, sides rery latly conrex : suture impressed; whorls 7 , flatly consex, proportion of bods whorl to length 100: 2.5; apreture rather narrowly oral, peristome onter lip thickened; columellar margin slightly conrex."

"size : maj. diam. $7 \cdot 0$; alt. axis $16.5 \mathrm{~mm}$."

"Two speeimens of this species, though rather smaller in size and not fully gromn, were sent to me from lirahmakund by Mr. II. Ogle, No. 3575 B.M. coll. The largest measures $11 \times 5 \mathrm{vm}$. The species was receired alive in 1913, from Captain Oalies with other speeies and disseeted." No doubt the tirst Gilessula so receired in this country; a few lired for some months until the winter set in, leeding on lettuce, ete.

"Animal of Glessula oakesi from liotung (Oakes). The sole of the foot is erossed by course ridge's, there is a rery distinct peripodial margian (text-tig. $3 \mathrm{~A}$ ). The gevitalia (figs. $3 \mathrm{l}, \mathrm{C}, \mathrm{D}$ ) was fairly well seen in one specimen, but more material was sadly wanted. The hermaphrodite duet is conspicuons from its size and close conrolution, hound closely together at its junction with the alhumen gland. 'The penis is rery short with a sbort stout flagelIum terminating in three blunt knots; it thus differs from whit 1 hare been able to see in other species. 'The ras deferens is giren off' from near the head of the penis, the spermatheca was not seen."

"This species ( $G$. oatesi) is the same as the one recolded from Rotung as G. botellus, Bs., of Sonthern India by Mr. H. B. Preston in the 'Reeords of the Indian Ilnseum,' rol. riii., Nov, 1915, p. 539 ; it is a bare record, in any case rewarkable as regards range. As I had not noticed this South lndian species among the large series sent me from the Ahor Hills, I was anxious to see the shells whieh had gone to Calcutta. Dr. Annandale rery kindly sent these to me (Oetober, 1910), and I have compured them with sprecimens of Gilessula botcllus in the Henry lilanford eollection from the Nilgiris, witl the result that I eannot conlinm Mr. Prestom's determination. This Ahor Glessula (oakesi) is decidedly smaller than $G$. botellus, and not so tumid, the whorls are closer wonnd, the outer lip is much more thickened than in butelles. the litrer shell. I hare compared the embryonic whorls and made enlarged drawings of botellus, Nilgiris (Pl. CXlIII. fig. 1). of Mr. Preston's specimen (I'l. CXl.11l. fig. 3), and of the type specimen of aulesi (Pl. CXLH11. fig. 2); the difference hetween the lirst and the two last is rery marlied, it is unistakable." 
An example ratlier more tumid was received from Capt. Oakes (No. 3155 B.H.), and one eame from near the Serpo liver bridge (No. 3053 B.M.).

Glessula aburexsis, G.-A. 3103 B.M. Type. (Plate CXlit. fig. 4.)

Rec. Indian Museum, 1918, vol. viii. pt. xii. No. 49, p. 618.

Localily. A bor Hills; fire specimens (Capt. G. F. T. Oates, R. L.).

Original description:- "Shell elongately turreted, sides nearly straight; sculpture: rery regular striation, less apparent on the last whorl; colour dark chestuut-brown in the type-shell, more ochraceous in others; spire attenuate, apex blnnt; suture inpressed; whorls 8, sides flatly convex; aperture orate; peristomo outer lip thin, with strong convexity; columellar margin nearly straight, feeble, slightly truncaterl.

"Size: maj. diam. 5.0 ; alt. axis $16.25 \mathrm{~mm}$.

"This species varies in form, some being less attenuate, but all have the blunt apex and similar sculpture."

5. Garo, Kasi, and Jaintia llilis.

Glessula tenuispira, Bs.

subaculina, n. sp.

=theobaldi, Hanley $\mathrm{MS}$

garoense, n. sp.

small vur.

manipurense, var.

subhastula, n. sp.

crassilabris, $\mathbf{B}$.

rar. nana.

pyramis, Bs.

hanleyi, u. sp.

solidus, n. sp.

Jadulamia abrormis, n. sp.
Pl. CLIX. fig. 3.

P1. CL11. figs, 4, 9.

Pl. CLIX, fig. I5.

II. CLIXY. fig. 11.

Pl. CLII. fig. 18.

Pl. CLX111. fig. 1\%.

Pl. CLX. figa 14, 1\%, 18, 19, 20 .

Pl. CLIIY. figs. 16,17 .

Pl. CLX, fig. 17.

Pl. CLXII. fig. 23.

Pl. CLX. fig. "’t.

P. CLXII. fig. 16 .

Pl. CLX11. fig. 8.

'1. CLI. figs, 22, 23.

Glessula tendispira, Benson.

Colonei Beddome, in his Monograph of the Genus (Pro. Malacol. Soc. rol. vii. $1906,1 \% 160$ ), records this species from many localities all very distant from each other, viz., Darjiling, legu, K. Cauara, Khasi, and Dafla Hills. In a paper by Benson in the 'Annals and Nagazine of Natura! History' (I $\$ 50)$, Le gires a list of all the Contineutal-Indian species of Achetina-in which A. tenuispire appears as from the Kihasia Hills, Darjiline, and Burma; he says also "In linrmah Mr. Theobald got a rariety of A. tenuispion on the banks of the Irawady." I have for long doubted that this species has such an extended range. Beddome even goes further 
and considers $G$. baculina, Hy. Blanford "only a more slender form of tenuispira" (Pl. Cl.1X. tigs. 1, 2) : he conld not pussibly liare seen the tyjes of the lormer species-the shell from the

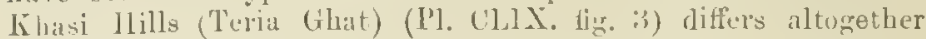
from the sililim one, and when they are placer side by side the points of difference are seen at once. I still more dunbt the extension of temuispira to North Canara as well as to Pegu.

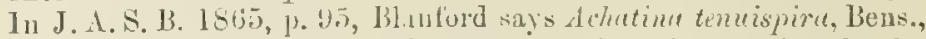
of small si\%e is common at Akoulstoung aud farther south. 1 refer to this under Glessula pertenuis, No. \&, Eust of Bay of liengal. 1 have not at present the shells to examine. Geofliey Nerill, 'IIand List,' i. 187s, p. I6!), reeords Darjiling, also Khasi and Iotha Iills; from these two last localities the slells were of wy collecting, for when Norill was studying the genus I smpplied him liberally witl specimens.

'The first recurd of $G$. temispira appears in a paper entitled "Deseriptice Catalogue of Terrestrial and Fluviatule Testacea, ehiefly from the North-Last Frontier of Bengul," by II. II. licusun, Jommal of Asiatie Society liengal, Jume 1S:ii, p. 350 .

(The Collection was purclased by the Asiatic Society in 1833.)

No. 11. in the List.-Achatina tenuispiza.

Original deseription:- "Testa elongata turrita, comea, longitudinaliter striatu, versus apicen attenuata, columnari, anfiractu ultimo interdum fucilis, quilusalum albidis transersis onuto, suturis impressis ipice obtuso.

"Long. 1 poll. circiter; lat. 0.55.

"This Aehatina, belonging to De Ferussac's subgenus Cuchlicopu and to his group of IIyloieles, is remarkable for thic attenuated columellar form of the terminal whorls of tho spire."

(Followed by No, 12, Crassitubris).

At the time this deseription was written, Beuson had not seen a llarjiling specimen; he was then Magistrate and Collector of Syllet, and there can be no doubt whatever typieal temispira came from that district-most probably from that rich collecting place Teria Ghat, which lies on its northern bonndary, where Jenson also obtained the very well-marked species $G$. crassilab-is.

Vie are alt to forget how inuch we owe to Renson and IIutton, the pioneel's in Indian Malaeology, who, with little assistance and encouragement, did so much. Looking back to the carly thirties and the many papers lienson liced to publish, it is noticeable low much his remarks inerease the interest in the species he discosered, how much is suggested as to relationslip and distribution. The hrothers Blauford fullowed with the same seientific treatment. In comparison the record of 10 -dily, with few exceptions, is bali to a legree, owing to a want of knomledge of the physical fuatures of the country, its size, and rarying climatic conditions. 
Grassula tenoispina, Bs. Coll. Hy. Blf., No. 11.9.ii. 15 B.Ml. (Plitte CLIX. fig. 3.)

Locality. Teria Ghat, Khasi.

Henry Blauford's collection contains + specimens from that plice, and I have 10 others (No. 1616 B.MI.) collected by myselt. The largest of these measures $31 \mathrm{~mm}$. long by $8 \frac{1}{3}$ breadth at the aperture. It differs in form rery considerably from what has been hitherto known as tenuispina of Darjiling and sikhim, which I have named aud separated as longispirce.

Glessula (Rishetia) tendispika, Bs. 11.9.iij.I5 B.M. (Plate CLIX. fig. 3.)

Locality. Teria Ghat, foot of Khasi Hills (ex coll. II. F. Blanford).

Shell elongately turreted; sculpture striation distant, closer, fincr, and regular towards the apex; colour ochraceous, with decided green tint; spire long, apex rather blunt, sides nearly straight, slight convexity; suture impressed; whorls $10 \cdot 5$, slightly convex, proportion of spire to last whorl 100: 29 ; aperture oval; columellar margin rather straight.

Size: major diam. $9 \cdot 0$; length $29 \cdot 0 \mathrm{~mm}$.

I obtained this species at Teria Ghat and also in the Test Khasi Hills, some do\%en specimens (No. 1592 B.AI.), the largest being $33 \mathrm{~mm}$. in length.

\section{Glessula (Rishetia) tendispina, Bs., rar. No. 3332 B.M.}

Locality. Garo Hills, a single specimen (Godunin-Austen).

Shell more slender in form; sculpture smoother than the Teria Ghat examples of temispira; colour ochraceous unber-brown; spire, apex fine; whorls I1, $100: 40 \cdot 4$; aperture narrewly orate.

Size: maj. diam. $8 \cdot 0$; length $27 \cdot 25 \mathrm{~mm}$.

Specimen from abore Tura, $10 \times 2 y \cdot 8$.

It is of considerable interest to note that Mr. S. W. Kemp, of the Indian Ifuseum, has recently collected Glessula tenuispiru at Tura in the Garo Hills, extending its range from Teria Ghat thus far to the west some 100 miles. Throughout this distance, the conditions are the same (tropical forest and for half the year excessire rainfall) on the steep spurs overlooking the great marshes of sylhet and Mymensing. Dissection shows the animal to have all the characters of the species I describe under longispira of Darjiling and Sikhim. It marks the western extension of the subgenus-this also falls in with the geological evidence we possess, that the Garo-Khasi area was in early Tertiary time much more intimately connected with the Sonth-Eastern Himalaya on the north and not so markedly cut off as now by the broad low valley of the Bralimaputra, filled with allurial deposits of great thickness. 
Glesstra (Rismetia) sobactirna, n. sp., Coll. G.-A. No. 3555 B.M. (Plate CLIX. fig. 9.)

Locality. Landomodo Trigonometrical Station. Type. N. Khasi Hills ( 7 apecimens); The Maothericluan Ridge (No. \$556) ( 4 specimens); South Jaintia (1 specimen). 'Tura, Garo Hills (ふ. W. Kemp).

shell elongately turreter; senlpture irregular, well-derelopel rather coarse striation, but varging much in different shells; colour ochraceous; spire elongate, sides fiatly conrex, apex blunt; suture rather slallow; whorls 12, sides not quite flat; aperture narrowly ovate: colnmella curring subotilynely, broadly truncate.

Size: maj. diam. $7 \cdot 25$; length $31 \cdot(1 \mathrm{~mm}$.

'This approaches the Sikhim $G$. luculine Iis., but is rather broader than that species, the whorls near apex jnereasing more rapidly. It is not so smooth aud shiny.

No.77 of Nerill's 'Hand list,' 1. 170, Gless. buculina-3 Khasi Ilils, presented by me, are sulaculina; they hare becu sent home (19I6) by Dr. N. Aumandale and compared by mo.

Glissula (Rishetia) stbacelina, G.-A., No. 1500 B.M. (Plate (LIX. fig. 4.)

Conch. Ind. pl. xrii. fig 5 as G. thenlaldi, Hanley MSS.

Locality. Teria Gluat, foot of Klıasi IIills (Godvin-Austen).

Sliell elungately turreted, slender; sculpure: striation of grow th strougest below the suture and most regular on the 5th and 6th whorls; colour umber-brown or dull ochraceous; spine elougate, apex fine; suture shallow; whorls 12, sides flat, proportion spire to last whorl I00: 2.4; a perture narrowly orate; peristome outer lip thin; columellar margin regularly conrex, not solid.

Size: maj. diam. $9 \cdot 5$ : alt. axis $34.75 \mathrm{~mm}$.

There are two specimens in my collection now in the Natural History Museum (No. I5so B.M.); their history is of interest and important with regard to the exact habitat of $G$. theulatli, Hanley.

Considerable confusion surrounds this speries, owing to the authors of the 'Conchologia Indica' working apart when it was passing through the press-one (Jr. Ifauley) in Fnglaud, the other ( $\mathrm{Ir}_{\mathrm{r}}$. Theobald) in India, dealingwith slsells from two very different localities. Hanley tirst describes the shell rery briefly of Achatina theobuldi, Conch. Ind. p. 9, IS70; in explanation of pi. xrii. fig. 5 , from " Near the Nalwen," he says, "Difters from $A$. cassicce, of $\pi$ hich it has been considerud a rariety, by its smoothnoss, more conrex whorls, \&e." The shell was therefore a Bucillum, and we can presume the species recorded by Theolald from the Shan States was also a Bacillum, vide a paper iu the Hournal of the Asiatic Society of Ihengal,' I870 (not 1571 as giren by (iude), vol. xxxix. p. 395ँ. On land-shells from the Shan States and I'egu as Actatina (Citesula) 
theobutrliun, Hanley, the footnote Conch. Indica, pl. xvii. fig. 5, shuws ns that that work was published and had been seen by him. In 'Nevill's Hand-list,' p. 172, we find "No. 102 Stenorygra (Glessula) theobuldi, Hanley, 2, Salween, coll. Mr. 'L'heobald." Nevill puts them in Bacillum. It is to be hojed these specinens are still in the Indian Museum, for they are very valuable; they would slear up where true Glessula thioluldi comes from. Hanley figured it on 11. xrii, but in the index 10 Adhetine in the Conch. Indsca, p. xii, to thcubuldi there is a footnote "2." "from Teria (ihat." It looks as if Ifanley bad substituted another species for figuring, and not taken the Shan one, under the impression they were one and the same. I am glad I am able to clear this up to a certain extent, and show bow a Khasi Hill form has got introduced. When Hanley mas engaged on the 'Conchologia Indiea' I sent him a number of species of Gilessula both named and umnamed, which he afterwards returned to me. Among them 1 have two specimens of a cilessulu nimed Theobulli-in Handley's handwriting-lrom Teria Ghat (No. 1580 , (rodwin-Austen Collection, British Mluseum). At the time I lent Ifanley my Glessule I had not a single species of the genus in $\mathrm{my}$ collection from the Salween Valkey, so there conld be no mingling of specimens. Turniug to pl. xvii., it may be noted at once that the shells are all enlarged; take, for example, G. orobiu (fig. 7 ) and G. prelustris (fig. 6). G. theobchli (fig. 5) has a rerr consilerahlo likeness to the Teria Ghat shell which IIanley returned to me with that name, allowing for similar enlargement with the seniptare also somewhat exaggeraled. At the samre time fig. 5 has not at all the form of a Breillum, measuring 42 mun, as given by Mr. Gude (ex jcon); ou the contrary, it has a fine attennate apex and not the characteristic blust. rounded oue of Bucillum (vide drawing by same artist, Mr. (i. B. Sowerby, of $B$. cossicue with its flat sides). All this points to fig. 5 representing the Teria Ghat speeimen, and it is quite possible the one photographed for me by Mr. T. S. Gladstune (PI. CLII. fig. 4) is the identical shell.

'Theobald's shells from the Salreen, in the Indian Ilnseum, cleared this ap ; for on making application tor them to Dr. N. Anmandale, the present Superiutendent, he has most obligingly sent them to mo (March 1916): the label is in type, a entting from p. 172. They belong, as Nerill records them, to the genus Bucillum; they are both imnature, the largest of 9 whorls, neasuring $2: 3 \cdot 25 \mathrm{~mm}$. in length, with sides of greater convexity than in $B$. cussiaca, distinguishing it at once. The typlical specimen sent home by Theobald to Hanley would appear to liave been lost: it is fortunate that about the same time Theobald gave specimens to the Indian Aluseum.

I found in the Bedlomo Collection (No. 121) a single, also immature shell, with a label "sent hy 'l'heohald as "Salwiniana." (In eomparison with the speeimens of $B$. theobuldi, Hanley, from Calentta, I consider it the same; it is on] $21 \mathrm{~mm}$. in length. Mr. Gude had marked it " young of cussicuce Bs." 
Glessora (Rishetia) garoesse, 11. sp. (Plate CLIX. fig. 15.)

Locrlity: South Garo IIills. 'Type. No. 1595 B.J. (GodwinAusten).

Shell attenuately turreted, sides flat, thin: sculpture, surface very smooth, a few distaut transverso shallow engraved liues, differing from the usual raised strice; colour pale umber-brown; spire fine; apex rery attenuate, first 4 whorls with same diameter (Pl. CLXIY. fir. 5); suture shall w ; whorls 13 , sides flatly conver, there is but little difference in the diameter at the (th whorl and the last; aperture narrowly orate: peristome thin, a callous on the body whorl; columellar marcrin oblique, very shight in structure.

Size: maj. diam. $5 \cdot 0$; total length $2-7.25 \mathrm{~mm}$.

In form it is similar to G. baculine, var. exilis of Silihim; the apex is not so attenuate, the whorls are flatter, and the sculpture differs considerably. In the sikhim form there is much raised striation.

Under No. 68, p. 169, of 'Nerill's Hand-list,' 2 specimens from the Garo Hills are recorded under $G$. pertenuis ; they mere presented unuamed by me. These have been lindly sent home for comparison by Dr. N. Annandale, to whom my best thanks are due : they are this species quroense. On this dita in the 'ILand-list,' Mlr. Gule in 'Fauna British India' extends the range of G. pertenuis, a Peru species, to the Assam liange; such record of distribution is ralueless.

Glessula (Rishetia) garoense, G.-A.

Locality. Sonth Jaintia; 4 specimens, No. 3562 (Godum-Austen). Shell attenuately turreted; senlpture, striation fery finc and close, disappearing in full-grown shells; colour dull umber-brow ; spiro tapering evenly; whorls 12.

Size: maj. diam. 5.5 ; length $26.75 \mathrm{~mm}$.

At first sight there is a remarkable similarity betwcen this epecies and $G$. pertemis, Wrm. Blantord, of Basscin. but it disappears under the microscope. 'The apical whorls are not alike, and the aperture differs still nore on the columellar margin and truncation.

Glissta (Rishetis) groosise, G.-A., small rar. (Plate CLIX. fig. 11.)

Locality. Naraindhur, Cachar; 11 specimens. Type. To. 165 t (F. Eile).

This measures $20.5 \mathrm{~mm}$. in length and $4.5 \mathrm{~mm}$. in maj. diam. It is of a darker umber than typical garoense, and has the very smooth surface of that shell; 12 whorls, sides slightly more convex; apex very fine, first \& whorls hardly increase at all ( I'l. CLXI I'. fig. 6).

I am fortunate in haring specimens in spirit of a small elongate many-whorled species fron silchar, Caclar, seut mo ly Mr. F. Lde. 
(The sole of the foot very closely segmented.) I have been successful in gettiug ont the genitulia, but in a detached state. The specinen containerl 8 well-formed eggs in the oviduct; they measure $1.5 \mathrm{~mm}$. in diameter, pertect globes. The penis (Plate CLXV. fig. (i) has an elongate simple sheath, with a rery small flagellum, close to the vas deferens attachment at the distal end. The spermatheea (fig. $6 a$ ) was elongate with a bulbous end ; the penis is thus similar to that of $G$. longispira of Sikhim, and it may ultimately be found that all the elongate turrefed Glessulc will have this type of male organ distinguishing them from that of $G$. ochrecea, \&c. The formula of the radula is:

$$
20 \cdot 7 \cdot 1 \cdot 7 \cdot 20 \text { or } 27 \cdot 1 \cdot 27 .
$$

The contre tooth has a long narrow plate with a small cusp at the base; the admedian are of the same shape as in G. longispira; the marginals are very numerous, becoming very minute on the outer edire. There are no intermediate tecth; the admedian merge into the marginais.

Glessula sebhastela, n. sp. (Plate CLXI. fig. 18; Plate CLXIII. fig. 15. apex.)

Locality. Nongsingriang, North Khasi Hills; No. 3551 B.M. Type (Gorluin-Austen).

Shell clongately conoid : sculpture irregular, fine clese, rery welldefined transferse striation (not so regnlar as in $G$. hastula); colour dark ochraceous: spire long attenuate (less so than hastula), apex fine (larger than in hastule); suture impressed; whorls $7 \frac{1}{2}$, sides flatly convex; aperture rery narrow, vertical; peristome thin; columellar murgin nearly striight.

Size: Type. Maj.diam. 3.25 ; lcugth $9.0 \mathrm{~mm}$. apex.

$$
\begin{aligned}
& \text { N. Khasi sp. (3546' B.M.) , } 3.5,10.75, \\
& \text { Teryest (3557 B.M.) ", } 3.50 \quad 12.0 \text {, }
\end{aligned}
$$

I first found this species (No. 3549 M.M., eularged apex, Pl. CI.XIII. fig. 14), which I then took to be hastula of Benson. in the deep valley to the east of Cherra Poonjoo the first summer I passe.] there. Two specimens were returned to me by Mr. Sy lvanus Hanley, in whose hands I placed a number of species of Cilessula when he was working on the 'Conchologia Indica'--this No. 35+6' (Pl. CLXI. fig. 1!4) was returued to me with a note in pencil "allied to sub/usiformis, IT. Blf?" A single suecimen of subhastula was also found in the Iunsiri Valley below samaguting.

I have receired a specimen from Mr. S. W. Kemp found at Tura, Gare Hills.

Glessela scbiastela, G.-A., var. type (Plate CLII. fig. 19.)

Locolity. North K̈hasi : No. $35 \pm 6$ (Godwin-Austen).

Shell elongatcly conoid; sculpture regular, quite strong striation ; colour rich umber-brown : spire long, sides flattened, apex blunt rounded; suture impressed; whorls $7 \frac{1}{2}$, sides flattened: aperture rather narrow; peristome slightly thickened; columellar margin nearly vertical, not truncated. 
Size: maj. diam. $3 \cdot 6$; alt. axis $10 \cdot 4 \mathrm{~mm}$.

This is much stouter and with a murh hlunter apex than typieal sublustula, with the aperture not so narrow; 9 specimens were found on Hinriutinolı l'eak. Yorth Caelar IIills.

No. 2026 B.M., apex enlarged (1'l. (LXI1]. fig. 12).

No. 355\%, North Kilusi, apex enlarged (Pl. CLXI1l. fig. 11).

Giessela illustris, G.-A. 3076 B.M. type.

Journ. Asiat. Soe. Jenga!, vol. xlir. 2., Is,5, p. 3. (Plate i. fig. 5.)

Figured in "Concholugia Inảica, 187.5, 11. eii. fig. \%.

Nerill, 'Hand-list,' i. 1s, R. 1. 1711, 7 sp., Hengdin.

Oxiginul description:- "shell elongately oral, greenish lornv, finely striated longitminally: whorls 7 , rery slimlity romuded: suture moderately impressed; the lip thickened; columellar wargin slightly eurved and strong: apex hlunt."

"length 0.75 ; maj. diam. $0 \cdot 3$ : lengtl of aperiure $0.3 \mathrm{in.}$

I/nt. Henglan Peak. Nonth (Gachn IIills. at $68+3$ feet, in forest, a]so near Nomolo, at couou fect, and in the Inlab Valley, Jaintia Ilills. at 1000 feet.

"This species is an clongate and larger form of chesulu ciassilubris, Bs., of which $G$. poyremis is a closer rariety; but its much more elongate form and stronmer striation make it is good comecting species with $G$. bitteri, described further on. The form from the Lukab Valley is a fumid departure from the trpe figured (var. temirle, (i-i.).

"One specimen-alt. 0.75: maj. diam, 0.3. in.

Another , , 0.65 , 0.35,

"I look on all these species as proper rarieties, and $G$. cressilahres, rery abmndant in all the grass country of the kiluasi Ilills, may be taken as the trpe; a lifference in eleration and cundition of halitat, from damp dark forest to lot grassy siopes, having produced modifications of form."

Amented description.

Glenstla illestris, G.-A. Type. No. 3076 B.AL. (l'late CIX. fig. 1:.).

Locality. Henglan Peak, North Cucliar IFills (Goduin-Austem).

Shell elongately oval, rather solid, smooth: sculpture: distant, fine irregular stria, fue on the apieal whorls; colonr deep olisaceots, with an ochre tint: spire high. sides thatly conrex, alpex blunt; suture moderately impressed : whorls 7, very flatly convex, ratler tumid; apertnre rather narowl oral, rertical: peristome thickened, lut not so strongly as in (Y.errssiluthis; columellar margin straightly enrred.

Nize: inaj. diam. $8 \cdot 0$; length $19 \cdot 2 \mathrm{~mm}$.

The last whorl up to the suture is ample: it measures from the hase of the columella in front to the suture 11.511 mu., proportion in terms of 100 is $100: 60$. The range on whieh it was found was corored for miles with magnificent forest. 
Glessula illustris, G. $\mathrm{G}$.

I have looked at the type after reading Pilsbry's remarks on this species (Man. Conch. scr. 2, xx. I909, p. 95, pl. ii. figs. 13-16). The rertical striation and grooring is irregular, but this is generally the case in the genus; on the apical whorls it is more regular. There is certainly fino spiral striation, bnt it is indistinct and not to be seen in some specimens; the suture is also not always crenulate. The striation on the embryonic whorls is very similar to that in crassiluhis. The examples from the Luka Valley in the Jaintia Hills (3075 B.M.) may be very mell considered a var. tumida.

Beddome erroneously considered it the same as $G$. facula of Southern India.

Glessula illostris, var. touida, G.-A. (Plate ClX. fig. 13.)

Locality. Lukah Valley, Jaintia Hills. No. 3075 B.Mr. (Goalwin-Austen).

Shell orate: sculpture: regular, incised striation, somewhat distant; colour strong ochraceous with slight olivaceous tint; spire moderatoly high, conic, sides flatly conrex; suture rather shallow; whorls $7 \frac{1}{2}$, the last tnmid, sides slightly convex: aperture widely oval, verticil; peristome slightly thickened; columellar margin rather short, subvertical.

Size: uaj. diam. 13.75; length $16.2 \mathrm{~mm} . ;$ length to body whorl $100:$ : $6:$.

Glessula crassilatris, Bs. 3435 B.Mr. (Plate Clu. fig. 17.)

Locality. Teria Ghat (Goduin-Austen).

Shell conically turreted, glassy; sculpture: distant, strong, transverse strice, rely irregular as regurds distribution and relief, near suture, very fine: colour bright ochraceous with a green tint; spire fine and pointed, sides flatly conrex; snture well impressed: whorls $7 \frac{1}{2}$, witl considerable convexity: aperture ovate; peristome onter nargin well thicleued; colnmellar margin concare.

Size : (Sp. figured) maj. diaw. $6 \cdot 0$; alt. axis $13.4 \mathrm{~mm}$.

The lurgest , , 7.2; , 14.75,

Note from Fietrl Bnok.- Animal with tentacles black throughout, body short, under side of foot pale yellow. The largest specimens were ohtained in North Khasi, wear Simleng on the Lubah River, in the high grass of old jooms. $i . e$. the clearings of rirgin forest, first cut down, then burnt and cultirated.

This species has locally an extended range, compared with other species, and it raries much in size, form, and colour. It is a rery cummon specics at Teria Gliat, the original locality, and I found it in the following places, specimens from which are fignred.

No. 355\%, From North Khasi.

One very larwe specimen firrued $16 \times 8.25 \mathrm{~mm}$. (Plate (TIX. tig. 14.) 
3435 B.II. Teria Ghat. Typical Jacality. (Plate CLXIV. fig. 16 , apex.)

Specimen figured $13 \times 6.65 \mathrm{~mm}$, apex rery fine, ochiraceous. (Plate CLX. fig. 17.)

452 B.II. Shengorh Poak, Dafla Hills.

crussilabris, rar.: the senlpture differs from that of typical shells in being much closer.

Specimen figured $13.50 \times 6.25 \mathrm{~mm}$. ; four obtained, all of a pale chrysophase green tint. (l'late CI.X. fig. 19.)

3553 B. II. Jaintia.

Largest specimen figured $14.5 \times 6.20 \mathrm{~mm}$, strong ochraceous, sculpturo dintant striation. (I'late CLIX. tig. 18.)

3390 13.11. Gnro Hills.

Fivecimen figured $9 \times 4.50 \mathrm{~mm}$., rery small. orately turector, dark umber-brown with a green tinge. (Plate CLX. fig. 20 .)

From other localities I Jaro:-

3:372 73. II. Garo Ifitls.

Lilrgest specimen $14 \cdot 20 \times 7 \cdot 0 \mathrm{~mm}$., dark ochliaceous.

3425 B.M. North Cachar.

Largest $13.25 \times 6.0 \mathrm{~mm}$., ochraceous with slight green tint.

:336s B.M. (towhathi, Assam.

10. $0 \times 5.0 \mathrm{~mm}$, ochraceons with slight greenish tint.

3569 B.M. Naga Hills, muder Laisom l'eak.

$15.0 \times 6.75 \mathrm{~mm}$, alex blunt, more elongate than type, greenish ochre; 7 whork.

45.2 13.M. Dafli Irilis, Shengor Peak. (1'late CLXIV. fig. 17, aper.)

Vers fine spiral strixe on the apical whorl (not shown in fig.).

453 P.M. Dalla Hills, in the Burroi Gerge.

$10.50 \times 4.80 \mathrm{~mm}$, dark umber, with green tinge deciderlly

olivaccons, more elongite, very distinct spirul strice on the apieal whorl.

91.3 T..M. Khasi.

$10.25 \times 50 \mathrm{~mm}$. 7 whorls, ochraceous, a jex rather blunt.

Blanford writes (J. A. S. B. IS65, p. 9.5): " I small variety of A. crassilabris, Bs, oceurs in Arakan, and another form perhaps distinet, but closely allied, was found in the Shan Hi]ls near Ara."

specimens of the first 1 found unnamed in Henry Blanford's collection collected by Mr. Laban of the Indian Ciril Serrice. I consider them distinct and have named them G. rahani. Those from the Shan Mills Jare come to light in Wm. Blanford's collection (No. 261-06.2.2), fire specimens. They are undoubtedly distinct, and I haro named the species $G$. feddeni after IJ Fedden of the Geological Surrey of India, who collected largely in that part of Burma. 
Glessola rrassilabiris, Bs., var. nana.. (Plate CldiI. fig. 23.) No. 1609 B.M.

Lovulity. North Khasi (2 specimeus) (Goduin-Austen).

Shell ohlong turreted, smooth and shiny; seulptnre: a few ineised lines; colour ochraceous with a green tingo: spire elongate, sides convex, apex blunt; suture impressed; whorls 7 , slightly consex; aperture narrowly orate; peristome onter lip thieliened slightly; ; colnmellar margin short, truncated, rather straight.

Size: maj. diam. $: 38$; leugth $8 \mathrm{~mm}$.

This shell, evidently fully grown, los much the form of $G$. crassilalris, and the sculpture is of similar character, but it is so very mueh smaller. There being only two speeimens it is better to ennsider them a dwarf Fariety than to gire a specific title. A single sperimen was also tennd in the Jatinga Valley, N. Cachar (No. 34l: B.3l.), another on Koliaghur Hill on the L.13. of the lirahmaputra (No. 35it B.Y.). white ret another from the Dunsiri Valley, alsu at a low eleration (No. 33922 B.M.).

Glegerla prrams, Bs. (Plate Clix, fig. 24; Plate Claits. fig. $2: 3$, apex.)

Locelity. Teria Ghat. 3550 G.-A. coll. (Godwin-dusten).

Achatina pyramis, Bs.

Original description :- "Testa ollongo-turrita, solisluda. levigata, striatula, mitide. luteo-corneo: spira turvita, lateribus conreciusculis, "pice obtusiusculo, sutura impressa ; anfractilus 8, converiusculis, ultimo $\frac{1}{3}$ tester aquante, antice absolete plicato; "perturu subverticali, elliptico-scmioruli, columella areuata, callosa, basi oblique truncuta, peristomate recto obtuso, intus allielo-lu'inato.

"Loug. 15, diam. 6 mill.; apert. 5 mill. longa, $2 \frac{1}{2}$ lata.

"Habitat al Teria Ghat Montium Khasi. Detexit W. Theobald.

"Allied to the smiller Ach. crassula, B., from Darjiling, but distinguished from it by its eolour, smoothor sculpture, more eonvex and numerons whorls, by the characters of tho peristume, and by the convex and not planate sides of the spire.

"A large variety of Ach. crassula, collect ed by Mr. IT. T. Blanford near Darjiling, is 1:2 mill. in length by $5 \frac{i}{2}$ in breadth, and, like the tylre. possesses only seven wborls."

E. pyramis is very smouth aud glassy. The largest specimen from Tiria Ghat figured measures $14.5 \times 5 \cdot 75$, slightly smaller than the specinen described by Bensou.

In the Beddome collection I found a single specimen (No. 7ti) named pyramis by Colonel Beddome: he does not refer to it in his note's on the gentus, al, hough its habitat is Ponsee. It measures $17 \times 6.8 \mathrm{~mm}$.

This is no doubt the Glessula pyramis, var. major, of Geoffrey Nerill, 6 sp., Ponsee coll. Dr. J. Anderson, vide 'Hand-list,' i. p. 169. In the copy which he gave to me, Nevill has written 
"var. mujor, Novill, $20 \times 8 \mathrm{~mm}$. anfr. 9." Besides its much liturer size, it diffurs in many respects from typical pyramis in tho general shape of the spire, the convexity of the whorls, and the fiom of the columellar margin, which is more enred and stronger thitu in lygremes, and I theretore name it G. ponsionsis. Since writing the alore I have recoved from the Indian Musenm tho specimens which Sevill dealt with, and have conpared them

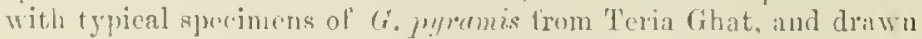
the apex of hoth. There is nom loubt the lonsi slaoll is quite distinct, ambl has no comsection with purmmis whaterer.

Description of tho liviog animal made in my Field look of one

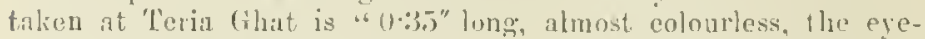
tontacles only darli coloured, a hack line extending from the base ol each along lhe upper side of the neck (this, of course, is the line of the retrictor muscle), foot short."

Glessula Hinleit, n. sp. No. 3547 B.M. (Plite CLXII. fig. 16.)

Locality. North Khasi. Type (Godurin-Austen).

Shell elongate; sculpture : few and histant extremely fine stria: colour pale ochraceous; spire high, sides with slight convexity, apex blunt; suture well inpressed: whorls 8 , side flatly courex; aperture narrow; peristome outer lip thickened; columellar margin vertical, strong, sinuate.

Nize: maj. diam. 475 : length $12 \mathrm{~mm}$.

This shell was seen by Mr. Sylranus Hauley, after whom I name $j$; he roturned it to me undetermined. It is a single slrell, but having a listory I am constrined to distinguish it, as I cannot lind anything like it. I at first placed it with G. buraliensis.

Glessula sol.ida, n. sp. No. 3548. B.M. (Plate CLIII. fig. S.)

Locatity. North Khasi Hills and raltey east of Cherra Toonjec (Gorluvin-dusten).

Shell olslong conoid, short, solid; sculpture: distant, irregular, fine striation ; colour vehracenns; spire elongately eonoirl, sides courex : suture well impresterl; wholls 6 , sides consex: aperture orate, rertical; peristome outer lip rery thickened; columellar margin short, conrex. well truncated.

Nize: maj. diann. $1 \cdot 0$ : length $5.0 \mathrm{~mm}$.

On finding this sholl I considered it to ho the same as Bensors $\mathrm{s}$ orolice, of Darjiling, hut it was not at the time ecompared with typical spreciuens. I find now it is very mucl smaller, rery ditferent. in its shape and proportions, the side of tho spire heing much more convex than in the llarjiling shells, with which $t$ have compared it, in the Ily. Blanford collection (No. 17.9.iii.15 B.M.). (1'late CI.IIl. tig. 6.) 
JАDTKAMA, subgen. nor.

Shell small, slort, solid, regnlarly ribbed, almost costnlate; spire elongately conoid: apex bluntly pramidal, rery rounded; columellar margin short, concare, and abrintly truncate.

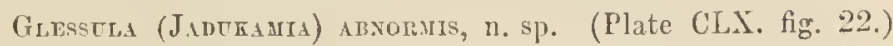
No. 1034, 06. 1-1.

Locality. Khasi IIills (Goduin-Austen).

Shell ovate: seulpture: close. regular, strong ribbing, almost costulate; colour ochraceous, shiny; spire clungately cumid, apex bluntly prramidal: suture well impressed; whorls 4 , sides flat, the first large; aperture ovate, not fully dereloped; columellar margin rertical.

Size: maj. diam. $4 \cdot 0$; alt. axis $7 \cdot 10 \mathrm{~mm}$.

This shell, torether with two specimens of $G$. crassitatris, was sent by me to $W \mathrm{~m}$. Blanford many rears ago, as pecorded in his eatalogue ; its peculiar form was not noticed. I then put it on one side under the impression it was an accidental rariety of some species. When going through the collection of Glessulce collected by mo in the 1)afla Hills, Assam. I came on another specimen among some found on the Sliengorh l'eak, almost identical with the Khasi Hill shell. When one considers the enormous areas-in Assam, for instanco--as yetunvisited by a conchologist, and compares them with the small scattered s]rots, miles apart, where often only a hurried search was possible, on one day in the year, there must be many a species yet to be discovererl. More extensive diligent seareh in both the Khasi and Datla Flills would lead, doubtless, to more specimens of this curious shell heing found.

\section{Giegsula (JaDUKania) abNomus, n. sp. (Plate Cl.X. fig. 23.)}

Loculity. Shengorh Peak, Dafla Hills. No. 3ito (Falwin-Lusten).

Shell elongately ovate: sculpture fine, very regular raised ribbing; colour pale ochraceus: whorls $t$, the first rers ample; aperture ovate; columellar marcin nearly vertical.

Size: maj. diam. $4 \cdot 0$; alt. axis $7 \cdot 20 \mathrm{~mm}$.

'This Glessulu is so distinet in shell character from all as ret known that $I$ am indueed to put it in a new subgenus, which I describo above. 
6. Torth Cachar, Taega Hills, am Manimer.

Glesubla burrailensis, G.-A.
burrailensis, var.
burruliensis, var.
burutlensis, var. maxwelli.
butleri, G.-A.
illustris, G.-A.
illustris, var. tumidla, G.-A.
stramencolor, n. sp.
munipurensis, n. sp.
imphalensis, n. sp.
oglei, n. sp.
Trouriensis, n. sp.
hehetata, n. sp.
burakensis, n. sp.
lahupaensis, n. sp.
liohinaensis, n. sp.
shirahiensis, n. sp.
lhotaensis, n. sp.
mastersi, n. sp. Type.
mastersi, var.
macera, G.-A.

Pl. CLX, figs. 1, 2.

1Pl. CLX. fig. 4.

Pl. CLX. fig. 3.

Pl. CLX. figs, 5, 6.

Pl. CLX. fig. 9.

PI. CLX. lig. I2.

Il. CLI. fig. 19.

Pl. CLIX. fig. 1?.

PI. CLIX. fig. 10.

Pl. CLA111. figs 13, 13 a.

Pl. CLAIl. fig. 24.

I'l. CLXII, fig. 10 .

I'l. CLXIl. fig. 13 .

PI. CLXII. fig. 206 .

Pl. CLXII. figs. 12, 17 .

I'l. CLAl. fig. '23.

Pl. CLX1. fig. 24.

I'l. CLXI. fig. 21, 22.

11. CLXI. fig. 25.

f Pl. CLYII. fig. I.

\{1'. ULAIIT. figs. 20, 2\%.

Pl. CLXII. fig. 3.

Glessula (Rishetfa) burrilexsis, G.-A. (Plate CLX. figs. 1, 2.) Type. No. 172.2 B.M.

J. А. S. Bengal, xliv. 1875, p. 3, pl. i. fig. 6.

Localaty. Khunho I'eak, Naga Hills, 'Trigonometrical Station (Goduin-Austen).

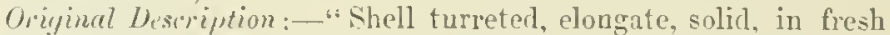
state brown and lustrous, hnoly longitudinally striated; whorls 10, rather Hat, suture shallow, apex lolunt; aperture subvertieal, fu<iform, angular above; peristome rery thick, paler brown on margin; columclla strong.

Alt. $1 \cdot 3$; major diam. 0.4 in.

The finest specimens were eollected under tho Peak of Khumho, Easteru Burrail Range; they were also abundant under Japro at about ; Oou tiet.

Size (Type, the largest): major diam, 9.5 ; length $33.5 \mathrm{~mm}$. $100: 44$, spire to last whorl.

This beatiful species is fonnd in the old damp and shady primuval forest.

Glessuia (Risuetia) berrallexsis, G.-A., rar. (Plate Cla. fig. 4.) No. 155.5 13.X.

Loculity. Kopamedza Peak, $8375 \mathrm{ft}$., Naga Hills, Trigonometrical Station (Gudwin-Austen). 
Sliell ruther more tumid in form; colour ochraceous, with a stronis green tint; whorls 8 ; eulumellar margin nearly straight, complared with type.

Size (splecimen tigured) : major diam. 9.25; length $26 \cdot 25 \mathrm{~mm}$.

Glessula (Risnetia) burrallexsis, G.-A., var. (Plate CLI. fig. 3.) No. 1556 B.II.

Locrlity. Japro Peak, Naga Hills, at 8-9000 feet (GolwinAuster).

Shell much more slender in form; apex blunt, shining : sculpture well marked, regular striation, extending to the apex; colour strong ochraceous, with a greenish tint; spire elongate, sides flatly conrex, sutnire impressed; whorls $9 \frac{1}{2}$; aperture ovate; peristome on outer inargin slightly thicliened; columellar margin slightly concare.

Size (specimen figured) : major diam. $7 \cdot 0$; length $25 \cdot 25 \mathrm{~mm}$.

llentiful in the forest, corering the Peak on all sides.

Glessula (Rishetia) butleki, G.-A. No. 1533 B.M. (Plate CLX. fig. 9.)

J. A. S. B. xlir. 3875 , p. 4, pl. i. fig. 7.

Locality. Eastern Burrail Rauge (Gulumin-Austen).

Original description:- "Shell elongately tureted, rers thin and brittle, tumid, pale corneous, glassy, very miuntely striated, apex rery blunt; whorls 8 , rather rounded, suture deep, hodywhorl mich swollen and capacions; aperturo vertical, pearshapred, lip rather thiu.

"Alt. 1·13, major diam. $0 \cdot 45$ in.

" Hab. Eastern Burrail Range, at 6000 fet ; not a common form.

"I name this shell after Captain J. Butler, Political Agent in the Naga Ilills, with whom I had the fortune of being associated when mapping that very interesting and beautiful district."

Size: Targest specimen, major diam. 12.75 ; alt. axis $28.0 \mathrm{~mm}$. Specimen tigured, ", $11 \cdot 0$; , 26.25,

Proportion of length to hody-whorl, $100: 54$.

Glessula (Risiftia) burratensis, var. maxwelli. (Plate CLy. figs. 5, 6.) No. 17I7 3.M.

Locrlity. Naga Hills, exact loeality unknown, but East of Tiohiua (Col. 11. St. P. Maxwell). Somra, Khulen Post. West of Kyendwin or Chindwin River, Upper Burma ( $F$. Ele $)$.

Shell elongately turreted; sculpturo coarse, elose, irregular ribbing (fig. (i); colour rich sienna-brown (lig. 6): spire long, sides nearly flat; $100: 47 \cdot 6$; suture shallow: whorls 10 , sides nearly tlat: aperture narrowly oval, outer lip strong: columellar margin nearly straight, solid. 
Size: Fig. 5. Type, major diam. $8 \cdot \overline{\bar{s}}$; alt. axis $: 32 \cdot 0 \mathrm{~mm}$. Largest hleiched sholl, $9 \cdot 6 ;$ $35 \cdot 0$

This species was given to we hy "Colonel Maxwell; obtained" on one of his tours in the Naga Hills, Eust of the Anghami Naga tribe.

Glesula (limmetia) arastirsi, n. sp. Tyje. (Plate CLAil. fig. 1.)

= macera, Nev. MS. from Assam.

Lorcality. Golaghat. Assam ; 3 specimens fouml. liff. Coll. Sti3.06.1.1 K.Ml.(N/astr's). Famelocality. 40.06.3. H.M., 2 examples; S37.06.1.1 B..ll., 5 examples.

shell elongately turreted; seulpture distant striation; colonr pale ochraceons; spine lons.r. sicles that; apex is fine, increasing gridually (1'1. CI.XIII. fig. 20); another specinell No. \$37.06.1.1 13 Il.. Blf. Coll., from same locality, l'l. (LX]Il. fig. 22), suturc shallow; whorls 9, very liaty conrex: proportion of spiro to last whorl I00:49, haring a slight shoukler below the snture; aperture ratler narrum; columellar margin noarly rertical.

Size: major diam. $6 \cdot 5$; leugth $17 \cdot 5 \mathrm{~mm}$. Largest specimen, apex broken, major diam. $7 \cdot 0$.

It is rery close to $G$. surissa, lis., but side of spire differs.

This species was found in 1)r. WT. T. Blanford's collection and unnamed. It was sent to him with otler shells found by Mr. Masters in 1860 , on the low spurs near the hot spring at the Falls of the Namba River, the home of that fine species lihiostona mastersi. fignred in the 'Conchologia Indica,' 1570 , pl. v. fig. 1, without description, as Peroragclos (spiraculum) mastersi, lilanford MSs., afterwards deserihed by Mm. Blanfort in Journ. Asiat. Sor. Bengal, 1S77, jt. 2,1 . 31:3, as from hills south of the Assam Valley not far from Golaghat. Sumo years later I happened to encamp at the exret locality as miseu above. The shell is hairy in fresh speeimens, as stated ly lilintord.

Among the Glessule siuce recorded from the Intian $1 /$ ssenm, muter No. So, Yevill, 'Hand-list,' p. 170, no. 3(3i39), are some 12 examples of masteisi from Assam. labelled Wr. 13lf. with the name "marere" in Nevill's handwriting. Writing to me in Alugust 18s0. Ferill gare this name to all the shells catalogued

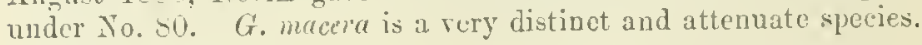

Glesscra (lismetia) mastersi, n. sp., var. (Plate CLXII. fig. 3.) No. 33.39 B.MI.

Locality. Augaoluo Peak, 6777 ft., Naga Hills, 2 specimens (11. Ogle).

Scmlpture: the embryonic whorls (Plate CLXII. fig. 21) are strongly eostulate next the smooth apex, and regularly so to the last whorl; colour dark nuber-brown; whorls 9 .

Fize : major diam. $7 \cdot 0$; alt axis $20.0 \mathrm{~mm}$.

Agrees with the (iolaghat specimens.

5 other specencus were obtained in the Yaga Hills; precise locality not noted. 
Glissola (Risigetia) macera, G.-A. W. Blf. MS. Type. No. 3673 H.M.

Locality. Assam, probably near Golaghat. Ex Coll. Indian Museum, No. $36: 34$ (IV. T. Blinford).

Shell elongrately turreted, thin: sculpture regnlar, close subdued costulation; eolour pale ochraceuus ; spire rers long, sides tlat; apex rather blunt; suture impressed; whorls 12, very gradually inereasing, Hatly eonvex, body-whorl short; aperture small; eolumellar margin flatly eursed.

Size: major diam. 5.75 ; length $20.0 \mathrm{~mm}$.

Under No. 65, Hand-list, p. 169 , Nerill records 10 specimens from Assam under $G$. pertenuis, presented by Stolickka-a fanlty determination; they are $G$. maceru, and from the same souree as No. 542.06 .1 .1 coll. Blf. B.J.

Gresstlat (Risnetia) strayexcolor, n. sp. (Plate CLIX. fig. 12.)

Locality. Burrail Rauge. 6 specimens. Type. To. 1535 B.M. (Godwin-Austen).

Shell elongately turreted, thin, shins; sculpture rather coarse, well-marked, resular transferse striation; colour very pale ochriceons, or straw-colonr; spire long, side that, apex very bluut; suture impressed; whorls 11 , sides flat; aperture small, pearshaped; peristome thin, outer lip rertical; columella curring downwards.

Size : major diam. $6 \cdot 0$ : length $25.0 \mathrm{~mm}$.

The general form and blunt apex of this species is more that of a Bacillum than of Glessula.

Glessula (Iísheti.s) imphaleasig, n. sp. (Plate CLIII. fig. 24.)

Localily. Munipur. No. 3398 B.Il. (Gorlwin-Austen).

Shell elongately turreted, with glassy surface; sculpture irregular striation; colour dull sirung ochraceous; spire elongate, apex fine, sides rery slightly eouvex; suture impresserl; whorls 8 , rather Hattened; aperture narrowly oral; onter lip slightly thickened; columellar margin short, truncate, very slightly concave.

Size : Largest, major diaw. 7.75 ; lewgth $15.0 \mathrm{~mm}$. Ordinary, , $\quad 7 \cdot 50 ;, \quad 10+1 \bar{\gamma}$,

Glesstid (Rishetia) yontpdrexse, n. sp. (Plate CLIX. fig. 10.)

Loculity. Mnuipur: orer 20 speeimens collected. Type. No. $155+$ B.M. (Godnin-Austen).

Shell elongately turreted, thin, shins; sculpture regular striation. showing strongly below the suturo as a erenulate edge; eolour pale umber-brown; spire long, sides with slight eonrexity ; apex fine, biunt (l'late (LNIV. fig. 8, apex), as comprared with G. guroense of Cachar (Plate ClXIV. fig. T, No. 1657 B.M.); suture impressod; whorls 11 , sides flatls courex; aperture small, 
suporate angular above and below; peristome thin; columella with rather a sharp turn, truncate below.

Nizc: major diam. 20.52 ; length $20.5 \mathrm{~mm}$.

'The sculpture distinguishes this species from $G$. garoense, small var, in being much coarser.

G. munipurense, n. sp., var. (3366 B.M.), Diyung Yalley, Naga Hills, differs very slightly from the type.

\section{Glessola subhastula, var.}

Locality. Munipur. 3 specimens. No. 3572 B.M. (GoduinAusten).

Shell elongately conoid; sculpture well marked, some irregular striso: eolour siemua-brown; spire high, sides somewhat that, apex rather blunt (l'late CLIIII. figs. 13. IB $a$ ); snture impressed ; whorls 8 , sides batly convex; aperture narrow, almost straight on the onter margin; peristome a little thickencd; columellar margin slightly courex.

Size: major diant. $3 \cdot 3$; alt. axis $10 \cdot 0 \mathrm{~mm}$.

Differs slightly from the Khasi IIill form in being less attenuate, the sides of the spire being more eonvex above the lareer bodywhorl, more particularly in the sharper apex, which is rery costulate throughout (Plate ('LXIII. figs. 13, $13 a$ ).

G. subhustula, n. sp. (No. 1591 B.M.), Lhota Naga Hills, four examples, similar to the type.

Gressula ogler, n. sp. Type. (Plate CLXII. fig. 10.)

Locality. Naga Hills. No. 220 B.M. (11. T. Oyle).

Shell elongate, oblong turreted; sculpturc regular striation; colonr bright ochraceous; spire high, sides tiatly convex; suture well impressed; whorls $7 \frac{1}{2}$, Hatly conves ; aperture orate; peristome well thickened on outer margin; columellar margin short aud shirlyly concare.

Nize: major diam. 5.5 ; length $14.0 \mathrm{~mm}$.

Somewhat like $G$. oakesi of the Abor Hills, but more slender and atteuuate, apex finer, and aperture more oral. More elongate than $G$. crossilabris, and the sculpture is not so incised as in that species aud its varieties.

Glesstla oglei, n. sp. (Plate CLXII. fig. 11.)

Locality. Naga IIills. No. 3363 B.M. (Gorlwin-Austen).

Sculpture rather coarse striation, not jucised; whorls 7 .

Size: major diam. 6.5 ; alt. axis $14.2 .5 \mathrm{~mm}$.

'The figure of this species is somewhat more tumid than the type, bnt found with it are two quite similar; they are not to be suparated. 
Glesstha hebetata, n. ap. (Plate CLyit. fig. 20.)

Locality. Munipur (Godwin-Austen). No. 3396 13.Mr.

Sliell ohlong conoid; sculpture irregnlar, rather close striation; colour dull ochraceous brown; spire elongately conic, sides flat.ly couvex, apex blunt; suture shiallow; whorls 6, rather Hattened; aperture narrowly oval: peristome onter lip slightly thickenor; columeliar margin short, slightly concave, terminating abruptly.

Size: maj. diam. $6 \cdot 0$; alt. axis $13 \mathrm{~mm}$.

No. 1539 B.II. hebetuta, n. sp., from the Ijurrail Range: larger than type, $16.5 \times 7 \cdot 5$.

No. 3340 B.M. hebetrtu, n. sp., from the Augaoluo Peak, Naga Hills; dark umber in colonr.

\section{Glessta barakexsis, n. sp. (Plate CLIII. fig. 12.)}

Locality. Munipur, south of the Barak Valley (Gocluin-Austen). Type. No. $3355=3349$.

Shell elongately conoir, smooth to eye: sculpture: fine, distant, regular, distinct stria; colour dull ochraceous ; spire high, sides flattened; suturo moderately isupressed; whorls 7 , sides very fiatly convex, $100: 5 S$; aperture very narrowly orate; peristome outer lip moderately thickened; columellar margin very slightly concave.

Size: maj. diam, $4 \cdot 75$; lengtl $12.0 \mathrm{~mm}$.

This is a common species in Munipur. I have it from Nongmaiching Peak (No. 3354 J3.M. Coll.), from the Lahupa Narga Hills on the north-east (No. S21 I.MI.), and from the Naga Hills, exact places unknown, but somewhere on the line of the Burrail Range. Thesc last (No. 3364 B.M.), are rather shorter, more tumid, and of an nuber-brown colour-10 $10.75 \mathrm{~mm}$.

In the Beridome Collection (British Museum STo. 753) wero originally four specimens (now three) from the Naga Hills, no doulst roceived from Mr. Mnspratt of the Assin Police-which Colonel Beddome had named crassulu, Tis. : thes agree with this sprecies. G. crassulu, Bs., does not extend to the Nagi Hills-sec what I say under that species.

Glefssula barikensis, n. sp. (Plate CLxII. fig. 17.)

Lncality. Burrail liange, Naga Hills (Godwin-Austen). No. $33+9$.

Shell ovately oblong, tumid; sculpture regular, sonew hat coarse striation, but not incised; colour dull ochraccuns: spire high, sides flatly convex, apex very blnut and rounded; suture very well implessed; whorls 6, decidedly convex; aperturo rather widely oval: peristome onter lip well thickoned; columellar margin convex just above the truncation.

Nize: Type, maj. diam. 4.75 ; length $11.0 \mathrm{~mm}$.

liather smaller than the type.

There is ono specimen from Tellizo Peak, Niga Hills (No. 3344 B.M.), near the watersliel of the Burrail liange. 
Glessrla rominatsis, n. sp. (Plate CITI. fig. 24.)

Loculity. Kohima, dughami Naga Hills, twelvo examples (Gorluin-Austen). Type. No.3395 B.M.

Shell orately oblong, slender', smooth, shing; sculpture: sparse, distant strie; colonr dull ochraceons with green tinge; spire high, enrving on columellar side parricularly; suture inpressed; whorls 7 , fairly cunvex; aperture rather narrow, vertically oral; peristome outer lip thickened; columella gradually curring, truncate below.

Size: maj. diam. 375 ; alt. axis $9.75 \mathrm{~mm}$.

\section{Gressuld Prowiensis, n. sp. (Plate CLYII. fig. 13.)}

Loculity. Prowie, Labupa, Taga Hills, X.F. Munipur, two speci-

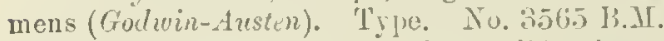

Shell elongately ovate, rather solid, gliss 5 ; senluture: very alight striation, distant; colour pale greenisli: spire high, sides flatly convex, apex rery blunt and romblel; suture impressed; whorls 6, siles slightly convex; aperture narrowly orate, rertical; peristome outer lip thickened; colunellar margin short, straight, nut truncate.

Size: maj. diam. 3.75 ; length $9.0 \mathrm{~mm}$.

I hare six other specimens from the Burrail Range (No. 1609 B.M.). From North Khasi Hills I collected two examples of a shell very like this ( $\lambda_{0} .355 \mathrm{I}$ ), more ovate iu form, with stronger truncate columella $5 \mathrm{~mm}$. Jong, and with au ochraceous tint-this is subhustula.

It is very variab in size. Specimens from the Lahupa Naga Hills (No. 3378 B.Il.) (Sikhami), six in number, are only $7 \mathrm{um}$. in length; of the same size are fire from Tellizo Peak (No. 3345 B.M.). Was also found on Laisen Peak in Munipur.

No. 768 12.4.16 B.M. of the Bedlone Collection is this species from the Naga Hills, fire specimens no doubt collected by Mr. Muspratt. 'These were labelled by Colonel Beddome G. orotia; jlaced in the box is a label in Mr. Gude's handwriting " 1 subjercloni," the four other specimens are prowiensis. See what I say under $G$. orobia.

No. 3336 B.M. mowiensis was collected south of the Barrail, Munipur.

To. 3362 B.M. prowiensis was collected on Khunho Peak, Naga Hills.

No. 3334 B.M. prowiensis $\pi$ as collected at Kezameh, Naga Hills.

Glessula smirobiensis, n. sp. (Plate ClLI. fig. 22.)

Locality. Shiroifurar Trigonometrieal Station, Lahupa Naga Hills (Godwin-Austen). Type. To.357I 13.AI.

Shell elongately conoid, rather solid: sculpture regular, fairly strong striation; colunr ash-bruwn, paler un apex; spire elongate, 
sides nearly flat, apex rery blunt: suture impressed; whorls $6 \frac{1}{2}$, flatly confex; uperture narrowly oral, vertical, milky-white inside; peristome thickened; columellar margin nearly rertical.

Size : Types.......... maj. diam. 3.0 : length $8.0 \mathrm{~mm}$. of larger bleached specimen, " $3 \cdot 25 ; \quad, \quad 9.0$,

Glessula liotanse, 1. sp. (Plate CLXI. fig. 2.5.)

Locality. Lhota Naga. Small, elongate (Godwin-Austen). No. 1590 B.M.

Shell elongately turreted; sculpture: distant irregular striation, with broad smooth interrals: colour pale ochraccous; spire higl, apex blunt; suture well impressed; whorls $7 \frac{1}{3}$, siles thattened, jnoportion of length to body-whorl 100: 49 ; aperture narrouly elliptical ; poristome thin ; columellar margin perpendicular, ncarly straight.

Size : maj. diam. $3 \cdot 8$; alt. axis $10.25 \mathrm{~mm}$.

Glessula taitupaense, n. sp. (Plate Clixt. fig. 23.)

Locality. Phunggam, Lahupa Naga Hills (Golwin-Austen). Type. No. 3381 B.M.

Shell elongately turreted; sculpture regular, rather distant striæ; colour pale umber-brown; spire high, subulate, apex rounded, large, blunt; suture impressed; whorls 6 , sides somewhat flattented, proportion 100:46; aperture oval, well rounded below, rertioal; peristome outer lip thickened; columellar margiu nearly perpendieular, with rery slight eurrature.

Size: maj. diam. $3 \cdot 25$; alt. axis $9.25 \mathrm{~mm}$.

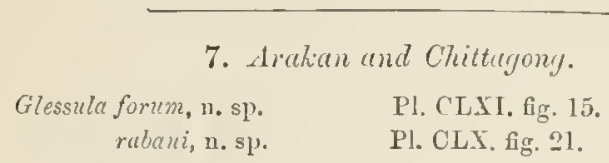

Qlessola fordi * n. sp., is naja, G.-A., Blf. MS., not naja of l'ilsury from Assam, which is sublubes, G.-A. (Plate CLII. tig. 15.)

Locality. Hathagori, north of Chittagong. Ex Hy. BIf. Coll., six specimens (H. C. B. C. Raban). No. 1t.9.3.15.

Shell elongate; senlpture: surface smooth, rather weak distant striation; colour ruddy ochraceous; spire long, sides slightly convex, tapering gradually to apex, then sharply at the 3 apieal whorls; suture shallow; whorls 10 , very slightly convex, proportion of spire to last whorl $56 \% 2: 100$; aperture widely oral; columellar margin, with slight conrexity.

Size : maj. diam. 795 ; length $22.25 \mathrm{~mm}$.

*From the name of the place it ca!ne frum, which means the "warket rillagre." 
Approaehes $G$.tenuispira, Bs., which has been recorded from Sylhet (probably the typieal locality), from Pegu, Akouktoung, and farther south. This is a species which would hare been likely hy some of the early collectors to be considered temuspira, but it does not agree either with Teria Ghat examples I have, nor with Gless. mastersi from Assam.

Glessula rabani, n. sp. (l'late CLX. fig. 21.)

Locality. Chittagong. Ex Coll. Henry F. Blanford (H. Raban). No. 6.9.3.15.

Shell ovately conical, turreted ; sculpture: coarse distant striation partly incised; colour rich sienna-brown; spire conic, sides slightly convex, apex blunt; suturo impressed; whorls 7 , sides tlatly convex: aperture narrowly oral; peristome thickened on outer lip ; columellar margin short, conrex, thickened, truncate.

Size: maj. diam. 5.0 : length $10.25 \mathrm{~mm}$.

This is very close to $G$. crassilabris, but the spire is not so high, the aperture is narrower, and the coloration different from any speeinens I have scen from the Khasi Hill liauges. I name it after Mr. H. C. B. C. Raban, of the Indian Ciril Serrico, who collected assidnously in the districts in which he serred.

\section{Burmese.}

Glessula pertenus, W. Blf. basseinensis, n. sp.

I'I. CLXI. figs, 1, 2.

nathiana, n. sp. akouktoungensis, n. sp. Ulanfordiana, Xevill. peguensis, W. Blf. ponsiensis, n. sp. f Pl. CLXI. fig. 3 \{ Pl, CLIIT. fig. 10 .

Pl. CLXIV. fig. 21.

Pl. CLXII. figs. 20, 21.

Pl. CLXIV. figs. 19,20 .

8а. Texz̧asserim.

Glessula limborgi, n. sp.

Pl. CLXI. fig. 5.

Glessula pentendis, W. Blf. (Plate CLXIV. fig. II, apes; Plate ClXI. figs. 1, 2.)

Lacality. Tongoop, Arakan; and Henzada. No. 239.06.2.2. (IV. T. Bilunford).

Original description:- "A. pertenuis, n. sp. Shell rery slender, turreted, thin, light homy, polished, closely, minutely, and rather irregularly striated. Spire subulate, somewhat acuminatc towards the blunt apcx; suture impressed, suberenulate. Whorls 11-1:2, consex, the last abont $1 / 5$ the length of the spire. Aperture oblique, orately pyriform. peristome thin margins united by a thin callus, columella woderately curred, obliquely truncated. 


$$
\begin{array}{lll}
\text { Length } \ldots \ldots \ldots \ldots \ldots \ldots \ldots \ldots & \begin{array}{c}
\text { millim. } \\
20
\end{array} & \begin{array}{c}
\text { ineh. } \\
0.3
\end{array} \\
\text { Diameter } \ldots \ldots \ldots \ldots \ldots \ldots \ldots & 4 \frac{1}{3} & 0 \cdot 18 . \\
\text { Length of a perture } \ldots \ldots \ldots \ldots \ldots & 4 & 0.16 .
\end{array}
$$

"Habitat. Tongoop, Arakan.

"Var. mujor, length $26 \frac{1}{2} \mathrm{~mm}$.; diameter 6 ; length of aperture 6 . Of another specimen; length $23 \mathrm{~mm}$; diametor $5 \frac{2}{3}$; length of aperturo $5 \frac{1}{4}$.

"Habitut. Pyema Khyoung, Bassein District, Pegu.

"A much more slender species than A. tenuispira, Bens. (a variety of which also abounds in parts of l'egu), though there are signs of a passage. The present appears to replace A. temuispira in Arakan and Bassein. Mr. Benson, to whom I sent a specimen, observes that it is intermediate between $A$. tenuispira and A. hastula, Bens."

No. 239.06.2.2 of the Blanford collection is represented by seren examples of this species, with this pencil note by Blanford, "very like tenuispira," trom two localities, Tongoop, in Arakan, and Henzada on the Irrawady, the respective locality was not indicated; but they are all alike, two are of the same length as giren in the description-riz., $20 \mathrm{~mm}$., white. The largest specimen now figured is $22 \cdot 25 \times 5 \mathrm{~mm}$.

Fortunately I bave from Henry Blanford's Collection ( $\mathrm{N} n$. 20.9 .3 .15 ) two specimens from Henzada, one of which $I$ figure; it is $22.0 \mathrm{~mm}$. long $\times 5$ in major diameter, which settles the matter of habitat. They no douht were given him by bis brother.

Uuder G.pertemis, var. major, William Blanford gives the dimensions of a larger form from the Bassein 1)istrict, which is farther to the south. Three examples from this locality are in the Henry Blanford collection; they do not agree with pertemus, the general shape is different, the auex particularly being much blunter. It cannot be therefore considered a variety-I name and figure it as G. basseinensis (Plate CLXIV. fig. 10 for apex).

In Col. Beddome's Collection (No.6S2) is a single large specimen, 26.75 in length $\times 7 \mathrm{~mm}$., from Thyetmyo, named by him $G$. baculina; it agrees best with $G$. nathiona; it has much the general form of pertenuis, but is larger, is ash-colonred, witl rough strong striation. A hasty eximination recalls so-callerl tenuispira of Darjiling, but a closer shows quite a different increase of the whorls, and that they are by no means so flat. It is also milky white within the aperture, quite a distiuguishing character, which I note is to be seen also in the typical specimen of $G$. pertenuis from Henzada. Nevill records pertenuis from Akouktonng and Thyetmyo. This large form must he the rariety of tenuispira referred to by $\mathrm{Wm}$. Blanford as abounding in parts of Pemu, and in his "Contributions to Indian Malacology," 1S65, J. A. S. B. Fol. xxxir. p. 95, he says: "Aehutina tenuispira, B., of small size, is common at Akouktoung and farther sonth."

On the same glass slip in the Blanford Collection ( To. $_{0}$ 239.06.2.2) wero gummed five specimens, labelled $G$. tenuispira, 
P'sgn and Darjiling; four were certuinly from the latter place, but one was yuite a different species and smaller, and may liave come firm l'egu.

Norill gires the (iaro llills on two speeimens from my collection; this cannot be an accurate determination, as I hare nothing like it. The ten speeimous from dsiam aro something else.

Recently (July ] groing through $1 \mathrm{rm}$. Blantord's collection of duplicato shells, I came on funr jill-boses containing Gilessulu froun l'egu, with truc locality and named as follows:-

To. 1 contained Achatina temuisprim from Bassein District. 14 examples; No. 2 from Alioultonng, $1 \mathrm{~s}$ examples; No. 3 Achatiure pertenuis from 'Tongoo], whieh is on the Arakan Yoma, 3 examples ; No. 4 "intermediato hetween temispirer and pertenuis" from l's wal Kihyoung, Bassein District, 20 examples. T'hese clear 11 p dunbts an distribution and slow so well what blanford's views were at the time he was describing Pegu (ilessulas. Yo. $t$ is G. bresseinensis, described further on. No. 2 dilfer's from this in many respects, due, no donbt, to its habitat on the limestone rocks, which the name implies, "Akouk" being line and "toung" a hill in liurnese; I remember the place well. I aropt it as the specitic 1rame. No 1 is a well-defined spories differing lrom the preceding, which I name $G$. muthiunt. from the Burmese name "natll "for spirits or fairies of woods and hills.

Giresstat misseinessis, n. sp). (Plate CIXIT. fig. 12, apes; Plate CLXI. fig. :3.)

Loratity. Balssein, J'egru, three specimens. J'yoma Kihyoung, Bassein, six speciuens (I). T. Blution(l). Type. No. 199.3.1.) 1).MI.

Shell elongately turreted: seulpture elose, fine, regular, rather coarse; colour achracous; spire elongate, sides worly straight. very slightly actuminate near the hlunt apex, $100: 33: 5 ;$; mure molerately impuesed; whorts 11 , riden very thatly convex; aperture narrowly orate; colnmellar margin enred slightly.

Size: major fliam. $(; \cdot 25$; alt axis $250 \mathrm{~mm}$.

This is the rar. mujor of pertemuis lilanford allnded to ahove; it is not so attennate in general form, the apex is mudl stronger and blunter, ferwer whorls, white, longer, and the sculpturo coarser: a comparison of fogure (No.3) with thuse of true temispire from 'Jeria Ghat and hustulce shows, better than any description, low much it differs.

Glessula (Risuetris) xathina, 11. sp.

Locality. Bassein District (IV. T. Blanfoml). TYpe. So. 2206 ก6.1.1 13.3I.

Shell elongately turreted: sculpture regular, finc, raised, elose etriae throughout; colour strong, ochraccous; spire clongate, sicles 
nearly flat, apex very bluut; suture well impressed; whorls 11 , sides Hatly convex; aperture broadly orate; columellar margiu very consex.

Size: maj. diam. $7 \cdot 0$; length $22.75 \mathrm{~mm}$.

This species was fond among Blanford's duplicate shells, the box marked with above locality and with the note "intermediate between temispire and pertenu is"; it differs quite sufficiently from both and from busseinensis to bo distinguished. From the last, it is far longer at the body-whorl, which is rery swollon, its sides more convex, and the apex is much larger.

\section{Glessela AKOUKTеUNG ENsis, n. sp.}

Locality. Akouktoung on Irawady, Pegu (W. T. Blanford). Type. No. 2207.116 .1 .1 B.M.

Shell elongately tarreted; sculpture scarcely any, just a trace near apex below the suture: colour umber-brown; spire long, sides flat, apex blnnt; suture impressed; whorls 10 , sides flatly conrex; aperture orate.

Size: maj. diam. $5 \cdot 75$; length $20.5 \mathrm{~mm}$.

This species occurred among the duplicates in the Blanford Collectiou. Compared with $G$. bussinensis, it ditfers in sculpture, in colour, and the last whorl is more tumid in proportion to the length.

Glissuld pegubasis, M. Blf. (Plate CIxII. figs. 20, 21.)

Locatity. Pegu. No. 8.9.3.15 (H!. Blunfurd).

Origina' lescription:-"A. preyucusis, n. sp. Shell oblongorate, rather soid, dark reddish brown, horny, marked with distinct and regular impressed lines. Spire envexly coniral : apex obtuse; suture impressed, suberenulate. Whorls i $i \frac{2}{2}$, slimbtly convex; the last ascendiner a little towards the munth. ind exreeding $\frac{1}{3}$ of the sbell in lengtlı; aperture rertical, trunealely semicircular; peristome obtuse, slightly tbickened: margins juincl by a callus; columella rery much cuxed, projecting forwards at the base, subvertically truncated within the peristome.

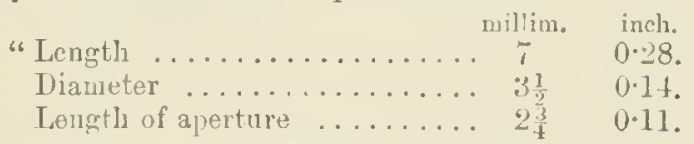

"Hntitut. Irawady Taller, Pegu: common.

"A pretty little sjecies, darker in colour than any of its allies, except purhaps A. pemina, Bens., and easily distiugnished from all, by the columella being more arcuate, also by its more acuminate spire and blunter aper, and its much stronger sculpture."

I gire two fioures of this shell, from authentic specimeus in Hy. Blanford's Collection, as there is some rariation in form. 
Iu the Blanford Collection (No. 262.06.2.2) are threo specimens from Arakan, near Tongoop, much lurgor than the type deseribed, being $10 \times 4.5 \mathrm{~mm}$, but they do mot differ in any other respect, and may be eonsidered a larie variety.

Gressula ponsiesis, n, sp. (l'late CLII . fig. 19, apex.)

Loculity. Ponsee, Iumnan. Coll. Indian Museum (Dr. John Anclerson).

Shell oblong turreted, solid, smootls to ere; apex rery rounded with flattened sides; sculpturo: nono discernible cn the two apical whorls, slight striae on 3rd regularly, distantly, and tinely costulute on the th; colour pale ochracens; spire tapering, apex blunt, sides rery slightly convex; suture shallow; whorls 9 , sides flatly convex; aperture ovate, rertical; peristome somewhat thiclicned; columellar marrin strong, concare.

Size: maj. diam. 7.75 ; alt, axis $20.0 \mathrm{~mm}$.

'This is Stenogy'a (Glessula) myramis, Bs., rar. major, of Nerill, 'Hand-list,' i. p. 169 , relerred to under $G$. pyramis by me. 1 am fortunate in getting the type-shells for examination. 1 always duabted the extcnsion of $G_{0} /{ }^{\prime \prime} /$ ramis so far to the eastward, when it had never occurred in the Naga Hills or Munipur, or eren Eastern Assam.

Glessula blanfordiana, Nevill: Ponsee (Dr. J. Anderson). I am able to state that this is No. $\$ 5$ of Nerill's 'Hand-list,' p. 171, as entered in Geoffrey Nevill's amended copy in his own handwriting ; that he did not at that time consider it had any elose relationship to $G$. peguensis, is shown by the two lines crossed out, aud "6, Loc? coll. W. Theobald," Hhamao, is entered as the habitat.

The type from Ponsee, Fumnan (Plate CLIIV. fig. 20, ajex), has been sent mo from Calcutta by the Director of the Zoological Surrey of India, Dr. N. Annandale, with one other example. This typo is, I should say, abnormally thickened, particularly on the columella and tip of the peristome. Nerill's description is excellent.

1 closely compared these with the specimens also collected by Dr. John Anderson at Bhamao ('late CLXIV. fig. 21, apex), six in number, and made drawings of their respectire species, which show considerable variation not unounting to specific difference.

The sculpture of the Ponsee shell is distinctly cestulate, while it is rery finely so in those fron Bhamao (Plate CLX15. fig. 21 , apex), and this extends to the whole apex, as in the trpe (fig. 20 ).

As Glessula peyuensis has been referred to as an allied species, I compared and figured the apex, which is of rery different form and sculpture (Plate CLXII. fig. 22, apex)-the specimen selected being one in the $\mathrm{Wm}$. Blanford Collection trom 'Tongoop, Arakan.

Glessula limborgr, n. sp. (Mlate CLII. fig. 5.)

Localit!. Tenasserim (Ossirm Limhory).

Shell elongately turreted, with shining surface : sculpture : very 
rogular striation, less apparent on the last whorl; colour rich umber with a green tinge; spiro elongate, sides nearly that; apex somewhat attenuated, blunt; suture shallow; whorls 1], increasing very gradually in size, sides tlattened, the last with a sign of a kecl above the aperture; aperture rather narrow, ovate, straight on inner margiu: outer lip tlatly concex; columellar margiu sharply convex, then straight not solid, feeble truncatiou.

Fize: maj. diam. $6 \cdot 5$; alt. axis $26 \mathrm{~mm}$.

This single specimen was among the shells collected by Mr. O. Limborg in $18 \% 7$, and I name it after him; it has remained undescribed ever since. The species is of delicate form, and quite distinct from any Glessula 1 have from Pegu.

Mr. Ossian Limborg was a particularly fine strong young man, son of a Swedish minister, and a keen naturalist. Ho arrived in Calcutta in the winter of Is76, and called on me one morning at the Museum anxious to collect and explore anywhere. I took bim up, and together with Jard Tweeddale, Dr. John Anderson, Superintendent of the Indian linseum, and JIr. Wood Mason, we fitted him ont with all that was necessury and sent him to Moulmein to collect in Tenasserim, from whenre be returned in Ilay 1877, with an interesting lot of Birds, Mollusca, and Insects, which he was instructed to par particular attention to. Very much material was obtained on the Peak of Moolerit and its ricinity ; of the mollusca be brought back were some rery interesting and valuable species preserved in spirits. I am sorry to say he suffered much from malarial fercr and had to return to Europe, otherwise he was to have been emplojed in some other parts of burma.

Ta. Shun Strtes and Siam Prontier.

Glessula kentungensis, n. sp. woulthorpi, n. sp. yuangmisis, n. sp. feddeni, u. sp. feddeni, var. ineditus, n. sp. perlecis, n. вp.

P'. CLxil. fig. 19

PI. CLAJI. fig. 18.

P1. ("LY1 . fig. 15.

11. CLIII. fig. 14.

Glesbula hitudiginsis, 11. sp.

Loculity. Mong Sing, Siam Boundary (Lt.-Col. R. Woodthorpe, R.E.). 'Yүe. No. 3650 B.M.

Shell elongately turreted; sculpture: smooth, with irregular subdued rilbing. showing stronger and currilinear below the suture, apex quite smooth, faint sculpture on and and 3rd whorls: colour dull ochraceous : spire elongate, Hat-sided, apex rery blunt, 
large: suture well impressed; whorls 9, sides nearly flat; aperture small, orate; columellar margin rery conrex.

Size: maj. diam. 5.0 ; length $30.25 \mathrm{~mm}$.

This species was also foumd on the Jiekong liver, paler in colour, with an asly tint. No. 3748 B.M.

Glessula woodthorpei, v. sp. (Plate CL.II. fig. 19.)

Locality. Shan States. Nine specimens (Lt.-Col.R. Woulthorpe). Type. Tn. 16 ¿’s B.II.

Shell oblong conoid, shiny, rery smooth; sculpture: distant, ruther coarse indistinct irregular strix; colour olivaceous: spire elongately conic, apex blunt; suture mell impressed; whorls 7 , gradually increasing, body-whorl to length 100 : 5e 5 : aperture ovate, vertical; peristome onter tip thickened; columellar margin slightly concare, short, strong, truncate.

Size : maj. diam. $5 \cdot 75$ : leugth $13 \cdot 5 \mathrm{~mm}$.

This shell lias a likeness to $G$. crassilub, $i s$, but the aperture is smaller in proportion to the leugth; it is not so pointed in the spire, aud the seulpture is different.

A specimen (Hleached) No. 3655, is from the Siam N.IT. boundary.

Glesscla feddexi, m. sp. (Plate CLIII. fig. 15.)

Locrtity. Slian Hills ( $1{ }^{\top} m$. Blanforlcoll.). 'Iype. No.261.06.2.2.

Whell elongately conoid, tumid, rery glassy; sculpture: rather distant striation. closer and stronger on the apical whorls; colour rich ochre: spire conic. 1latly convex, apex blunt; suture impressed ; whorls 7 , sides courex, the last rery ample; aperture oval; peristome outer lip thickened; columellar wargin short, with considerable convexity.

Size: maj. diam. 675 ; alt. axis $13.2 \mathrm{~mm}$.

$$
\text { ," } 6.0 ;, \quad, 14.5 \mathrm{~mm} \text {. }
$$

This is the sliell Blanford reters to as prerlaps distinct from crassilubris, Renฯ.. J. A. A. B. Intjo, p. 95; it mnch resembles that epecies, lint placed side by side the points of viriation are readily seen. Another single specimen (To. $\$ 1.116 .33$.) occurs in the lilanford collection, much more slender in form, but with similar sculpture, which l consider a rariety (Plate CLIIII. fig. 14).

Guassula inedites, n. sp.

Locality. Shan Hills. Threo specimens not named (II. T. Blanfurl collection). Type. No. 83.06.5.5.

shell oblong turieted; sculyture: transcerse close regular raise striation, embryonic whorls smooth: colour: the tyje and hest prenerved rich ochraceous on last whorl: spire elongate, sides flat ; suture impressed; whorls $\bar{T}$, regularly increaning, slightly conrex; aperture orate, small; peristome outer margin thickened; columellar margin short, terminating abruptly.

size : maj. duam. 4.5 ; alt. axis $9.5 \mathrm{~mm}$. 
This specics was found quite recently (July 1919) in a pill-box labelled "shan Hills," tozether with another rery distinct species and a Bithynia, July 1919. It thus remained unsorted and unnoriced for so many years, until my attontion was called to the Mollusca of the Sulween Vulley.

Glessula perlevis, 12. sp.

Locality. Shan Hills, five specimens (2 mature) (W.T. Blanford cullection). Typo. No. 89.06.5.6.

shell ovately oblung; sculpture: smooth on last whorl, only a trace of transierse striation on other whorls, and distant, highlower, close, spiral striation; colour dull umber-brown; spire short, sides flatly convex, apex rounded, rery blunt; suture iupressed; whon ls 6 , Hatly conrex, last the largest; aperture orite or semicircular, outer margin evenly convex, rertical; peristome outer lip thickened; culumellar unargin short, strong, concare.

Size: maj. diam. 4.75 ; alt. axis $9.5 \mathrm{~mm}$.

'This specles recalls $G$. pergurnsis in its shape and blunt apex, hut $j$ ts colour and great smoothness distinguishes it at once. It probably comes from the Shan States near Mandalay and was collected by Fedder.

Glesgula ruangexsis, n. sp. (Plate Cluxil. fig. 18.)

Locality. Yuang $\mathrm{Ha}$, Siam boundary, only one specimen (Lt.Col. Ir. Woulthorpe).

Shell oblong tureted or conoid; sculpture: strong regular distant strix, approaching costulation; colour ochraceous; spire elongately conic. apex very blunt and rounded; suture impressed; whorts 7 , sides flatly convex, 100 : 47 ; aperture narrowly orate; peristome outer lip thickened; columellar margin very slightly convex, strougly truncate.

Size: maj. diam. 6 ; alt. axis $12.9 \mathrm{~mm}$.

I was atyirst inclined to consider this a rariety of woodthorpei, but it differs in many respects, in the proportion of the body-whor to the hoight, the strong sculpture as comprared with the smootbness and the difference in the aperture. A single bleached shell from the Kentung State (No. 158 B.M.) is near this.

Geesenta tatestriata, Möllendorff.

Loculity. Shan States.

This 1 have never seen. 


\section{Glessula (Rishetia) s dNDERI, n. sp.}

Loculity. Amin Gion, Gowhathi, Assam. Only one example (Seneler Lall Hora). Type in Indian Museum, Caleutta.

shell rery elongately turreted; seulpture: smooth to eye, rather distant striation in low relief, the first two embryonic whorls smooth; eolour pale umher-bromn; spire leng, very regularly tapering, apex fine; suturo well impressed; whorls 14 , siles flatly convex, proportion of last whorl to length, $100: 32.5$; aperture narrowly orate; peristome simple, thin; eolumellar margin coneave, sharply truncate.

Size: maj. diam. $9 \cdot 5$; alt. axis $41.5 \mathrm{~mm}$.

This is a beitutiful and new species, the single specimen is in most perfeet state. Its nearest ally is $G$. baculina, Hy. Blandford, ol Darjiling, eompared with which it differs in its greater length and number of whorls, It to 13, and general tumidity, more convex whorls, with suture more impressed, sculpture not so full, side of spire not se straight and flat, last whorl larger and more swollen.

Compared with $G$. subaculina, G.-A., of the Kliasi Ilills and Somth aintia, another near ally, it differs considerably as tollows: It is much loniger. $1 \pm$ whorls to 12 , length 41 to $34.75 \mathrm{~mm}$.; more alternate with finer apex: tapering very regularly, side of spire quite straight: sculpture far less pronounced: enlumellar margin shorter and with more convexity. Considerable iuterest is attached to the fiuding of this Glessula at Amin Gion. $4(00$ rards frnm the Rialway Station, where sunder Lall of the Indian Mlusem, returniug from Mnnipur, was detained for six hours; he made the best of the opportunity, obtaining at the same time six specimens of another Gilessula, a rariety of sarissa.

Regarding the range of $G$. baculina. it is of interest: 400 miles east of Darjiling, at the base of the Dafia Hills, 450 leet. I tound that $G$. hammetiensis took its place: the apex is more obtuse and the seulpture is rery different from that of Hy. Mlanford's species. It comes from a low elevation compared with Darjiling: Harmutti is some 150 miles east from Gowhathi: 50 miles nortl of that place, near Dewingiri, at the base of the Bhutan Hills. the Datla species, or one very close to it, in all probability is" to be found, indicative of the area and side from which $G$. sunileri was derired. The intrusive granite at (iowbathi extends thence for some distance north, exposed and rising at intervals above the deep allurial of the Bramaputra, which eridently corea's inuch more, pointing to a once close connection of low hilly country, by which land-rollusea could trarel far out into the plain of Assam. Such former eonnection with the Assam liango or the Khasi and Faro Hills is more pronounced between Gowhathi and Dubri, trending towards the sreat mass of granite of Gipmochi Peak into the Western Bhutan IFills (see also page 11). 
I have not hitherto seen any elongate Glessula (Rishetia) of the baculina type from so low an eleration as Gowhathi (only about 300 feet) and so far from the hase of the eastern Himalaya, all have eome from quite high habitats of $3-5000$ feet. This is not surprising when we cousider that from Growhathi westward up to the Garo Hills, an area of 135 miles by 32 , or over 4100 sq. miles, no landmollusca hare been collected, until the high ground in the Khasi Hills is reached, where $G$. subbuculine is abundant. Eastward it is the same up to the Mikir Hills, a tract mostly of hill-country, 6t miles long by 32 broad or some 2000 sq. miles. North of the brihmaputrit, for the distance of $190 \mathrm{mlles,}$, another $6000 \mathrm{sq}$. miles, vo collecting has been made. I trust Sunder Lall will before long be given the opportunity of colleeting all along the line of the Assam railway and visit places contiguous to 1t, particularly the isolated low granite hills north of the Brabmaputra liver.

Glessula burrailensis, G.-A., var. maxwelit, G.-A.

Locality. Somra Tracts, Somra Khulen Post, Upper Burma, S.t. 19. About L. $25^{\circ} 20^{\prime}$ N., L. $90^{\circ} 45^{\prime}$ L. No. 3742 B.M.

Shell elongate cylindro-conoid, turreted, solid, rather shining; sculpture: on the protoconch ribbing, approaching fine costulation, merges into finer, more irregnlar, and eurvilinear on the succeeding whorls; just below the suture this sculpture is stronger, giving the appearauce of crenulation; colour a rich vehre, some are chestnut; spire long, gradually inereasing, sides with slight convexity, apex blunt; suture moderatcly impressed; whorls $10 \frac{1}{2}$, flatly convex, the last the largest; aperture oval, rather narrow for size, milky white within; peristome outer margin well thickened, white; columella strong, concave, truncate.

Size: maj. diam. 10.0 ; alt. axis $32.75 \mathrm{~mm}$.

$\left.\begin{array}{c}\text { The longest and } \\ \text { most attenuate }\end{array}\right\} \quad$ " , $9.25 ; \quad, \quad, 33.5 \mathrm{~mm}$.

This very interesting shell was collected by Captain L. R. Mawson, 1st Lushai Hills Battalion, Assam Rifles, and is a more attennate form of $G$. Gurrailensis from the Naga Hills, this easterly locality extending the range to the hill-slopes of the Kyengdwen Valley. 


\section{EXPLAXATION OF PLATE CLIX.}

Fig. 1. Glessula (Rishetia) longispira, n. sp.

2. - - - (- - - , n. *p.

3. - - (-) tenuispira, Bs.

4. - - (-) subaculina, n. sp.

5. - (- ) hamuttiensis, n. sp.

6. - - (- ) rissomensis, n. sp.

7. - - (-) baculina, 11. Bit. ('Ispe).

8. - (- canarctense, n. sp.?

9. - - (-) suliaculina, 11. sp.

10. - - (- munipurense, n. sp.

11. -... (- -) yarvense, n. sp., smiall rar.

12. - (-) stremencolor, n. s].

Rishettclu, Sikhim. $\times 1.25$.

Raslichu, sikhim. $\times 1.50$.

Teria Gihat, Kluasi.

Khasi IIills.

Jafla 11 ills.

1)ansaug, Sikhim.

Ditrjiling.

N. Cinati.

North Kluasi.

$\times$ "

$\times \quad$,

$\times$,

$\times$

$\times 1 \% 5$

Munipur.

$\times 1 \cdots 5$.

$\times 1.50$.

13. - - (- - baculina, II, Bli., var., exilis. Hamsang, Sikhim.

14. - - (- - - , , , ('ype). Rissom l'eak, Sihlim. $x$

15. - - ( - garoezse, n. sp. (Tyle). Garu 11 ills. $\times$ "

\section{EXPLAXATION OF PLATE CLX.}

Fig. 1. Glessula (Rishetia) burrailensis, G.-1.

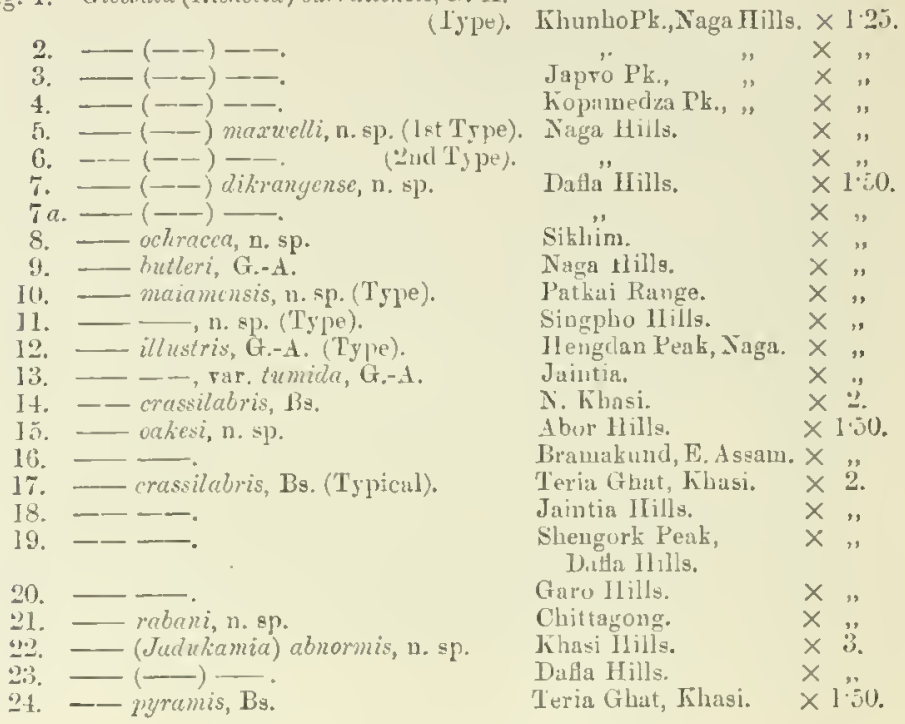

\section{EXPLAYATION OF PLATE CLII.}

Fig. 1. Glessula (Rishetia) pertenuis, W. Blf. Pegu.

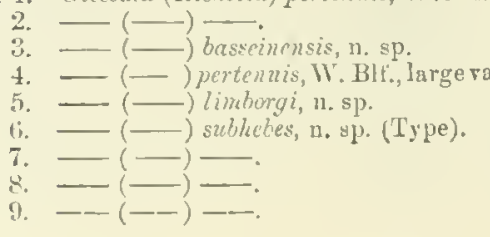

Henzada, Pegu.

$\times 15$

Eassein, ,"

$\times$,

$\times$,

Thyetmyo.

Teuasserim.

Dafla II ills.

Niga.

$\times$,

$x$.

Assain.

$\times 1.5$.

Kotuliagur,

near l'ezpur, dsans. 
Fig. 10. Crlessula (Rishetia) sarissa, Bs.

Lower Bengal.

$\times 2$.

11. - (- nevilliana, n. sp.

Datla Hills.

$12 .-(-)--$

13. - (- (-) mastersi, n. sp.

15. - (- - furum, 11. sp.

16. - (- - hastula, Bs.

17. - - (- ) - (Typical).

" " $\quad \times 1$.

,,$\times 3$.

Chittagong. $\quad \times 1.5$.

18. _- (- ) subhatula, n. sp. (Trpe). North lihasi. $\quad$ "

Iy. - - (- - - - var. (Type).

20. - - (- - - , , ",

21. _- (-) shiroiensis, 10. sp.

22. - - (- - n. sp.

23. - (-) lahupaensis, n. sp.

24. — (-) kohimaensis, n. sp.

25. - (-) Ihataensis, n. sp.

26. - - (sub-genus?) $\left\{\begin{array}{c}\text { gemma, Bo. } \\ \text { 27. }\end{array}\right.$

29. - $\quad$ -

Müuipur.

"

Nag"a Hills.

Whota, Naga Hills. $\quad \times$,

Kloostia, Bengal. $\times$ "

Bengal (authentic). $\times$,

Clsandasagur.

Ohittagung.

$\times$

\section{EXPLAXITION OF PLATE CLXII.}

Fig. 1. Glessula (Rishetia) mastersi, n.sp.(Type). dssam.

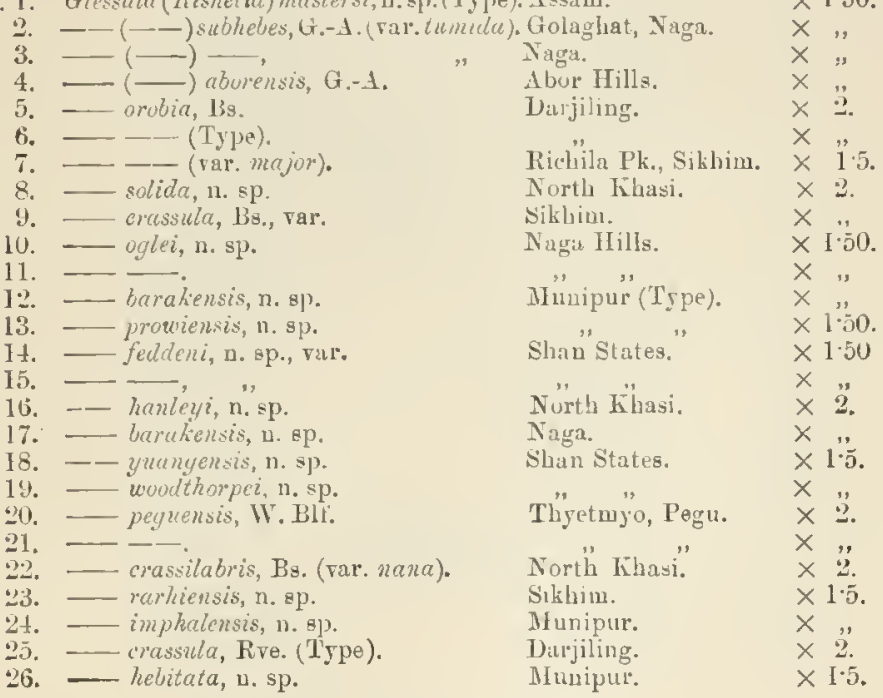

\section{EXPLANATION OF PLATE CLIIII.}

(Enlargements of original Drawings.)

Fig. 1. Glessula botellus, Bs.

2. - nakesi, G.-A. (Type).

3. - botellus, Bs, of I'retston.

4. - - prowiensts, 11. sp. (orobia. Beddome).Naga IIïls.

5. —_ubjerdoni Bedid.(

6. - - -

7. jerdoni uf Nevill).

Tinnevelly llills.

Golcondat. $\times 125$

$\times$,

$\times$,

$\times n$

$\times n$

$\times \quad "$

$\times$ " 
Fig. 8. Glessula orobia, Bs.

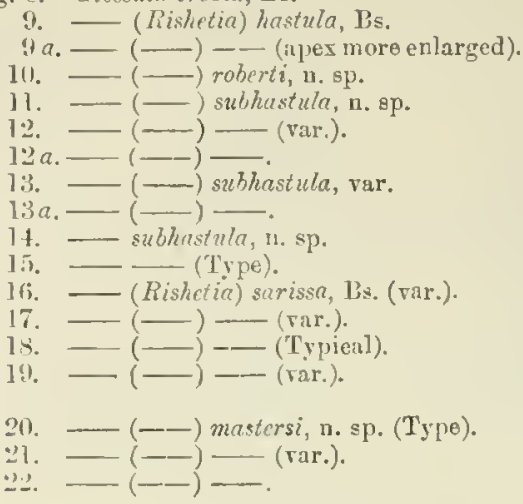

Darjiling.

"

Rieliila, Sikhim.

North líhasi.

North Cachar.

M"üipur."

Chërra Poonjee, Thasi. $x$

North Kinnsi. $\times 24$

Burroi Gorge, Data. $\times 12 \div$.

Gowhatbi.

Jessore.

lioliaghur, Tezpur, $x$ " Assim.

Golaghat, Assam. $\times$,

Augaolno $\mathrm{Pk}$, Naga. $\times$,

Golugliat, Assam. $\times$,"

\section{EXPLANATION OF PLATE CLXIV.}

(Original drawings all $\times 12.5$ and redueed $\frac{1}{4}$.)

Fig. 1. Glessula subhebes (Type).

3. $\square \frac{}{3}$ austenian

$5 . \quad($ L

6. - $(--)-($ small var.)

7. - (-) macera, W. Lif. MS. ('Ty,

8. - muipurensis (Type).

9. - prowiensis.

10. - (Rishetia) pertenuis (large var.).

11. - $(-)-$

1:. - (- - basseinensis, n. sp.

13. - crassula (large var.).

14. - - (Typieal).

15. - - (var. with incised lines).

16. crassilabris, Bs.

17. - - -

18. —— (small var.).

19. - ponsiensis, n. sp. pyramis (rar. major), Nerill. Ponsee, Tunnan.

20. - blanfordiana (Type), $\times 12$.

21 . - - $\times 12$.

2:3. - pegnonsis, W. Blf.

23. - pyramis, Bs.
Dafla Hills.

A bor Hills.

Dafla.

Sonari Tea Garden, $\boldsymbol{A}$ ssam.

Garo 1Iills.

Cachar.

Assam.

Munipur.

Naga 11ills.

Thyetmyo, Pogu.

l'egu.

Bissein, Pegu.

Darjiling.

Rarb̈ichu, Sikhim.

Teria Gliat, Kluasi.

Dafla Hills.

Naga Hills.

Bama, Burma.

Arakan.

Teria Ghat.

\section{EXPLANATION OF PLATE CLXV.}

Glessula (Rishetia) longispira, n. sp. Risetehu, Sikhim.

Fig. 1. Aperture, witb foot protruding, $\times 8$.

$[r d l-l d l$, right and left dorsal lobes. $c p$, fleshy eolumel]ar pillar upon and around which the columellar margin is built. $s$, peristome.]

1 a. Generative organs, $\times 4.5$.

1 b. Penis of 2nd specimen esamined.

1e. The visceral sac, showing coils, buck and front vicrs. 


\section{Glessula ochracea, G,-A. Sikhim.}

2.1. A perture with foot protruding, shoxing sole of foot, $x 4$.

D. Buccal mass, with intestine and salivary glands, $\times 8$.

3 C. Genitalia nearly cumplete, $X+5$.

\section{Glessula oakesi, G.-A. Abor Hills.}

3A. Side of foot, $\times 6$.

$3 \mathrm{~B}$. Albumen gland, bermaphrodite duct, and oviduct to ras deferens, $\times 6$.

$3 \mathrm{C}$. Vas delerens to penis, $\times 6$.

$3 \mathrm{D}$. " " another view, $\times 6$.

\section{Glessula orobia, Bs.}

4. Generative organs, $\times 8$.

ta. Penis, with lagellum, $\times 12$,

46. " ancther viow, $\times 8$.

Glessula inomata, Pfr.

5. Part of genitalia, $\times 45$.

5 a., another riew, $\times 45$.

56 . Penis, coiled view of, $\times 4 \cdot 5$.

5c. Jaw, $\times 24$.

Glessula garuense, n. sp. Silchar, Cachar.

6. Penin, with simple flagellum, $\times 12$.

$6 a$. Spermatheca, $\times 12$.

$$
\text { Glessula species ? Buddula, Ceylun. }
$$

7. Penis, to show flagellum, $\times 8$.

$7 a$. view of other side, $\times 8$.

76 . Follicles of the prostate, $\times 24$ 




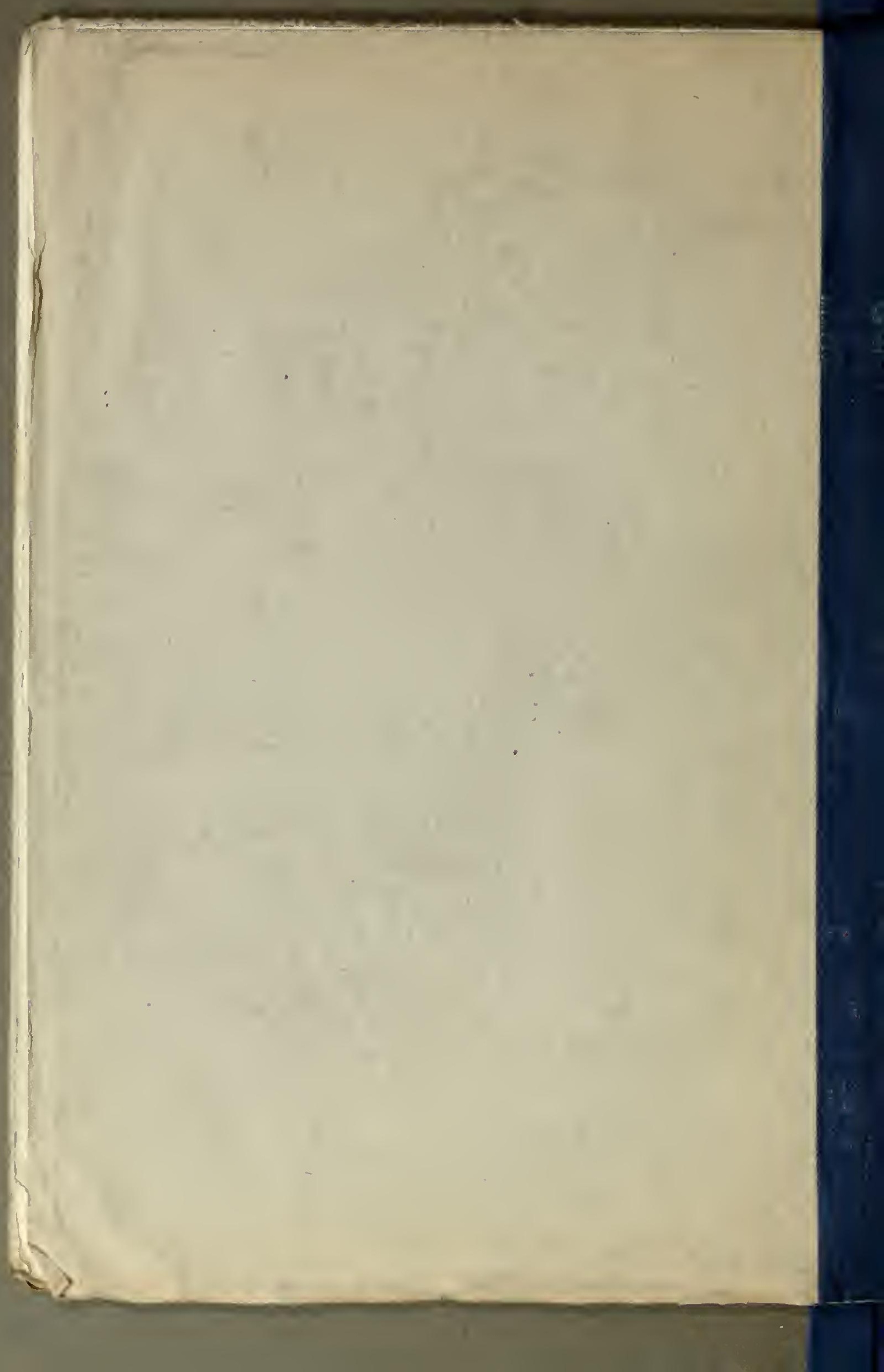




\title{
LAND AND FRESHWATER MOLLUSCA
}

\author{
OF \\ I N D I A,
}

INCLUDING

SOUTH ARABIA, BALUCHISTAN, AFGHANISTAN, KASHMIR, NEPAL, BURMAH, PEGU, TENASSERIM, MALAY PENINSULA, CEYLON, AND OTHER ISLANDS OF THE INDIAN OCEAN.

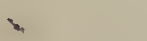

$-$

SUPPLEMENTTARY TO MESSRS. THEOBALD AND HANLEY'S

\section{O N C H O L O G IA I N D I CA.}

BY

LieuT.-Colonel H. H. GODWIN-AUSTEN, F.R S., F.R.G.S., F.Z.S., \&c., LATE DEPUTY SUPERINTENDENT TOPOGRAPHICAL SURVEY OF INDIA, IN CHARGE OF tII KHaSi, Garo, AND NaGa-HILLS SURVEY Partr.

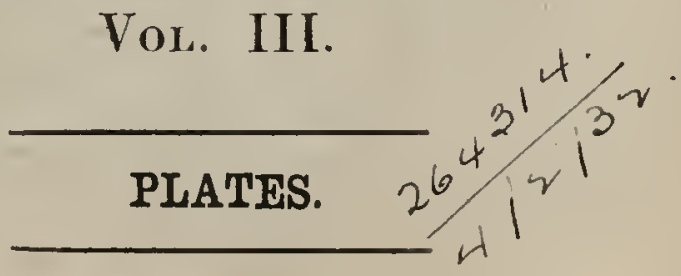

L ON DON :

TAYLOR AND FRANCIS, RED LION COURT, FLEET STREET. 1920. 

$\therefore 1=11$ 
Plate CLIX.
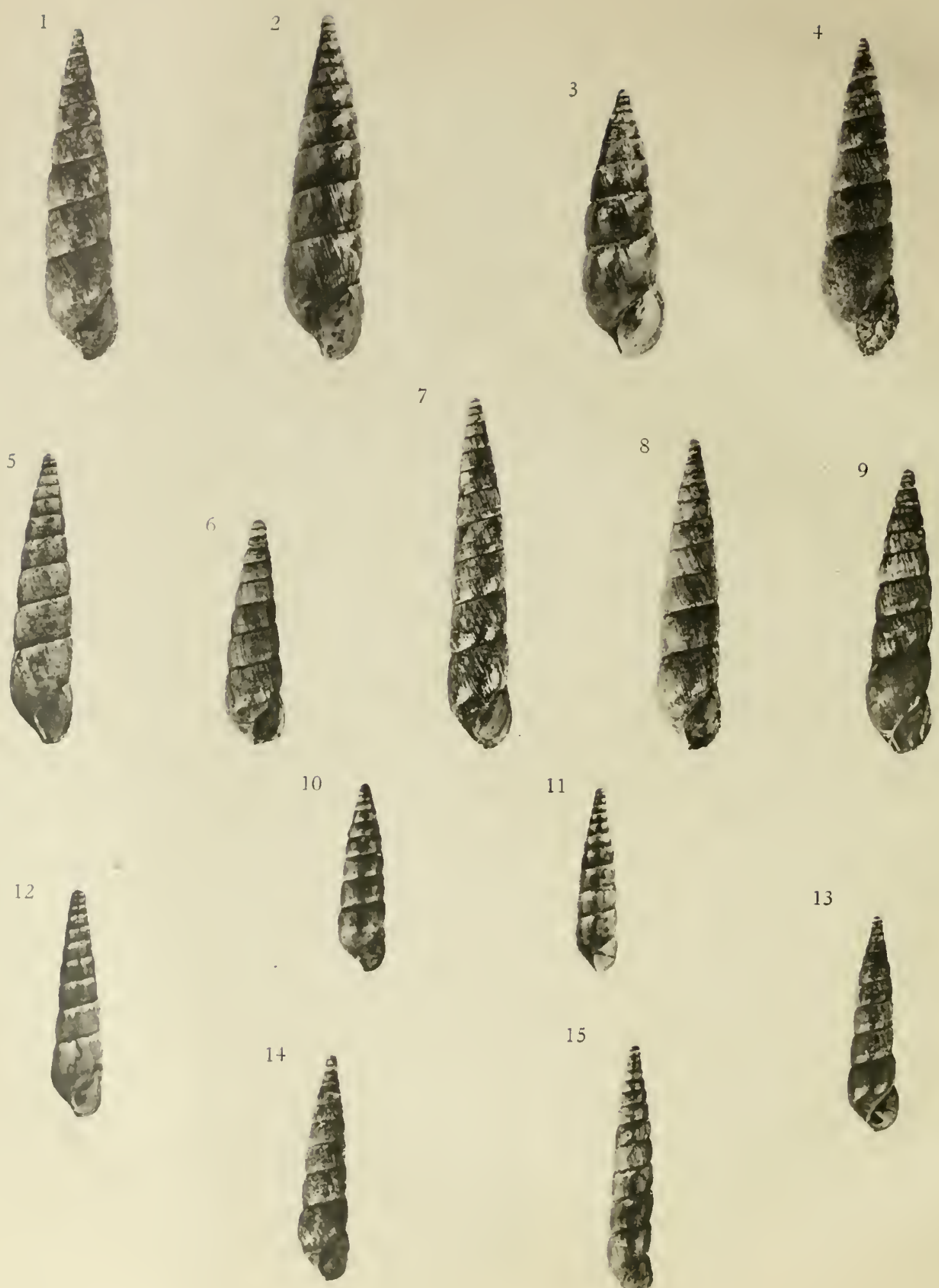

13

15
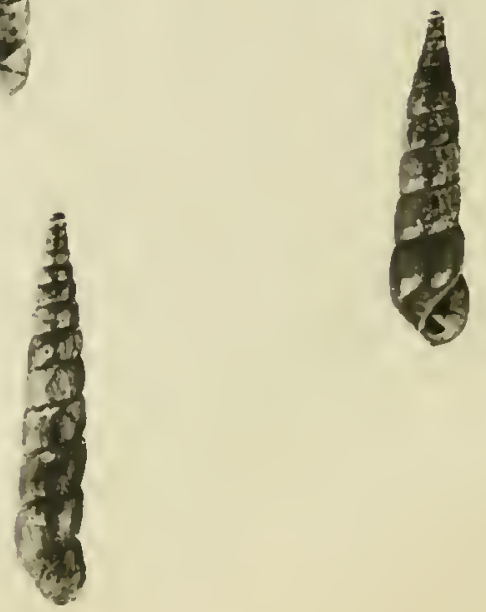


\section{PLATE CLIX.}

[Part I. - November 1920.]

Fig. 1. Glessula (Rishetia) longispir $A$, n. sp.

2. - - ( $(\longrightarrow)-, 11 . \mathrm{sp}$.

3. - - (-) TENUISPIRA, Bs.

4. - - (-) subaculina, 11. sp.

5. - (- (-) HaRMUTTIENSIS, 11. sp.

6. - (-) RissouENS1s, 11. sp.

7. - (-) вaculina, H. Blf. (Type).

8. - (-) CANARAENSE, 11. Sp.?

9. - (-) SUBACULINA, 11. sp.

10. - - (-) MUNiPURENSE, n. sp.

11. - - (-) GAKOENSE, 11. sp., small var.

12. - (-) STRAMENCOLOR, n. sp.

13. - (-) Baculina, H. Blf., var. Exills.

1 t. - - (-) - , , , (Туре)

15. - (-) Garoense, H. sp. (Type).
Rishettehu, Sikhim. $\times 1.25$.

Raslichu, Sikhim. $\times 1.50$.

Teria Gluat, Khasi. $\quad \times$,

Khasi Hills.

Dafla Hills.

Damsang, Sikhim. $\quad \times$

Darjiling. $\quad \times 1.5$.

N. Canara. $\times 1.25$

North Khasi. $\quad \times 1 \cdot 50$.

Munipur.

Naraindhur, Cachar.

Naga Hills. $x$,

Damsaug, Sikhim. $\quad \times \quad$,

Rissom Pcak, Sikhim. $\times$,

Garo Hills. 


Plate CLX.

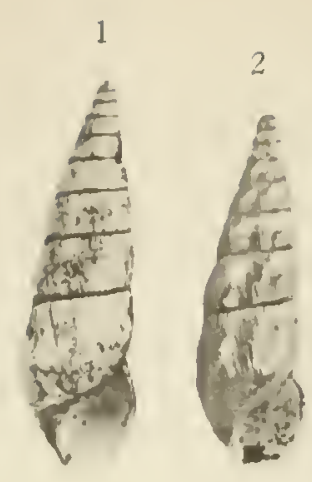

5
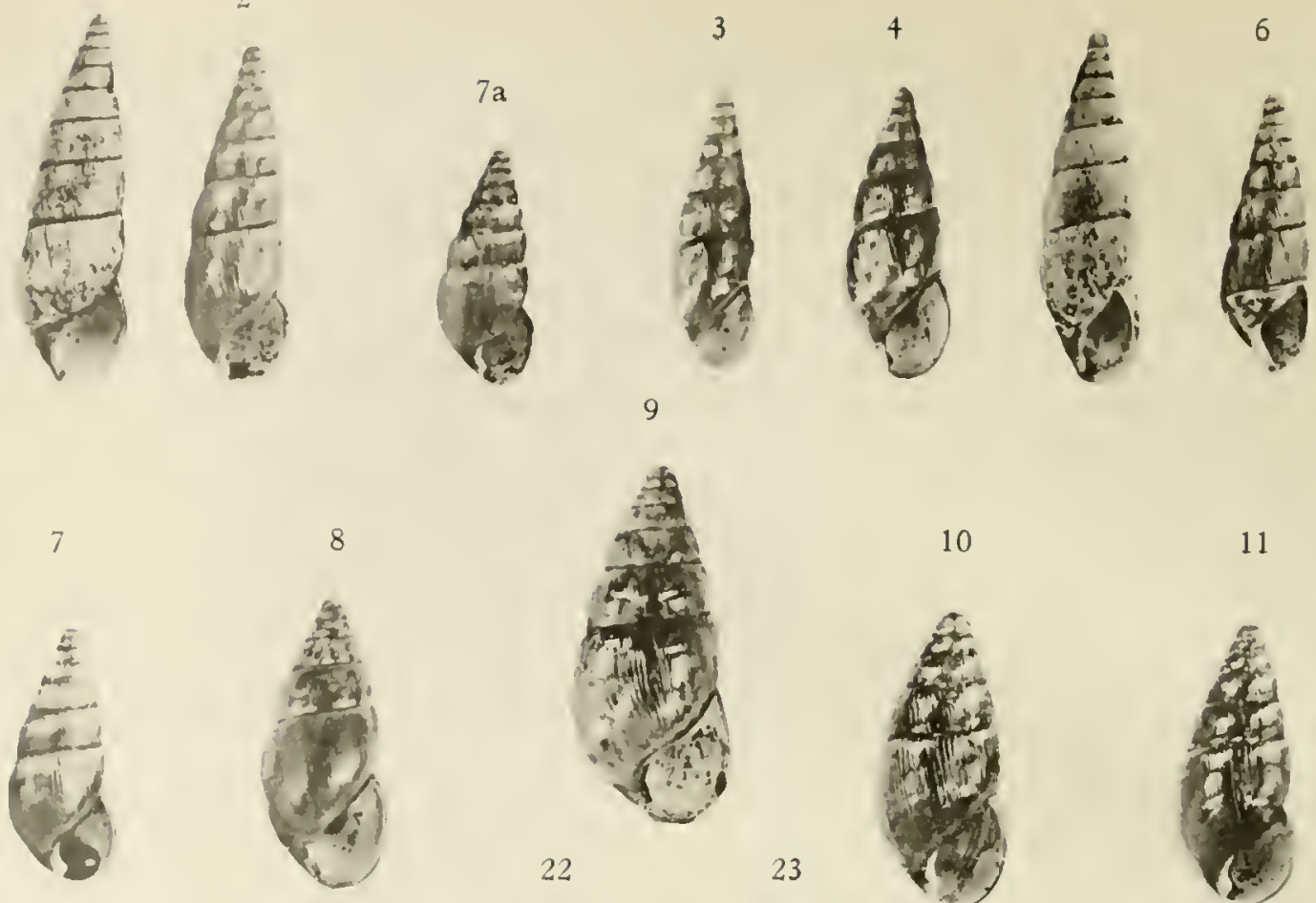

22

23

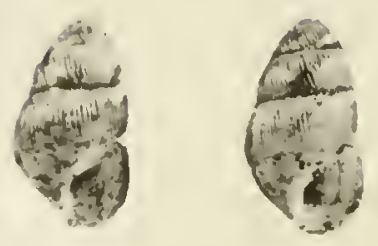

10

11

12

13

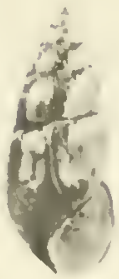

14

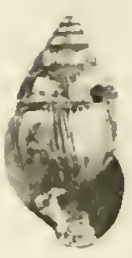

19
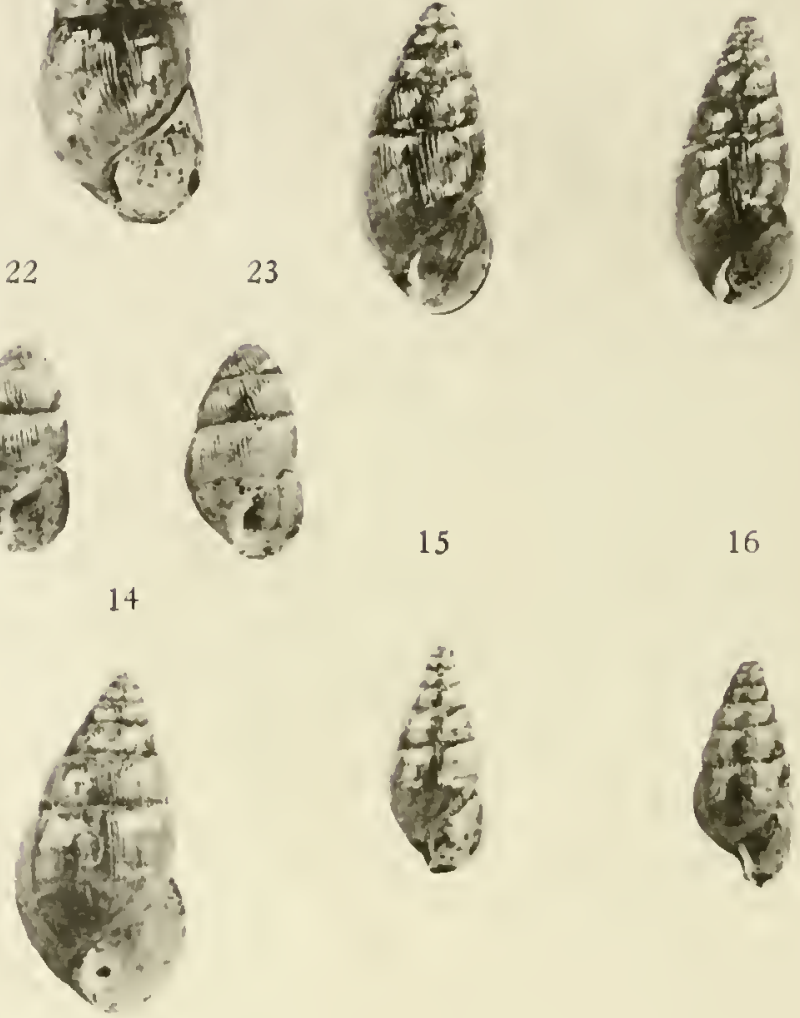

15

16

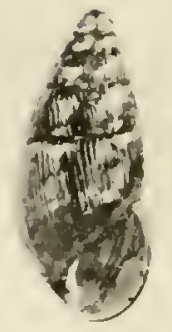

17

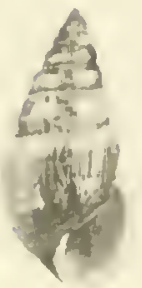

18

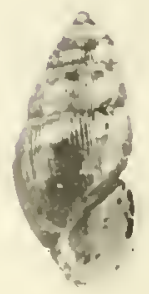

20

24
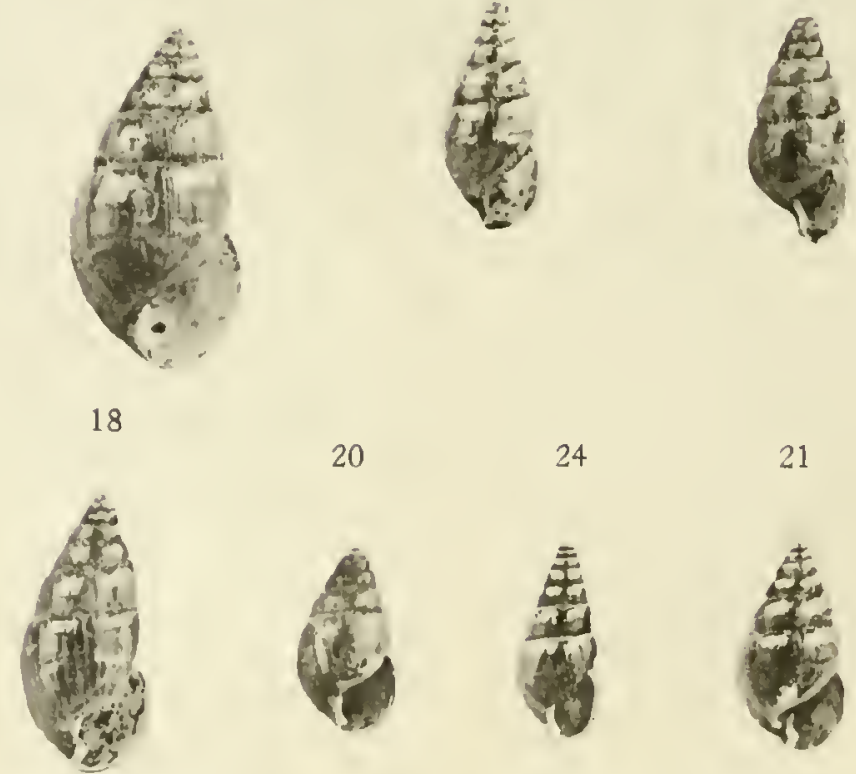

21

GLESSULA.

Watford Eneraving Coy. Collotype. 


\section{PLATE CLX.}

[Part I.-November 1920.]

Fï. 1. Glessula (Rishetia) burrallensis, (i.-A.

(Type). Klmuho Pk., Naga Hilıs, $\times 1.235$.

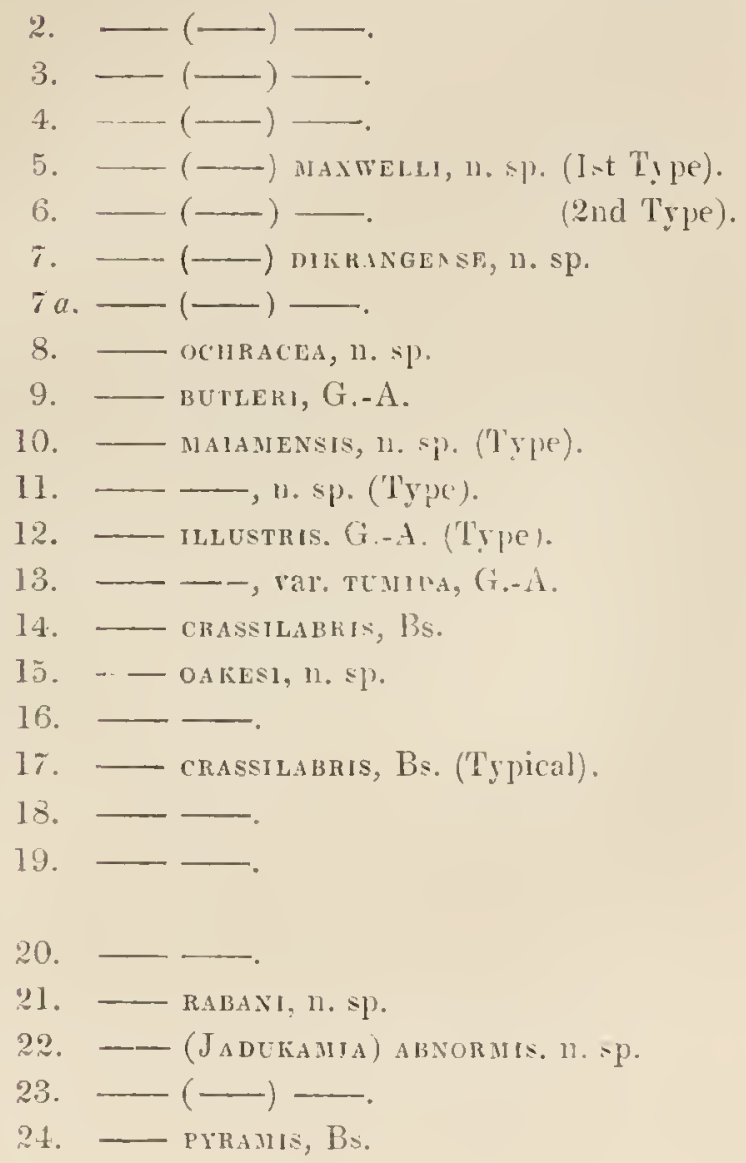




Plate CLXI.
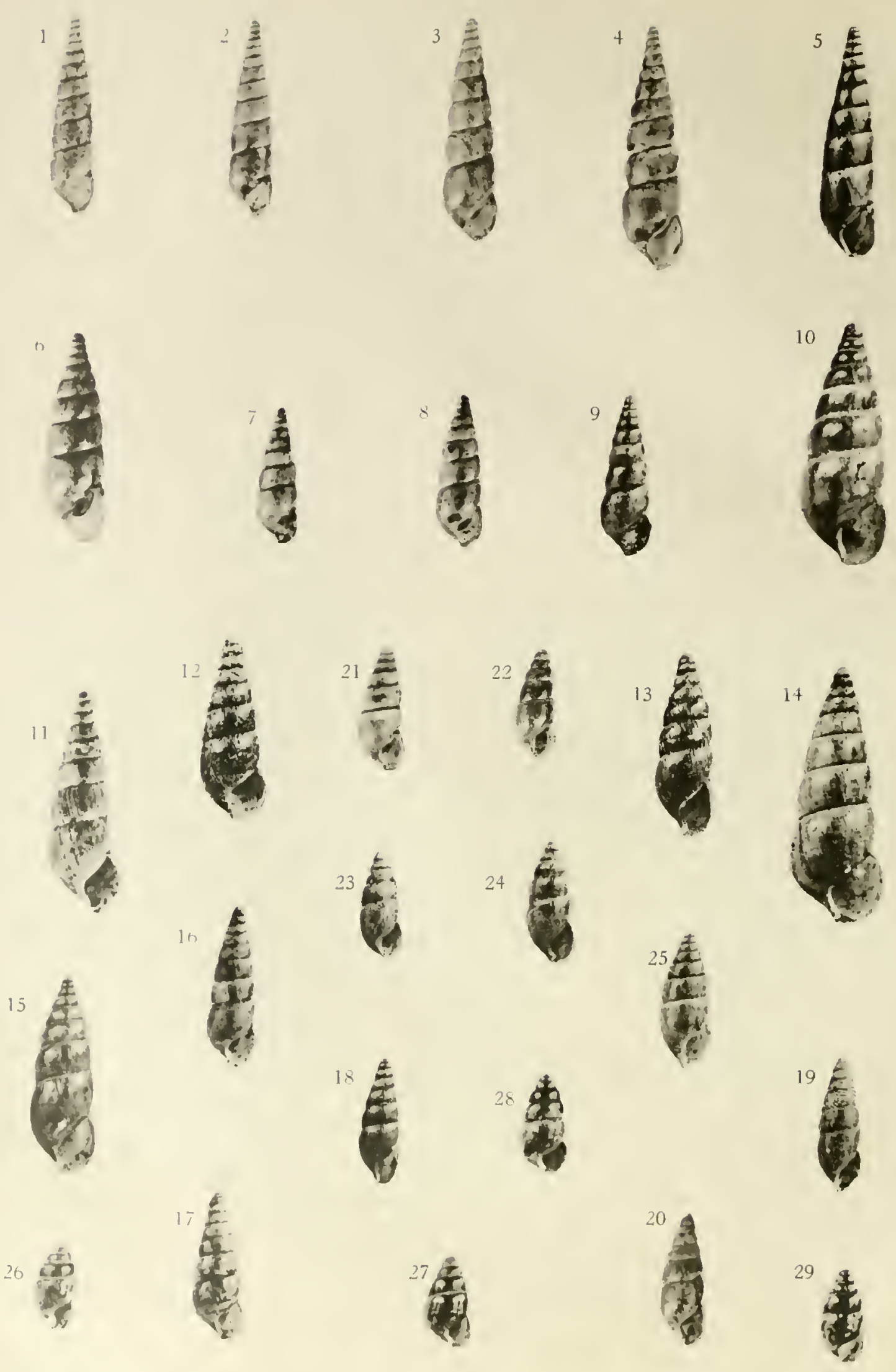


\section{PLATE CLXT.}

\section{[Part I.-Norember 1920.]}

Fig. 1. Glessula (Risuetia) pertenuis, IT. Bif. Pegu.

2. - ( -

3. - (- Basseinexsis, n. sp.

4. -- (- (-) pertenuis, IV. Blf, large val.

Henzada, Pegu.

Bassein, ,

5. - - ( - Linborgi, n. sp.

6. - - ( - subiebes, n. sp. (Type).

7. $-(-)-$

8. $-(-)$

9. $-\cdots(-)$

Thyetmyo.

'Tenasscrim.

Dafla Hills.

Naga.

Assam.

Kohliagur, near 'Tezpur, Assam.

10. - (-) SARISSA, Bs.

11. - (-) NEVILLIANA, 11, sp.

12. - - ( - $)$.

13. - $(-)-$

14. - (-) MASTELSI, n. sp.

15. - (-) FORUM, $\mathrm{n} . \mathrm{sp}$.

16. - (-) HASTULA, Bs.

17. - (- $)$ - (Typical).

18. - (- ) subiastula, n. sp. (Type).

19. - - (-) - var. (Type).

20. - (-) - , , , ,

21. - (- SIIIROIENSIs, n. sp.

22. - (一), n. sp.

23. - (-) LaHUPAENSIS, n. sp.

24. - (-) Kolima ENsis, n. sp.

25. - (-) LIIOTAENSIS, 11. sp.

26. -

Lower Bengal.

Dafla IIills.

$$
\begin{aligned}
& \text { ", } \\
& \text { ", }
\end{aligned}
$$

Chittagong.

Darjiling.

North Khasi.

27. - (sub-genus ?) , ,

28. - -

29. -

M"mipur.

"

,

Naga Hills.

Lhota, Naga Hills.

Khoostia, Bengal.

Bengal (authentic).

Chandanagur.

Chittagong. 


Plate CLXII.

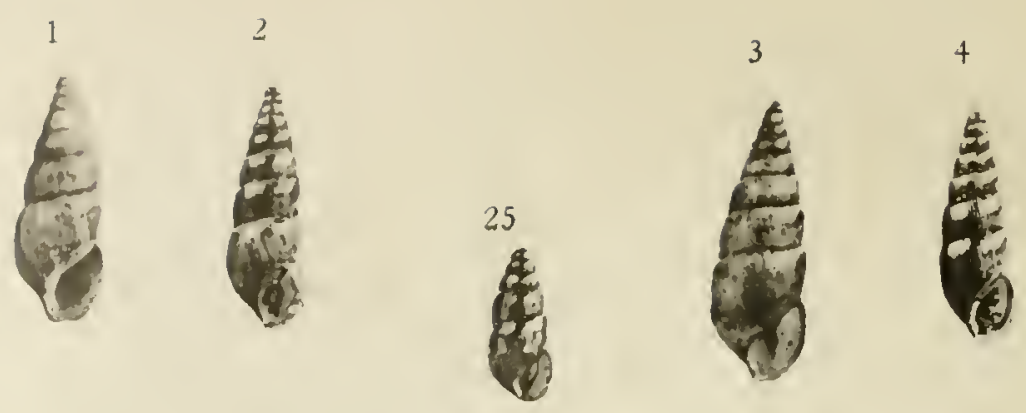

5
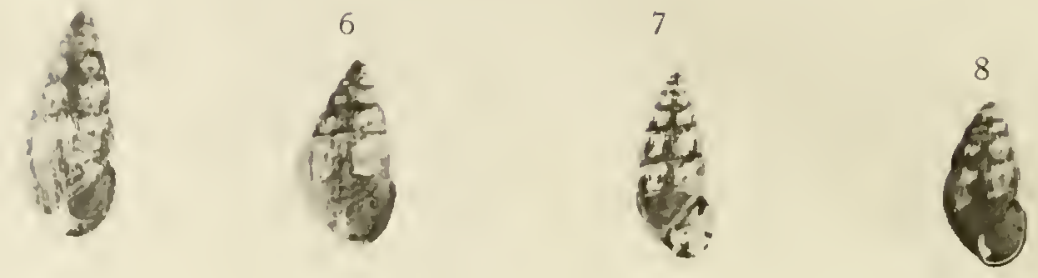

9

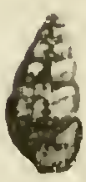

12

13
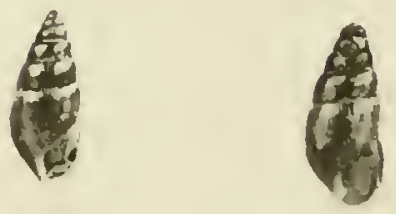

16

17

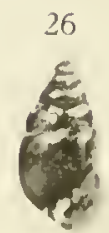

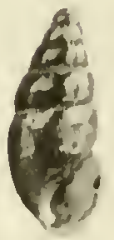

23

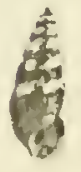

20

21

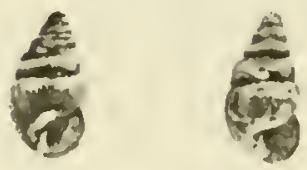




\section{PLATE CLXII.}

\section{[Part I.-November 1920.]}

Fig. 1. Glessula (Risietia) mastersi, 11. sp. (Type). Assam.

$\times 1 \cdot 50$

2. - (-) subiebes, G.-A. (var. tumina). Golaghat, Naga.

3. - ( - -

4. - (-) aborensis, G.-A.

5. — orobia, Bs.

6. - (Type).

7. - - (var. MAJOR)

8. - - SOLIDA, n. sp.

9. —— crassula, Bs., rar.

10. — OGLEI, n, sp.

11 . - -

12. - - BARAKENSIS, 11. sp.

13. — Prowiensis, n. sp.

14. —— FEDENI, 11. sp., var.

15. - - - ,

16. —- IIANLTYI, n. sp.

17. - - BARAKENSIS, 12 . Sp.

18. - - YUANGENSIS, 11. sp.

19. - - WOONTHORPE, 11. sp.

20. —- PEGUENSIS, W. Bit.

21. ————.

22. - Crassilabris, Bs. (var, nana).

23. —— Rafhitensis, n. sp.

24. — JMPHALENSIS, II. sp.

25. - Crassula, Rve. (Type).

26. - - hebitata, n. sp.
Naga.

Abor Hills.

Darjiling.

Richila Pk., Sikhim.

North Khasi.

Sikhim.

Naga Hills.

Munipur (Type).

Shan States.

North Khasi.

Naga.

Shan States.

, "2

Thyetmyo, Pegu.

,

North Khasi.

Sikhim.

Munipur.

Darjiling.

Munipur.

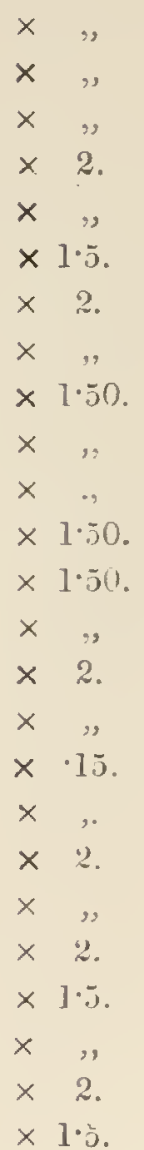

$\times 1 \cdot 5$. 


Plate CLXIII.

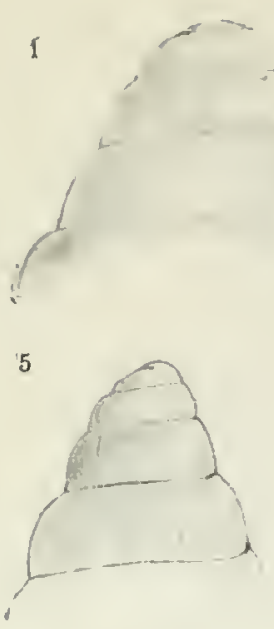

2
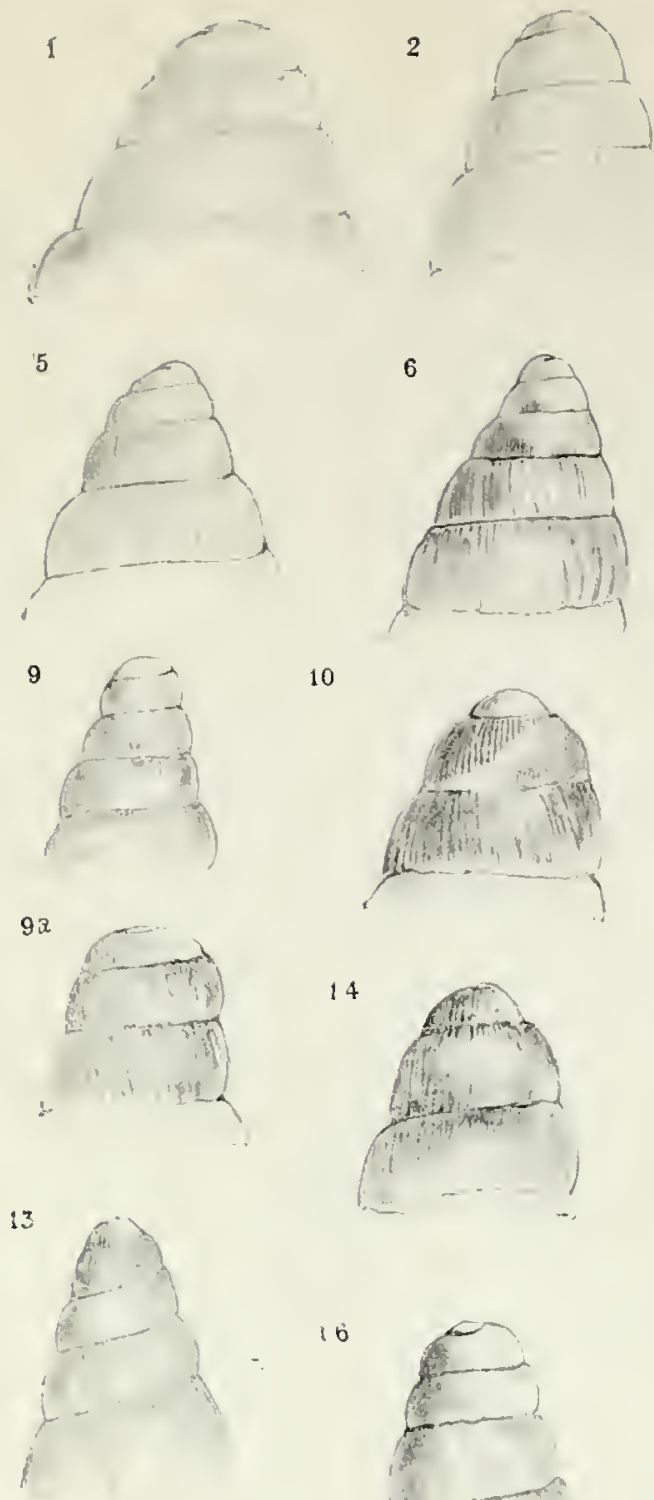

$13 a$

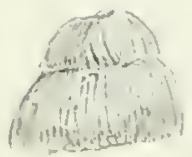

19

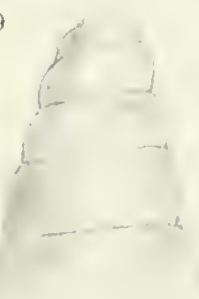

10
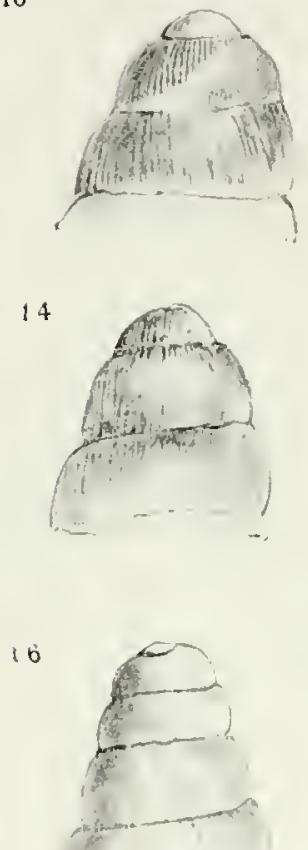

20

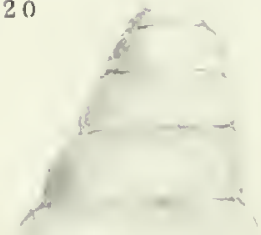

3
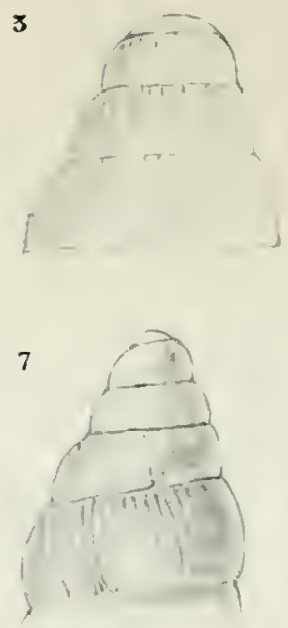

11
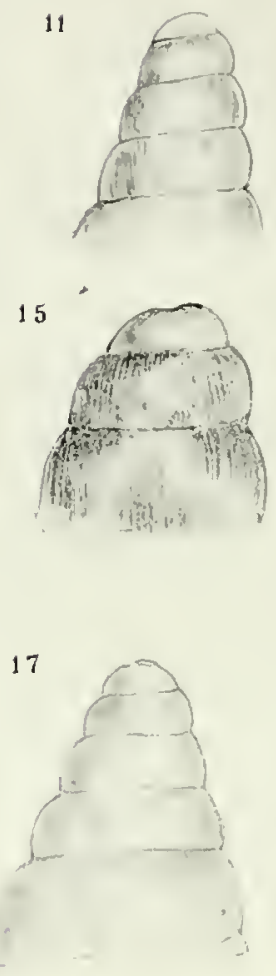

21

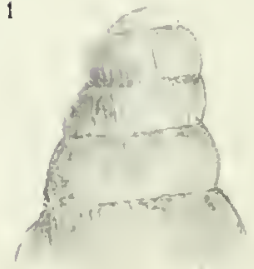

4
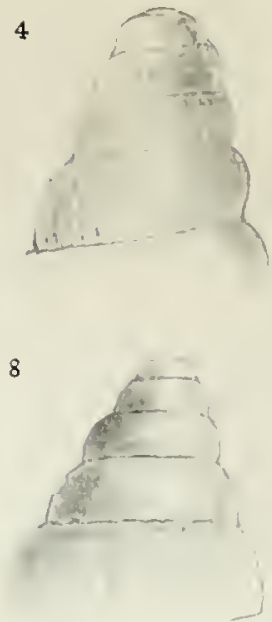

12

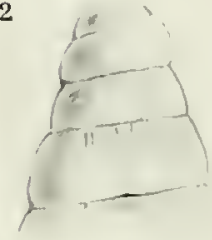

12 a
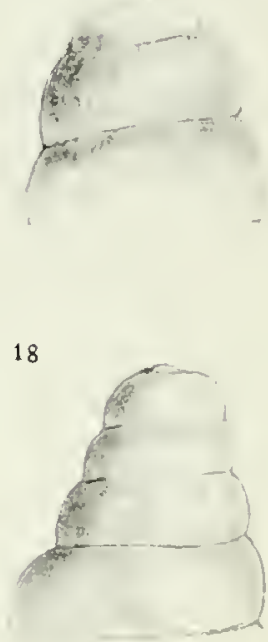

22

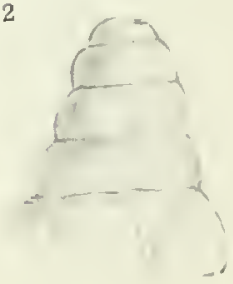




\section{PLA'TE CLXIII.}

\section{[Part I.-November 1920.]}

[Enlargements of original Drawings.]

Fig. 1. Glessula botellus, Bs.

2. - - oAKesi, G.-A. (Type).

3. - Botellus, Bs., of Preston.

4. - - prowiensis, n. sp. (ововia, Beldome).

5. - - subjerdoni, Bedd. (val. minor, subJERDONI of Nevill).
6. - -
7. - - -
8. — ововіА, Bs.
9. - - (Rishetia) inastula, Bs.

9a. - - (- - - (apex more enlarged).

10. - - (一) RовеRTI, n. sp.

11. - (-) subilastula, n. sp.

12. - - (-) - (var.).

12a. - - (-) - -

13. - - (- ) suBinastula, var.

$13 a .-(-)$ -

14. - subhastula, n. $\mathrm{sp}$.

15. - - - (Type).

16. - - (Rishetia) sarissa, Bs. (var.).

17. - - (- - - (var.).

18. -— (-) - (Typical).

19. - - (-) - (var.).

20. - - ( - Mastersi, b. sp. (Type).

21. - (- - (var.).

22. - - (- $)-$
Nilghiris.

Abor llills.

" $"$

Naga Hills.

Jegpur.

Tinnevelly Hills.

Golconda.

Darjiling.

",

"

Richila, Sikhim.

Nortl Khasi.

North Cachar.

Munipur.$$
\text { " }
$$

Cherra Poonjee, Khasi.

North Khasi.

Burroi Gorge, Dafla.

Gowhathi.

Jessore.

Koliaghur, Tezpur,

$$
\text { Assam. }
$$

Golaghat, Assam.

Angaolno Peak, Naga.

Golaglat, Assam. $\times 12.5$.

$\times$,

$\times$,

$\times$,

$\times$,

$\times \quad$,

$\times$,

$\times$,

$\times \quad$,

$\times 24$.

$\times$,

$\times 125$.

$x$,

$\times 24$.

$\times 12.5$.

$\times 24$.

$\times$,

$\times 24$.

$\times 125$.

$\times$,.

$\times$.

$\times$,

$\times \quad$,
$\times \quad$,
$\times \quad$, 


Plate CLXII
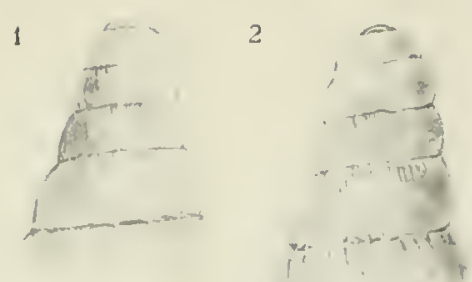

3

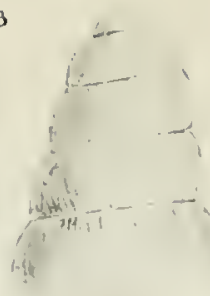

4

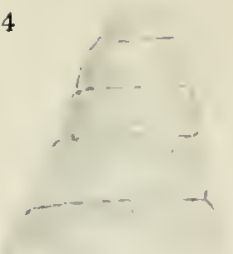

13

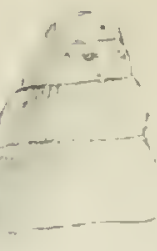

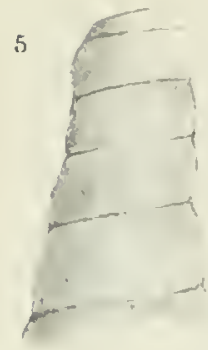
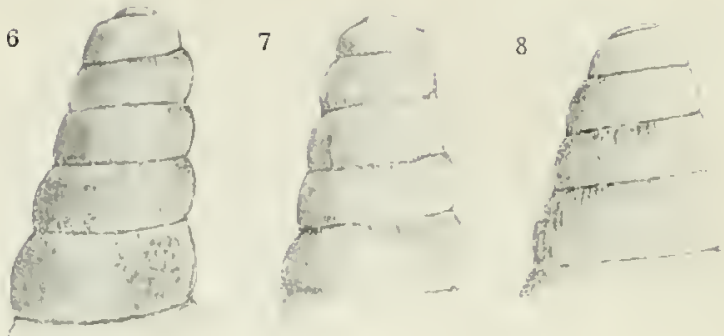

14

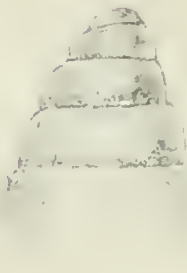

9
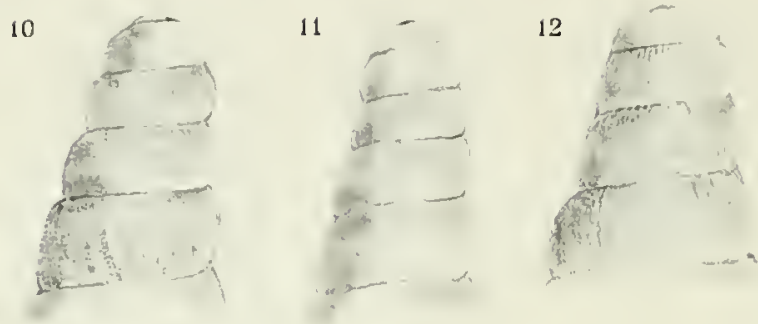

15
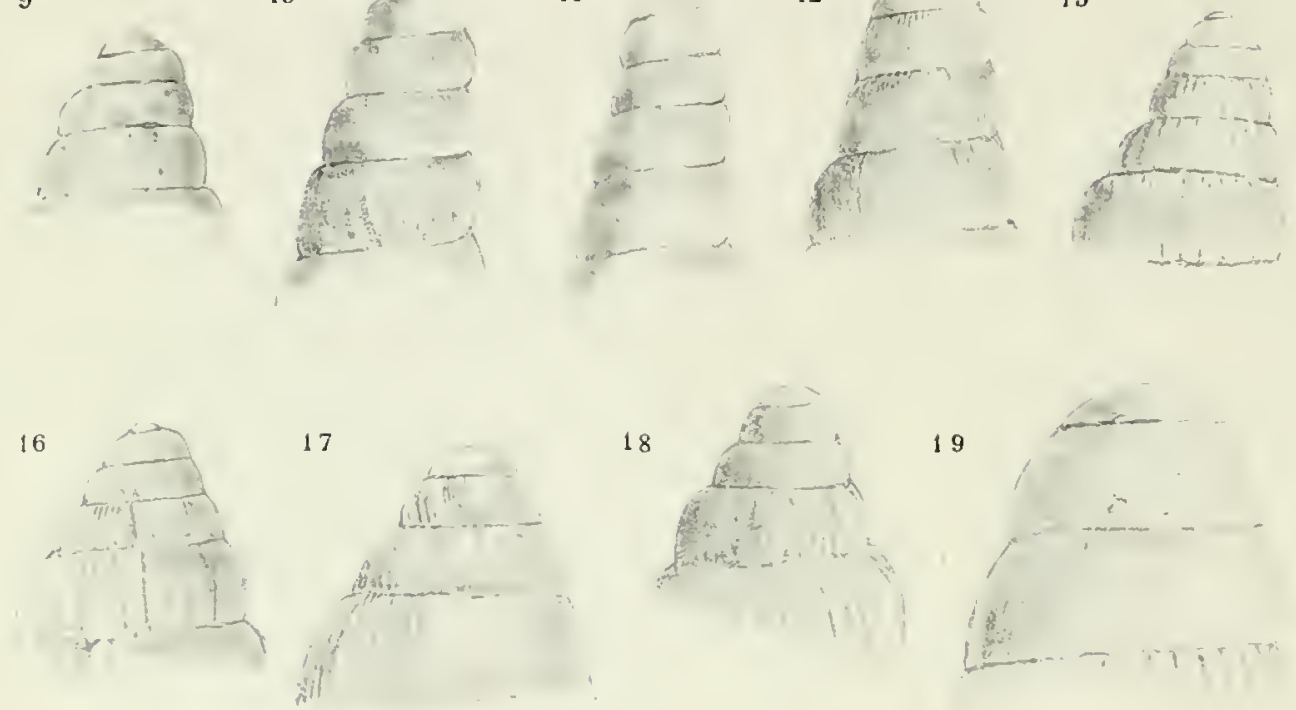

20

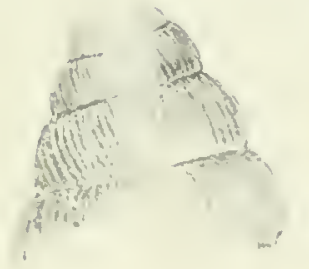

21
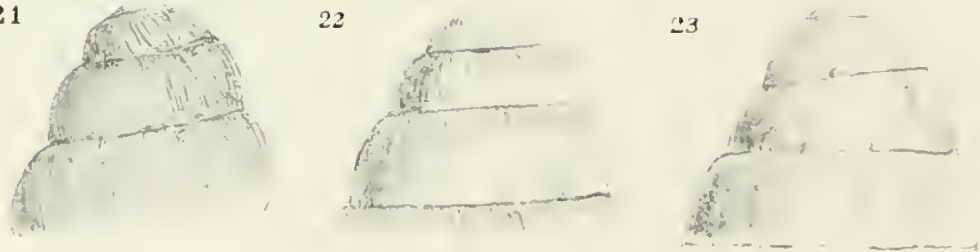

F. W Reader. Sculp 


\section{PLATE CLXIY.}

\section{[Part I.-November 1920.]}

(Original drawings all $\times 125$ and redueed $\frac{1}{4}$.)

Fig. 1. Glessula submebes (Type).

2. - -

3. - austeniana, Nevill (Type).

4. - _ (Rishetia) HIHINGensis, 11. sp.

5. - (—) gakoense, n. sp. (Tуре).

6. - - ( - (small var.).

万. - (-) Maceka, IV. Blf. MS. (Type).

8. — Muxipurensis (Type).

$9 . \quad$ PROWIENSIS.

10. - (Risiletia) pertenuls (large var.).

11. - $(\longrightarrow)-$

12. - (- (-) BasseineNsis, 11. sp.

13. Crassula (large var.).

14. —— (Typieal).

15. - - (var. with incised lines).

]6. Crassilabris, Bs.

17.

18. —— (small var.).

19. —— PONSIENSIS, n. sp. PYRAMIS (var. IIAJOR),

Nevill. Ponsee, Yunuan.

20. — Blanfoldiana (Type), $\times 12$.

21. - - $\times 12$.

22. PEGUENSIs, W. Blf.

23. —_ pYktMis, Bs.
Dafla Hills.

Abor IHills.

Dafla.

Sonari Tea Garden, Assam.

Garo Hills.

Cachar.

Assam.

Munipur.

Naga Hills.

Tisyetinyo, Pegu.

Pegu.

Bassein, Pegu.

Darjiling.

Rarhichu, Sikhim.

Teria Ghat, Khasi.

Dafla Hills.

Naga Hills.

Bawao, Burma.

Arakau.

Teria Ghat. 


Plate CLXV.
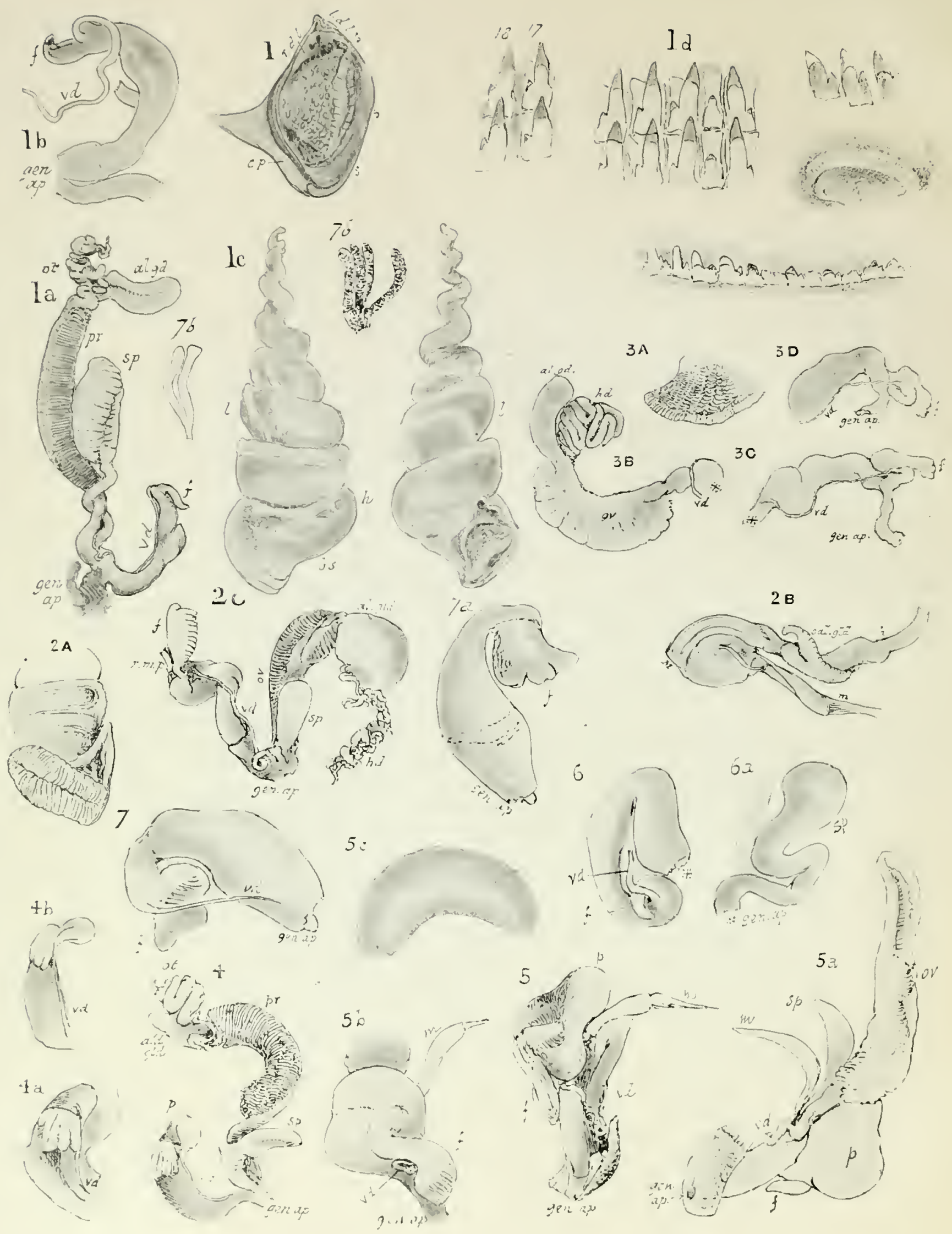


\section{PLATE CLXV.}

[Part I.-November 1920.]

Glessula (Rishetia) longlspika, n. sp. Risetchn, Sikhim.

Fig. 1. Aperture, with foot protruding, $\times 8$.

[rdl-ldl, right and left dorsal lobes. $c p$, fleshy columellar pillar upon and around which the columellar margin is built. $s$, peristome.]

1 a. Gencrative organs, $\times 45$.

$1 b$. Penis of 2nd specimen examined.

1 c. The visceral sac, showing coils, baek and front views.

\section{Glessula ochracea, G.-A. Sikhim.}

2A. Aperture with foot protruding, showing sole of foot, $x+$.

2 B. Buccal mass, with intestine and salivary glands, $\times 8$.

2 C. Genitalia nearly complete, $x+\frac{5}{5}$.

Glessula oakesi, G.-A. Abor Hills.

3 A. Sile of foot, $\times 6$.

$3 \mathrm{~B}$. Albumen gland, hermaphrodite duct, and oviduct to vas deferens, $\times 6$.

$3 \mathrm{C}$. Vas deferens to penis, $\times 6$.

$3 \mathrm{D}$. " " $"$ another view, $\times 6$.

Glessula orobia, Bs.

1. Generative organs, $\times 8$.

$4 a$. Penis, with flagellum, $\times 12$.

4 b. " another view, $\times 8$.

\section{Geessula inornata, Pfi.}

5. Part of genitalia, $\times+5$.

$5 a$. " ",$\quad$ another view, $x+5$.

5 b. Penis, coiled view of, $\times 4.5$.

5 c. Jaw, $\times 24$.

Glessula garoense, n. sp. Silchar, Caehar.

6. Penis, with simple flagellum, $\times 12$.

$6 a$. Spermatheca, $\times 12$.

Guessula species? Buddula, Ceylon.

7. Penis, to show flagellum, $\times 8$.

$\gamma a$. ",$\quad$ view of other side, $\times 8$.

7 b. Follieles of the prostate, $\times 24$. 





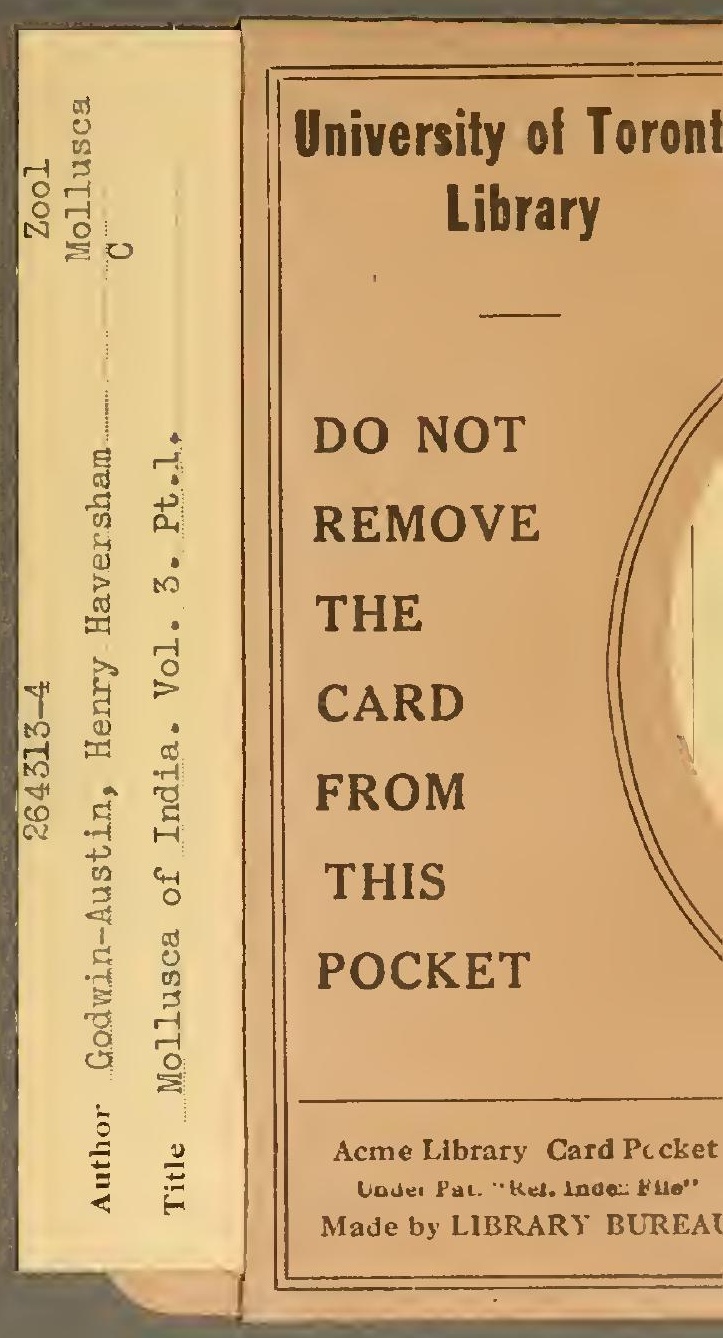


